CENTRO UNIVERSITÁRIO DE BRASÍLIA - UniCEUB PROGRAMA DE INICIAÇÃO CIENTÍFICA

JONHNY HERNANY DE S P LEAL

COMPARAÇÃO DA EFETIVIDADE DO EXERCíCIO RESISTIDO DE FORMA UNILATERAL VERSUS BILATERAL NO TRATAMENTO PÓS-OPERATÓRIO DO LCA CONTRALATERAL

BRASÍLIA 


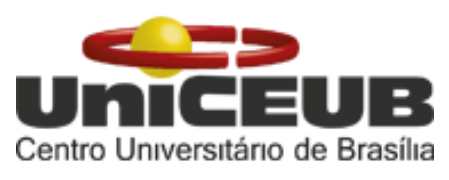

JONHNY HERNANY DE S P LEAL

\section{COMPARAÇÃO DA EFETIVIDADE DO EXERCÍCIO RESISTIDO DE FORMA UNILATERAL VERSUS BILATERAL NO TRATAMENTO PÓS-OPERATÓRIO DO LCA CONTRALATERAL}

Relatório final de pesquisa de Iniciação Científica apresentado à Assessoria de Pós-Graduação e Pesquisa.

Orientação: Márcio de Paula e Oliveira

\section{BRASÍLIA}




\section{RESUMO}

OBJETIVO: Este trabalho teve como objetivo analisar se a estratégia de utilização do exercício resistido isotônico unilateral é mais efetivo do que a forma bilateral para obtenção da simetria do desempenho muscular entre o membro doador e receptor durante tratamento fisioterapêutico na fase pós-operatória do LCA contralateral.MÉTODOS:Foi realizado um estudo clínico randomizado, cego, com 88 pacientes divididos em Grupos Controle ( $N=44)$ e Intervenção $(\mathrm{N}=44)$. Os indivíduos eram de ambos os gêneros, praticantes de atividades físicas em nível recreacional e encontravam-se ao final do $3^{\circ}$ mês de tratamento pós-operatório. Os participantes foram divididos em dois grupos e submetidos a um programa de oito semanas de exercícios resistidos. O Grupo Controle realizou um programa convencional de exercícios bilaterais. O Grupo Intervenção realizou a estratégia de exercícios unilaterais. Anteriormente e ao final do período de intervenção todos os indivíduos foram avaliados quanto à presença de sinais inflamatórios, amplitude de movimento, estabilidade articular objetiva (KT-1000 ${ }^{\mathrm{TM}}$ ), desempenho muscular (Pico de torque e Relação isquiotibiais/quadríceps à $60 \%$ s), funcionalidade objetiva (Single Leg Hop Test e Y Balance Test) e subjetiva (Questionário de Lysholm e Escala de Atividades de Vida Diária).RESULTADOS:Ambos os grupos evoluíram com a intervenção, principalmente em relação à perimetria, amplitude de movimento de flexão, $Y$ Balance Test na direção anterior, estabilidade articular objetiva e questionários funcionais. Ambos apresentaram evolução, porém pode-se observar a predominância do grupo intervenção (unilateral), em relação ao grupo controle (bilateral). CONCLUSÕES: Pode-se concluir que o uso do exercício resistido isotônico unilateral é mais efetivo que a forma bilateral na obtenção de maior nível de simetria do desempenho muscular entre o membro doador e receptor durante a fase pós-operatória da reabilitação fisioterapêutica do LCA contralateral.

Palavras-Chave: Ligamento cruzado anterior. Treinamento de resistência. Traumatismos em atletas. 


\section{Sumário}

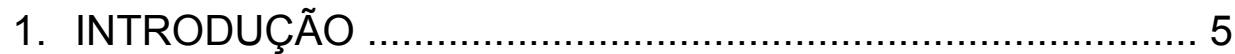

2. OBJETIVOS ............................................................. 5

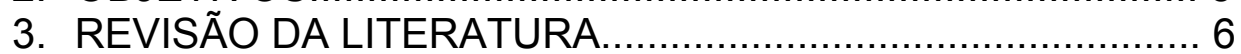

4. MÉTODOS ................................................................. 12

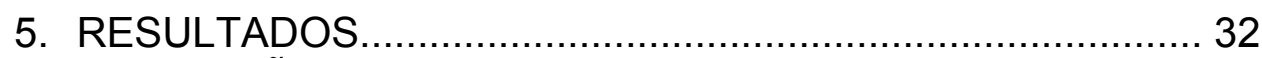

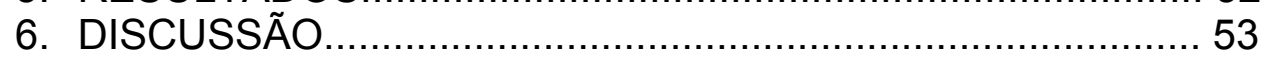

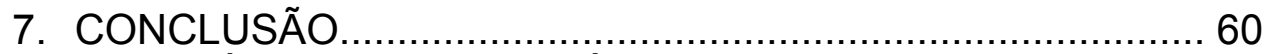

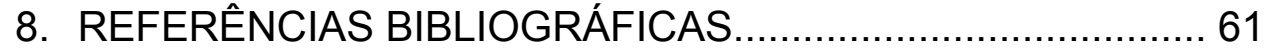




\section{INTRODUÇÃO}

Segundo Moses et al. (2012) e Prodromos et al. (2007), a ruptura do LCA (ligamento cruzado anterior) é uma das lesões musculoesqueléticas mais comuns, e prevalente em esportes coletivos multidirecionais como basquete, futebol, rúgbi, vôlei e futebol americano, ocorrendo com ou sem contato, principalmente entre a faixa etária de 15 a 45 anos. Ainda segundo Moses et al. (2012) todo ano 3\% dos atletas amadores lesionam o LCA, sendo que em atletas profissionais essa porcentagem se eleva para $15 \%$. Além de comum, é também uma das lesões mais debilitantes no esporte devido a sua função de prevenir uma hiperextensão acentuada, rotação e interiorização da tíbia quando em flexão (Perriman et al., 2018). Nos Estados Unidos sua prevalência anual chega a 60 casos por 100.000 pessoas ( Mall et AL., 2014)

Após a lesão completa do LCA o tratamento pode se encaminhar de forma conservadora ou cirúrgica, levando em consideração as características do paciente, atividade física exercida, pretensões quanto a estilo de vida e prática de esportes.

A técnica cirúrgica para reconstrução do LCA consiste na retirada do ligamento rompido e substituição do mesmo por um enxerto que pode ser de origem autógena, alógena e sintética, podendo o enxerto ser retirado da perna ipsilateral ou contralateral. Os enxertos mais comuns são de origem autógena, com menor chance de rejeição e 4 vezes mais chances de re-ruptura ao utilizar enxerto alógeno (Duchman et al., 2017). A escolha da técnica cirúrgica a ser utlizada, origem e tipo de enxerto são de acordo com as características e decisão paciente, habilidade do médico cirurgião e pretensões do paciente quanto a atividades esportivas.

Wright et al. (2011) demonstraram que a chance de uma re-ruptura do LCA em pacientes que se submeteram à reconstrução utilizando o enxerto contralateral é duas vezes maior que nos pacientes com cirurgias ipsilaterais, porém não há como indicar quais são os preditores para uma re-lesão. Embora tenham apresentado esses resultados, Rubinstein et al. (1994) demonstraram que os pacientes que passaram por procedimento utilizando enxerto contralateral apresentaram baixa morbidade por pouco período de tempo e amplamente reversível. Shelbourne (2006) pode concluir que a reconstrução do LCA utilizando enxerto contralateral resultou em menor tempo de recuperação com melhores resultados. No Brasil, Oliveira (2014) e Lobo et al. (2018) confirmaram tais resultados em seus estudos a curto e médio prazo.

Esses resultados permitiram a Shelbourne (2000) a possibilidade de um tratamento fisioterapêutico simultâneo de forma separada, visando uma melhora funcional mais ampla. 
Diante do exposto, fez-se necessário o desenvolvimento dessa pesquisa visando encontrar uma metodologia mais eficaz para aplicação do exercício resistido no pós-operatório da reconstrução do LCA utilizando enxerto contralateral.

\section{OBJETIVOS}

A pesquisa tem como objetivo analisar e comparar a efetividade do exercício isotônico bilateral e unilateral em relação a maior simetria sobre o desempenho muscular entre o membro doador e receptor na reabilitação pós-operatória da reconstrução do ligamento cruzado anterior utilizando enxerto contralateral.

\subsection{OBJETIVO ESPECÍFICO}

Analisar entre os grupos sujeitados ao protocolo unilateral ou bilateral, qual alcançou maior simetria e melhor desempenho muscular em ambos membros após intervenção e com base nos critérios de avaliação prévios ao retorno ao esporte, saber se estavam aptos ou não para retornarem às suas práticas esportivas.

\section{REVISÃO DA LITERATURA}

\subsection{EPIDEMIOLOGIA E FATORES DE RISCO DA LESÃO DO LCA}

A lesão do ligamento cruzado anterior é conhecida como a lesão do jovem que pratica esporte. Em crianças, pelo mesmo mecanismo de trauma, ocorrem os deslocamentos epifisários, já no adulto, as fraturas do platô tibial (Amatuzzi, 2004). Lopes et al. (2016) descreveram a incidência de reconstruções do LCA no Brasil no sistema público de saúde entre janeiro de 2008 e dezembro 2014, investigando as tendências temporais e diferenças entre os grupos de idade e gênero. Um total de 48,241 cirurgias foram reportadas no período, com incidência geral de 3,49 por 100.000 pessoas/ano. $82 \%$ dos procedimentos foram realizados em pacientes homens e o custo total dos procedimentos em todos os anos foi de US\$ 56 milhões. Segundo Maxey (2003) e Costa (2018), as lesões ocorrem principalmente em indivíduos do gênero masculino, como resultado de lesões esportivas. Como o número total de homens nas práticas esportivas é maior, eles estão mais susceptíveis a sofrerem ruptura do LCA. Por outro lado, em atividades nas quais há participação igual de ambos os sexos, com regras e equipamentos parecidos, a probabilidade de uma lesão do LCA é 2 a 8 vezes maior no público feminino (Larson, 1994; Montgomery, 2005).

No que diz respeito à relação entre tipo de modalidade e lesão do LCA, observa-se um maior índice de lesão nos esportes que envolvem saltos, desacelerações na corrida e rotações sobre a articulação do joelho (Dale et al., 1994; Bonfim, 2000), como por exemplo o futebol (Ekstrand et al 2011., Moses et al., 2012). Já os fatores de risco para lesão do LCA podem ser divididos em intrínsecos, 
quando decorrentes de características próprias (congênitas) do indivíduo e extrínsecos, quando envolvem agentes externos.

\subsection{MECANISMO DA LESÃO}

O mecanismo mais comum na lesão do LCA é o trauma torcional. Nesse caso, o corpo gira em rotação externa sobre o membro inferior apoiado no solo. Nesta posição, acentua-se o valgismo do joelho e a lesão do LCA ocorre associada a elementos ligamentares periféricos mediais e dos meniscos, em grau maior ou menor (Amatuzzi, 2004). Outros mecanismos são a força lateral excessiva (estresse em valgo) aplicada na região exterior da articulação, característica em esportes de contato, e a hiperextensão do joelho sem apoio. Esta, conhecida como "chute no ar", pode determinar o aparecimento da lesão isolada do ligamento (Amatuzzi, 2004).

\subsection{TRATAMENTO APÓS A LESÃO DO LCA}

Indivíduos que tenham a lesão do LCA podem ser submetidos a basicamente dois tipos de tratamento, sendo eles a reconstrução cirúrgica do ligamento ou podem ter sua lesão tratada de forma conservadora, isso é, não cirúrgica (Ardern et al., 2017).

Logo após a lesão, deve ser dada atenção prioritária à hemartrose e ao processo inflamatório geral. Os exercícios de mobilidade devem ser iniciados o mais precoce que possível, para possibilitar a restauração da ADM e impedir complicações como fibrose na fossa intercondilar femoral e/ou redução na força do quadríceps (Andrews, 2000). Após o controle da inflamação inicial e restauração da ADM, devem ser iniciados exercícios de fortalecimento muscular do membro acometido (Shelbourne, 1990; Andrews, 2000).

Estudos anteriores apontam que indivíduos com rupturas completas do LCA experimentam uma diminuição na propriocepção, devido à perda do arco reflexo mecanorreceptor do LCA para os isquiotibiais (Lutz, 1990). Segundo o estudo de Andrews (2000), a latência para contração reflexa de isquiotibiais era duas vezes maior que a do membro contralateral. Independentemente da opção de tratamento, os exercícios sensório-motores devem ser trabalhados desde o primeiro momento.

Atualmente, a cirurgia é recomendada principalmente para pacientes jovens ou atletas que perderam a capacidade de executar movimentos bruscos ou aparentemente normais, em decorrência da instabilidade que o joelho adquire após uma lesão aguda ou crônica do LCA (Pinto, 2000). Quando o tratamento cirúrgico é adotado como opção final de tratamento, a escolha do momento certo para o procedimento evita consideravelmente as complicações pós-operatórias (Shelbourne, 1995). Segundo o trabalhdo de Shelbourne (1999), a restauração da ADM completa, redução completa do edema pós-lesão e a melhora do controle neuromuscular do membro são fatores determinantes para a diminuição da 
incidência de complicações pós-operatórias. Shelbourne (1995) avaliou 143 pacientes, divididos em dois grupos, que foram submetidos à reconstrução utilizando o terço médio do ligamento patelar sob as seguintes condições: o primeiro um grupo (47 homens e 17 mulheres; média de idade de 21,9 anos) foi operado com pelo menos 21 dias pós-lesão; o segundo grupo (56 homens e 26 mulheres) foi operado com uma média de 11 dias pós-lesão. Os procedimentos de reabilitação foram iguais para ambos os grupos. Ao final da pesquisa verificou-se que os pacientes do primeiro grupo obtiveram uma maior restauração da força muscular em um prazo menor de tempo além de consequentemente evoluírem mais precocemente nas atividades funcionais.

Shelbourne (1997) revisou 602 pacientes que foram submetidos à cirurgia do LCA entre 1987 e 1992 pelo mesmo cirurgião e ao mesmo protocolo de reabilitação, que objetivava a ADM completa de hiperextensão. Todos os pacientes foram avaliados por um questionário com objetivo de verificar a incidência e a intensidade da dor anterior do joelho. Verificou-se que a incidência de dor anterior do joelho foi menor, isso é, pode ser prevenida, naqueles que obtiveram uma maior hiperextensão do joelho.

Segundo Frobell et al. (2013), verificaram que a reconstrução precoce do LCA junto a fisioterapia pós-operatória, em cinco anos, não foi mais eficaz do que uma estratégia de reabilitação pré-operatória com a reconstrução tardia do ligamento. Em uma investigação com 45 voluntários submetidos a reconstrução do LCA, Lepley e Palmieri-Smith (2016) identificaram que pacientes com melhores resultados pré-cirúrgicos de ativação muscular do quadríceps também apresentaram melhores resultados de ativação do quadríceps no período pós-operatório.

O LCA pode ser reconstruído por uma técnica cirúrgica extra-articular, intra-articular ou combinada. Os procedimentos extra-articulares destinam-se a eliminar os desvios de eixo, porém não conseguem restaurar uma artrocinemática normal através do eixo do LCA normal. As reconstruções intra-articulares podem ser feitas de forma aberta ou por via artroscópica. Existem a vários tipos de tecidos para os reparos intra-articulares, incluindo os autoenxertos, aloenxertos e próteses ligamentares (Andrews, 2000; Vinagre, 2018). O enxerto mais utilizado para a cirurgia é o do ligamento patelar (Rubinstein et al., 1994; Beynnon et al., 2002). Suas principais vantagens são a disponibilidade, viabilidade biológica, qualidade de fixação e elevada força tênsil. De qualquer forma, dor local, artrofibrose, ruptura do tendão, fraturas da patela e a fraqueza do quadríceps são relatadas após esse procedimento (Rubinstein et al., 1994; Andrade, 1999).

Os protocolos de reabilitação acelerada, que se baseiam nos exercícios de cadeia cinética fechada, conforme descrito por Shelbourne (1990), tornaram muito mais rápido o processo de reabilitação. Noyes et al. (1984), sugerem que, na maioria das atividades extenuantes, o LCA só raramente será exposto a mais de $50 \%$ de sua carga máxima. O padrão temporal para a progressão na reabilitação do LCA é bastante variável, embora existam condutas que devem ser enfatizadas para permitir a progressão do paciente, independente do fator tempo. Imediatamente após a cirurgia, deve ser enfatizado o controle da inflamação, a manutenção de uma 
extensão passiva plena, a promoção da mobilidade patelar e o aumento do recrutamento quadricipital (Andrews, 2000). Assim que a incisão estiver devidamente cicatrizada, poderão ser realizadas a mobilização e a dessensibilização da mesma, de modo a tornar o ganho de ADM menos doloroso (Andrews, 2000).

De um modo geral, o indivíduo poderá avançar por um programa de progressão funcional, no qual, com frequência, a corrida é permitida após um período de quatro a seis meses, com retorno às atividades esportivas após seis a doze meses (Andrews, 2000). Um dos fatores que deve ser investigado antes da liberação do paciente para retorno às atividades competitivas é a sua motivação.

\subsection{EXERCÍCIOS RESISTIDOS NA FISIOTERAPIA PÓS-OPERATÓRIA DO LIGAMENTO CRUZADO ANTERIOR}

Poucos trabalhos abordam a questão do exercício resistido e sua efetividade visando a melhora funcional do indivíduo. Sendo assim, torna-se importante abordar a efetividade desses exercícios na fisioterapia pós-operatória da reconstrução do LCA contralateral.

Após a RLCA a força muscular sofre influência morfológica e neural, resultando assim, na perda funcional e significante inibição neural, que por sua vez resultam em atrofia muscular, contribuindo para perda de força e função (Buckthorpeet al,.2019).

Shaw et al. (2005) em um estudo clínico randomizado prescreveu exercícios de elevação do membro estendido e contrações isométricas do quadríceps, observando sua efetividade nas duas primeiras semanas após a RLCA. Embora não tenha apresentado diferença significativas no desempenho muscular e capacidade sensório-motora entre os grupos, concluiu que esses exercícios não geram complicações do ponto de vista clínico-funcional e aceleravam o processo de ganho de amplitude de movimento e estabilidade articular.

Gerber et al. (2009) concluiu após estudo clínico randomizado, no qual utilizou-se de exercícios excêntricos e reabilitação convencional durante 12 semanas desde o início da reabilitação, que o grupo intervenção apresentou maior ganho de volume e função muscular de quadríceps e glúteo máximo em comparação ao grupo controle.

Por fim, Escamilla et al. (2012) apresenta e compara as evidências acerca dos exercícios com e sem descarga de peso na reabilitação após reconstrução do LCA, abordando o estresse gerado sobre o enxerto nos diferentes tipos de exercício. A autora conclui que os exercícios sem descarga de peso (cadeia cinética aberta) apresentaram maior sobrecarga sobre o enxerto do LCA, principalmente entre os $10^{\circ}$ e $50^{\circ}$ durante a flexão de joelho, alcançando maior sobrecarga entre $10^{\circ}$ e $30^{\circ}$. Já nos exercícios com descarga de peso (cadeia cinética fechada) a sobrecarga sobre o enxerto do LCA ocorre entre $50^{\circ}$ a $100^{\circ}$ de flexão do joelho, aumentando em agachamentos em que o joelho ultrapasse a linha dos dedos do pé e o calcanhar esteja fora do chão.

Kristensen e Franklyn-Miller (2012) indicam que exercícios de baixa a moderada intensidade são benéficos durante a reabilitação inicial da reconstrução 
do LCA, no entanto não se sabe ao certo qual intensidade de exercícios seriam mais benéficos a reabilitação a longo prazo, visto que a fraqueza muscular nos pacientes é evidente.

\subsection{AVALIAÇÃO ISOCINÉTICA E FUNCIONAL DO JOELHO}

A avaliação isocinética utiliza uma velocidade fixa pré definida, que varia de $1 \%$ a aproximadamente $1000 \%$, permitindo a acomodação da resistência por meio da amplitude de movimento. A resistência oferecida pelo aparelho varia de forma a ser sempre igual a força exercida pelo indivíduo, possibilitando assim, carregar dinamicamente um músculo até sua capacidade máxima em todos os ângulos de movimentação do joelho (Batzopoulos, 2017; Davies et al., 2018)

Vários protocolos específicos para testar determinados parâmetros em diferentes populações são propostos na literatura (Bernard et al., 2016; Machado et al., 2018). No entanto, é certo que fatores como o aquecimento da musculatura, treinamento prévio, posição e estabilização do sujeito, amplitude de movimento, tempo de descanso entre as séries, incentivo verbal e especificações do aparelho podem, influenciar os resultados obtidos e levar a erros na sua interpretação (Aquino et al., 2008; Undheim et al., 2015).

O exame isocinético no joelho, para avaliação ou para reabilitação, pode utilizar velocidades angulares que variam. Para o melhor estudo do pico de torque e do trabalho, utiliza-se velocidade angular do tipo lenta $(60 \%)$, pois quanto menor a velocidade angular maior é o torque ou o trabalho. Já para a avaliação da potência, costuma-se usar velocidades de $180 \%$ s a $300 \%$ s (Terreri et al., 2001).

Os parâmetros de análise da avaliação isocinética em pacientes pós-cirúrgicos do LCA incluem: (1) O pico de torque ou momento de força, que é o ponto de maior torque na amplitude de movimento; (2) $O$ trabalho total, representando a energia total realizada no esforço muscular durante o movimento; (3) A relação de equilíbrio agonista/antagonista, sendo a divisão entre do valor do músculo agonista e do antagonista, seja relacionado ao pico de torque, trabalho ou potência (Carvalho e Puga, 2010).

É na avaliação funcional, como em todo aparelho locomotor, que o dinamômetro isocinético apresenta seu ponto estratégico de aplicação, constituindo-se num importante método auxiliar para tal investigação (Terreri et al., 2001). Diversos estudos demonstram correlações positivas entre os resultados da avaliação isocinética e o desempenho funcional de pessoas com e sem lesão nos joelhos. Patel et al. (2003) realizou o teste isocinético com 44 indivíduos saudáveis e 44 indivíduos com lesão do LCA. O grupo com lesão apresentou força de quadríceps significativamente menor que o grupo controle, o que foi relacionado a diminuições importantes do momento de força do quadríceps durante atividades de corrida, salto ou subir escadas.

Karanikas et al. (2009) Correlacionaram os achados entre a força muscular isocinética e a cinemática da marcha e corrida após a reconstrução do LCA. Os resultados mostraram que pacientes com déficits significativos de força também 
demonstraram estratégias anormais de cinemática da locomoção. Laudner et al. (2015) investigaram os resultados de testes de salto e avaliação de força em 33 pacientes após 6 meses de reconstrução do LCA. O desfecho do estudo indicou que o desempenho dos voluntários durante os testes de salto unilaterais, bilaterais e saltos consecutivos apresentaram correlações positivas com as medidas de força isocinética dos joelhos. As deficiências de controle neuromuscular e risco de futuras lesões têm sido avaliadas por meio de testes de salto, aterrissagem e equilíbrio unipodal, além de avaliações de padrões de movimento (Smith et al. 2015).

O Y Balance Test (YBT) é uma variação instrumentada do Star Excursion Balance TEST (SEBT), que tem por objetivo investigar a performance durante o equilíbrio unipodal ao alcançar três direções: anterior, póstero-lateral e póstero-medial, visando determinar assimetrias de extremidades inferiores e déficits de equilíbrio. Se trata de um teste rápido, prático e que gera resultados objetivos em relação a assimetrias e instabilidades entre membros.

Conforme Gonell et al. (2015), assimetrias e índices fora do esperado para determinado perfil indicam que uma disfunção no sistema neuromuscular pode estar presente, o que pode levar a maior probabilidade de lesões do LCA sem contato.

O Single Leg Hop Test (SLHT) é um dos métodos que visa avaliar e comparar assimetrias e estabilidade entre membros, predizendo uma possível alta e retorno ao esporte. Durante o salto unipodal horizontal, o paciente é orientado a se equilibrar em uma perna e saltar o mais longe possível e se possível, realizar o teste com as duas pernas, visando uma comparação entre membros e análise de assimetrias. Como base para avaliação de assimetrias entre membros do paciente, visando analisar força, função e mobilidade, é utilizado o Limb Symmetry Index (LSI) que consiste em um guia para mensuração objetiva de discrepâncias. O resultado do LSI é dado em porcentagem e considerado satisfatório acima de $90 \%$. De acordo com Wellsandt et al. (2017), esse método de comparação tem superestimado a função do joelho após a RLCA e tem estado relacionado a uma possível re-ruptura ligamentar.

Benjaminse et al. (2018) também indicam que os critérios de alta com base nos dados de LSI obtidos através doo SLHT devem ser utilizados com cautela quando utilizados como critério primário para retorno ao esporte após uma reconstrução do ligamento cruzado anterior. Ainda segundo os autores, mesmo que alcancem a simetria entre membros, pacientes que não alcancem os índices ré lesão apresentam um maior risco de uma segunda lesão do LCA, visto que os dados SLI subestimam a performance e déficits funcionais.

\subsection{QUESTIONÁRIOS PARA AVALIAÇÃO DA FUNÇÃO DO JOELHO}

Durante escolha de melhor tratamento, faz-se necessária a aplicação de questionários que objetivam avaliar de forma subjetiva dor, funcionalidade e instabilidade do joelho tanto nas atividades de vida diária quanto na prática esportiva.

Visando avaliar os sintomas de instabilidade, o questionário de Lysholm apresenta um questionário simples sobre função e sintomas no joelho na vida diária(Lysholm, 1982), uma escala de 0 a 100 pontos indica o resultado, sendo de 91 a 100 pontos um excelente resultado, 84 a 90 pontos um bom resultado, entre 65 e 83 
pontos um resultado regular e abaixo de 64 pontos, um resultado ruim.(Kose et al., 2015).

Em busca de avaliar os sintomas e limitações durante as atividades de vida diária, é utilizada uma escala. A escala de atividades de vida diária, validada em 2008 para o português (Gonçalves et al., 2008), é dividida em duas partes e conta com 14 itens no total, sendo 6 para avaliação de sintomas (dor, rigidez, inchaço, instabilidade, fraqueza e claudicação) e 8 para avaliação das limitações funcionais (caminhar, subir e descer escadas, ficar em pé, agachar, ajoelhar, dobrar o joelho em $90^{\circ}$, levantar da cadeira) (Szczepanik, 2018).

No momento de avaliar a dor, há diferentes escalas, sendo a mais prática e utilizada, a escala unidimensional, a qual avalia somente a intensidade da dor. Já as escalas multidimensionais, visam avaliar não somente a intensidade, mas também a localização e duração da dor em toda sua complexidade (Martinez et al., 2011). A escala analógica visual de dor (EVA) apresenta uma linha numerada de 0 a 10 e em uma extremidade está descrito "nenhuma dor" e na outra extremidade "pior dor imaginável". É pedido ao paciente que marca sobre a linha a intensidade de sua dor. Apesar de serem subjetivas e dependerem de fatores pessoais, as escalas são validadas e confiáveis para mensuração da dor. (Da Silva e Deliberato., 2009).

\section{MÉTODOS}

\subsection{TIPO DE ESTUDO E DELINIAMENTO}

Foi realizado um ensaio clínico randomizado, paralelo, prospectivo, cego, com 88 pacientes submetidos à cirurgia de reconstrução do ligamento cruzado anterior com enxerto do ligamento da patela contralateral.

\subsection{AMOSTRA}

Para obtenção dos sujeitos da pesquisa, foram recrutados pacientes atendidos no Hospital Ortopédico e Medicina Especializada - HOME / Centro Médico de Excelência da FIFA, localizado na Asa Sul, Brasília/DF, durante os anos de 2017 a 2019.

\subsubsection{CRITÉRIOS DE INCLUSÃO}

Foram incluídos no estudo pacientes de ambos os gêneros, com ocupações distintas, que praticavam atividade física regularmente, sofreram a lesão traumática aguda do LCA e foram submetidas a um tratamento comum, baseado no modelo de simetria joelho, descrito Biggs et al. (2009), Shelbourne (2000, 2005, 2006), Shelbourne et al. (2007) e Shelbourne et al. (2015). O programa envolve fisioterapia pré-operatória, a cirurgia de reconstrução com enxerto do ligamento da patela contralateral pela mesma equipe médica/procedimento e a fisioterapia pós-operatória até o terceiro mês, desde que fossem capazes de serem submetidos aos critérios de avaliação e iniciar os exercícios resistidos sem restrições. 
Para que a faixa etária de maior prevalência de lesões do LCA no Brasil (Lopes et al., 2016) fosse respeitada, somada à exclusão de menores de idade, todos(as) deveriam ter a idade compreendida entre 18 e 55 anos.

\subsubsection{CRITÉRIOS DE NÃO INCLUSÃO}

Pacientes que preenchiam os critérios de inclusão, porém eram atletas profissionais, possuíam histórico de lesões e(ou) cirurgia nos membros inferiores, cardiopatas, portadores de outras afecções de correlação sistêmica, gestantes/lactantes foram dispensados(as).

\subsubsection{CRITÉRIOS DE EXCLUSÃO}

Foram excluídos do estudo aqueles(as) que não concluíssem todas as etapas da pesquisa, apresentassem dor que impedisse a realização dos procedimentos de avaliação e(ou) não seguissem as orientações necessárias.

\subsubsection{CÁLCULO AMOSTRAL}

Para que os resultados da pesquisa fossem representativos, foi desenhado um plano amostral com intervalo de confiança de 95\% e significância de 5\%, considerando a maior variância (50\%). Foi considerado o tamanho da população alvo como 800 pacientes, que é número de cirurgias realizadas por esse método pela equipe médica responsável até dezembro de 2016, e o desempenho muscular na avaliação isocinética como desfecho principal. Esperava-se a diferença máxima $\leq 10 \%$ entre os membros doador e receptor com a intervenção proposta.

O cálculo do tamanho das amostras foi efetuado com base na estimação de proporções. Para atingir o intervalo de confiança e margem de erro tolerável escolhidos, foram calculadas amostras com base nas seguintes equações descritas em Cochran (1977):

$$
\begin{aligned}
& n_{0}=\left(\frac{Z_{\partial / 2}}{d}\right)^{2} p(1-p) \\
& n=\frac{n_{0}}{1+n_{0} / N}
\end{aligned}
$$

- P é a proporção populacional de cada variável em estudo. Porém, sendo esta proporção desconhecida, foi considerado o valor mais desfavorável (que conduz à maior variância) de, neste caso, 0,5;

- é o valor da distribuição normal referente ao nível de significância escolhido (cujo valor é 1,96);

- d é a margem de erro tolerável de, neste caso, 10 pontos percentuais (acima ou abaixo das proporções obtidas nas sondagens);

- N é o tamanho da população e n o tamanho da amostra.

Foi utilizada uma correção para populações finitas descrita na equação acima. 
Diante do cálculo, chegou-se ao número amostral de 88 pacientes, divididos igualmente em Grupos Intervenção (GI) $(n=44)$ e Controle (GC) $(n=44)$.

\subsection{PROCEDIMENTOS DA PESQUISA}

\subsubsection{ASPECTOS ÉTICOS E REGISTRO DA METODOLOGIA}

Anteriormente à realização de qualquer procedimento metodológico, esta pesquisa foi aprovada pelo Comitê de Ética da Universidade Federal de São Paulo / Escola Paulista de Medicina (UNIFESP/EPM), sob o CAE 02262512.4.0000.5505. Todos(as) os(as) participantes eram voluntários(as) e assinaram um Termo de Consentimento Livre e Esclarecido (TCLE), dando ciência de que conheciam os procedimentos a serem realizados e concordavam com os objetivos da pesquisa.

A metodologia utilizada foi registrada na plataforma de Registro Brasileiro de Ensaios Clínicos com o número do UTN U1111-1207-3123.

\subsection{PROGRAMA DE FISIOTERAPIA PRÉ-OPERATÓRIA}

O programa de tratamento fisioterapêutico na fase pré-operatória teve por objetivo controlar o processo inflamatório, restaurar a amplitude de movimento, melhorar o desempenho muscular (DM), a capacidade sensório-motora (CSM), obter a deambulação normal e incentivar a adesão efetiva ao tratamento e intervenção, de modo que os(as) pacientes se dedicassem plenamente às diferentes fases de recuperação, assim atingissem os resultados esperados (Shelbourne, 2000, 2005, 2006; Shelbourne et al., 2007; Biggs et al., 2009; Shelbourne et al., 2015).

Inicialmente foi dada atenção ao processo inflamatório geral, por meio de aplicações de gelo, compressão e elevação do membro. Exercícios de mobilidade para flexão, extensão e hiperextensão foram iniciados precocemente, para possibilitar o restabelecimento da ADM normal e impedir complicações, como fibrose na fossa intercondilar femoral e reduções excessivas do tônus e trofismo do membro lesionado (Figuras 1 e 2) (Shelbourne, 2000, 2005, 2006; Shelbourne et al., 2007; Biggs et al., 2009; Shelbourne et al., 2015). 

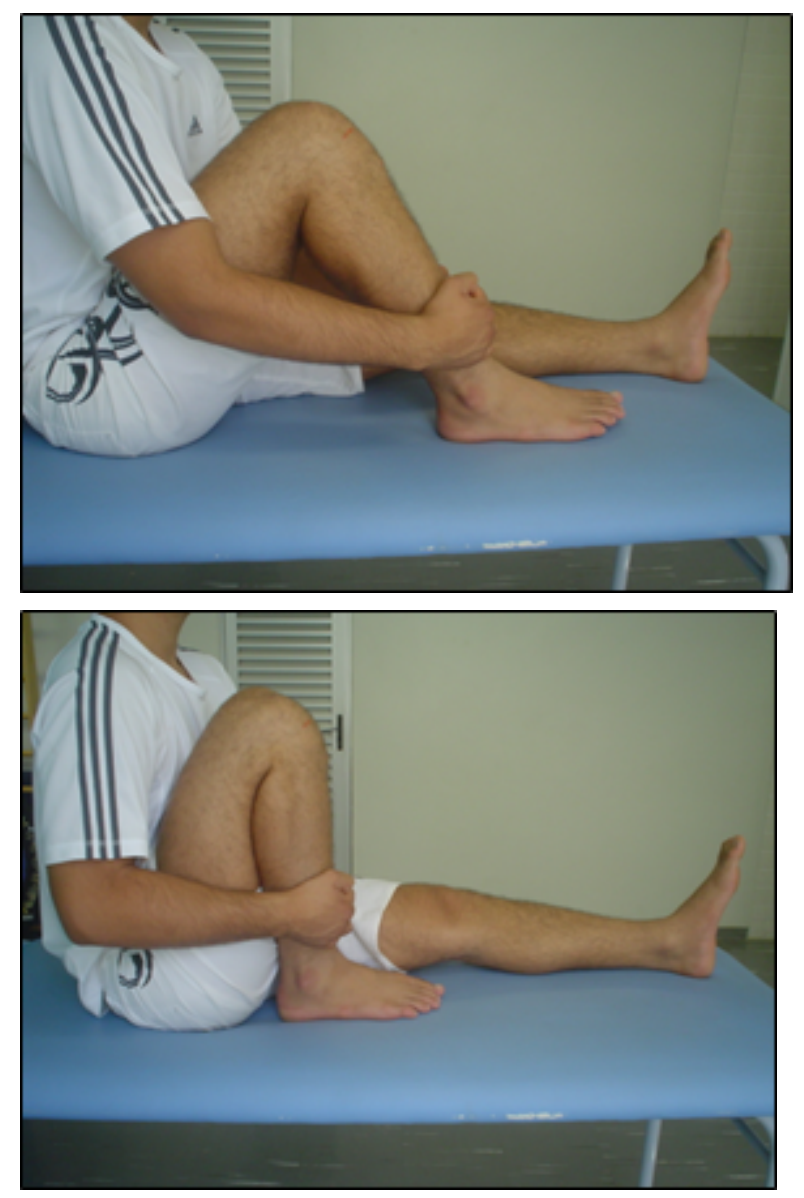

Fonte: Arquivo pessoal do autor (2006).

Figuras 1 e 2. Exercícios de mobilidade realizados na fase inicial de fisioterapia pré-operatória

Os exercícios resistidos foram realizados inicialmente de forma isométrica e por meio de elevação do membro estendido, também conhecidas como straight leg raise ou SLR. Após a ADM ter sido restaurada, foram incluídos exercícios concêntricos e excêntricos em CCA e CCF (Shelbourne, 2000, 2005, 2006; Shelbourne et al., 2007; Biggs et al., 2009; Shelbourne et al., 2015). A capacidade sensório-motora também foi incentivada desde o primeiro momento, por meio da realização de exercícios com o objetivo de diminuir o período de latência da condução nervosa, aumentando então a velocidade da resposta neuromuscular e consequentemente melhorando a funcionalidade dos(as) pacientes, diminuindo o risco de lesões adicionais e agravamento do quadro inicial (Shelbourne, 2000, 2005, 2006; Shelbourne et al., 2007; Biggs et al., 2009; Shelbourne et al., 2015). 

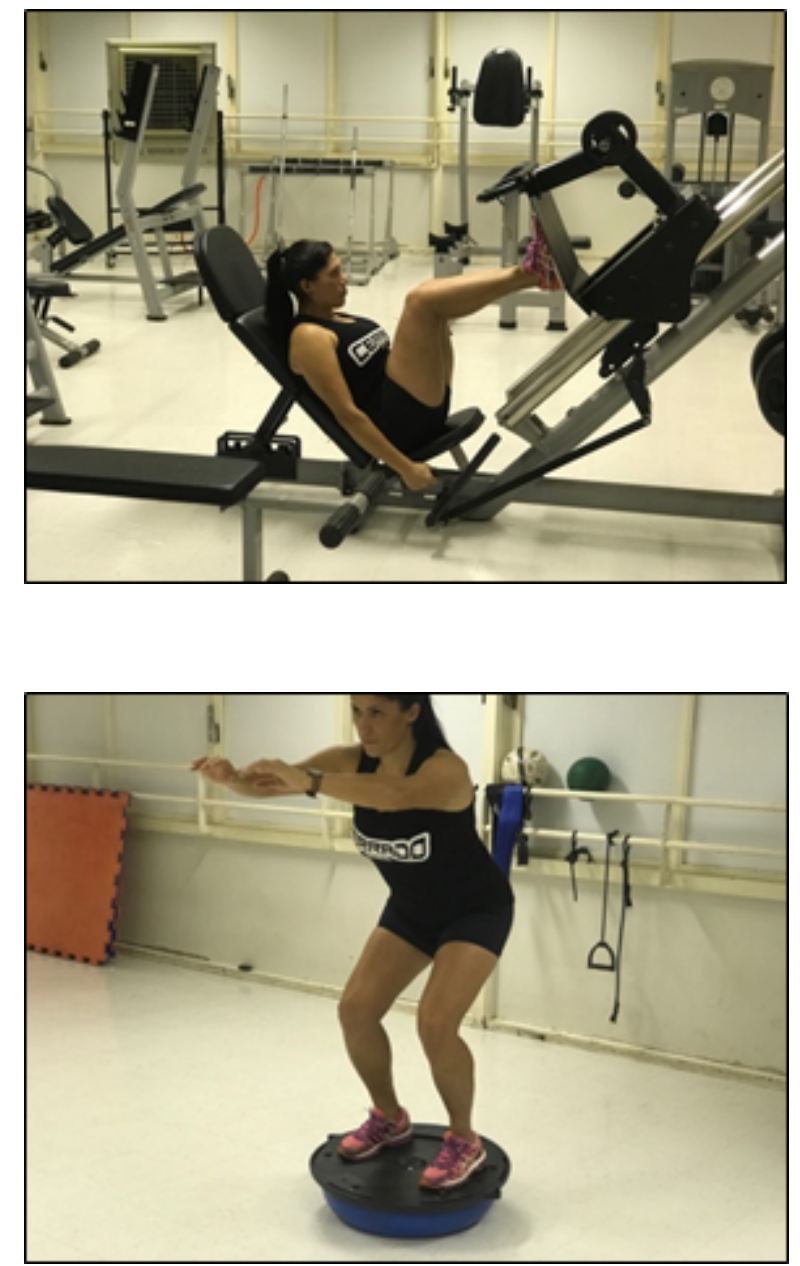

Fonte: Arquivo pessoal do autor (2019).

Figuras 3 e 4 . Exercícios resistidos e sensório-motores na fisioterapia pré-operatória

Devido à instabilidade gerada pela ausência do LCA, nesta fase os exercícios foram realizados de forma estática, sem corridas ou saltos (Shelbourne, 2000, 2005, 2006; Shelbourne et al., 2007; Biggs et al., 2009; Shelbourne et al., 2015).

A fase pré-operatória foi concluída à véspera da cirurgia, quando os(as) pacientes encontravam-se livres de sinais inflamatórios agudos, com a ADM e trofismo restaurados, bom controle neuromuscular, deambulando normalmente, plenamente motivados(as) e com o procedimento cirúrgico programado(Shelbourne, 2000, 2005, 2006; Shelbourne et al., 2007; Biggs et al., 2009; Shelbourne et al., 2015). O tempo médio de tratamento pré-operatório foram 4 semanas. 

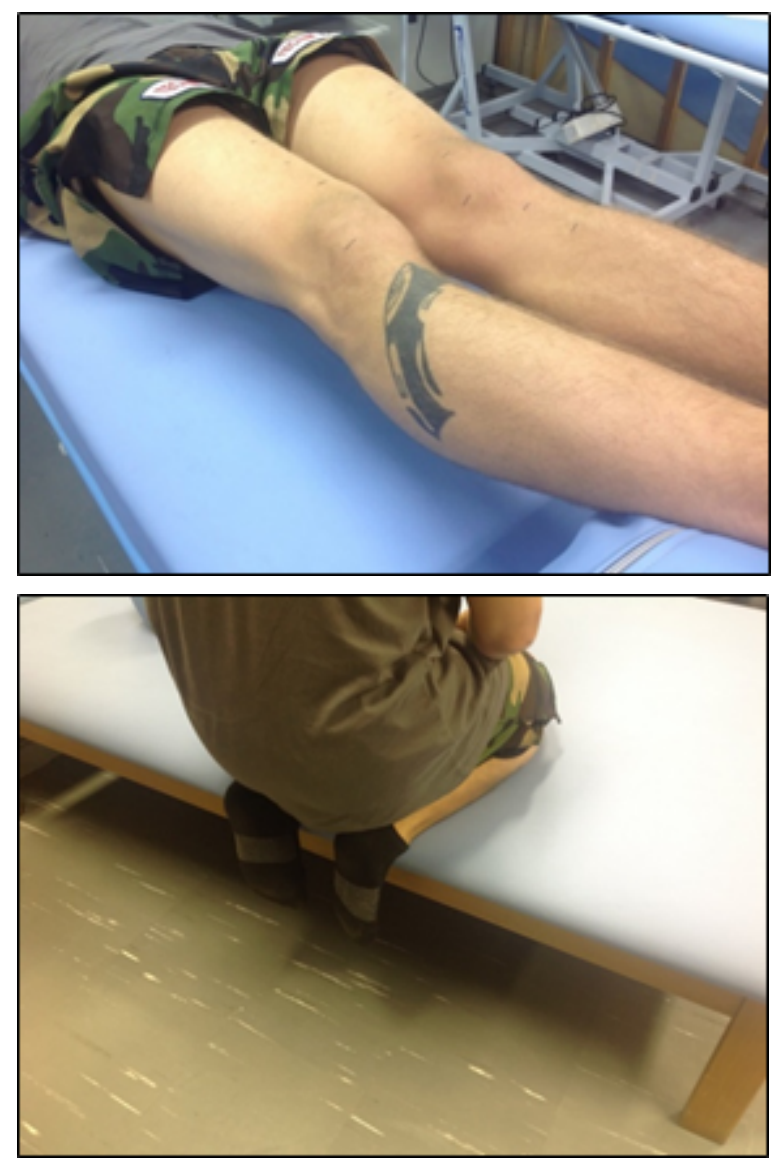

Fonte: Arquivo pessoal do autor (2018).

Figuras 5 e 6 . Aspecto geral de paciente ao final do período pré-operatório

\subsection{PROCEDIMENTO CIRÚRGICO}

Todas as cirurgias foram feitas pela mesma equipe médica, que compõe o Departamento de Traumatologia Esportiva do Hospital HOME. O procedimento realizado foi baseado no descrito por (Shelbourne et al., 2000, 2005; Prodomos et al., 2005), sendo todas as abordagens feitas por meio da técnica anatômica, via portal medial, de forma simultânea nos dois joelhos, receptor e doador - enquanto neste é feita a retirada do enxerto, naquele é feita a artroscopia.

Em relação ao procedimento do doador, inicialmente faz-se uma incisão no paratendão medial com divulsão por planos. A partir da abertura do peritendão, são feitas marcações no ligamento da patela com $10 \mathrm{~mm}$ de largura, na patela e na tíbia de $20 \mathrm{~mm}$ de comprimento e retirados os plugs ósseos com $10 \mathrm{~mm}$ de profundidade com uma serra oscilatória. Após a retirada do enxerto, é feito o fechamento da área doadora com fio de vicril 1.0, incluindo bainha e tendão. É então colocado o enxerto ósseo na falha da patela (proveniente do túnel tibial do joelho receptor) (Figuras 7 e 8) (Carneiro-Filho et al., 1999; Shelbourne et al., 2000, 2005; Prodomos et al., 2005). 

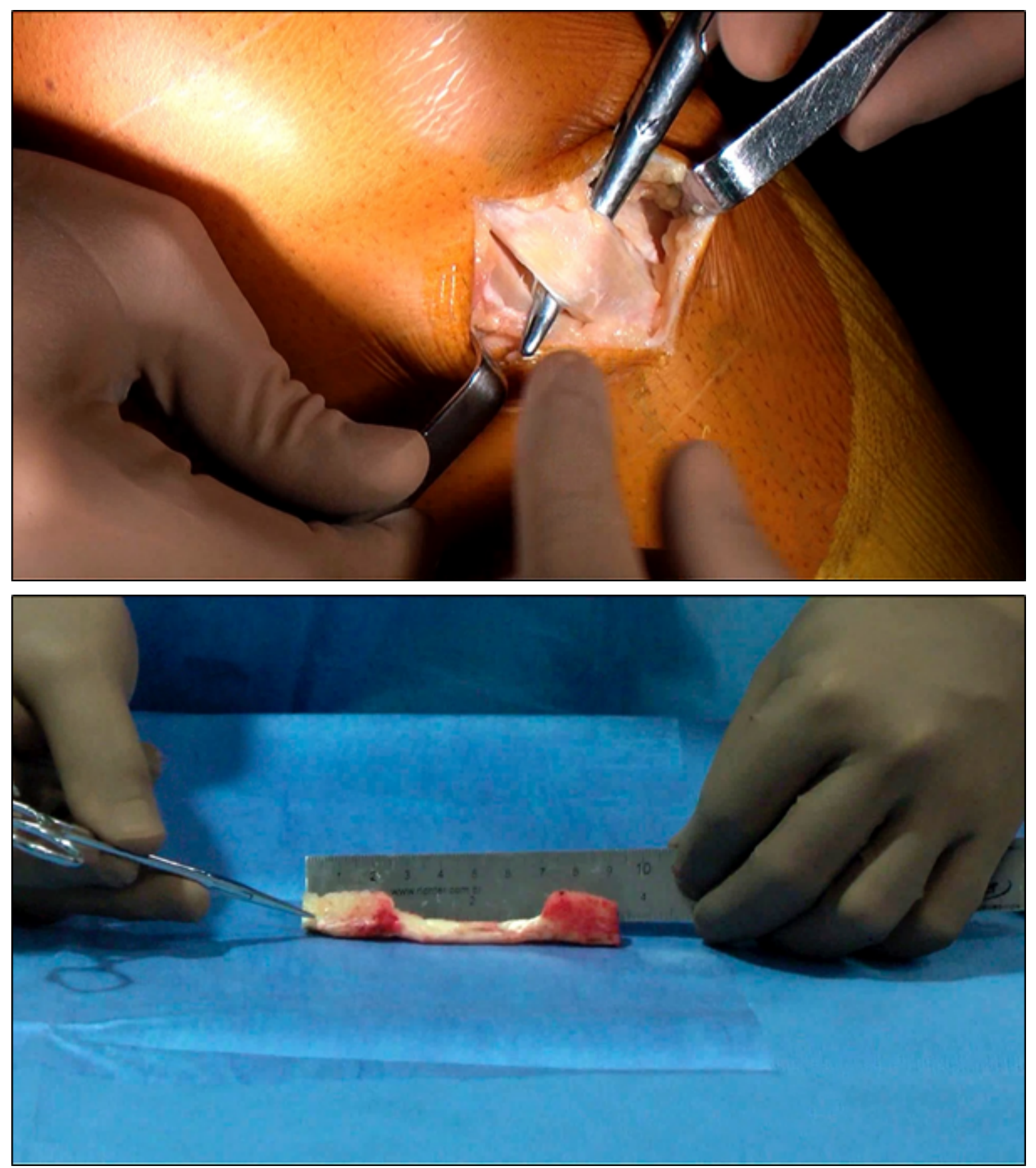

Fonte: Arquivo pessoal do autor (2019).

Figuras 7 e 8 . Retirada e preparação do enxerto no joelho doador

No joelho receptor são feitos os portais artroscópicos e, em seguida, uma sinovectomia com limpeza do footprint da tíbia e do fêmur, seguindo o padrão da cirurgia artroscópica. O joelho é então posicionado sobre a mesa cirúrgica em flexão de 120 graus. Pelo portal medial é feito o túnel do fêmur, localizado aproximadamente entre as bandas ânteromedial (AM) e pósterolateral ( $P L)$, um pouco mais medial, tentando reproduzir a banda AM. O túnel da tíbia é feito com o joelho fora da mesa e flexionado a 90 graus, utilizando um guia tibial. O footprint da tíbia se localiza na região medial do platô tibial, tendo como referência a borda posterior do corno anterior do menisco lateral. Após a medição dos túneis, o enxerto é passado com o joelho flexionado em 45-90 graus, fixado no fêmur com endobutton CL BTB (Smith \& Nephew) 
e na tíbia com parafuso bioabsorvível (Smith \& Nephew) com o joelho em 0-20 graus de flexão. Por último, é colocado o dreno intrarticular de sucção, feito a sutura de portais com fio nylon 4.0 e a sutura da incisão do joelho doador (Zekcer et al., 2011; Shelbourne et al., 2000, 2005; Prodomos et al., 2005).

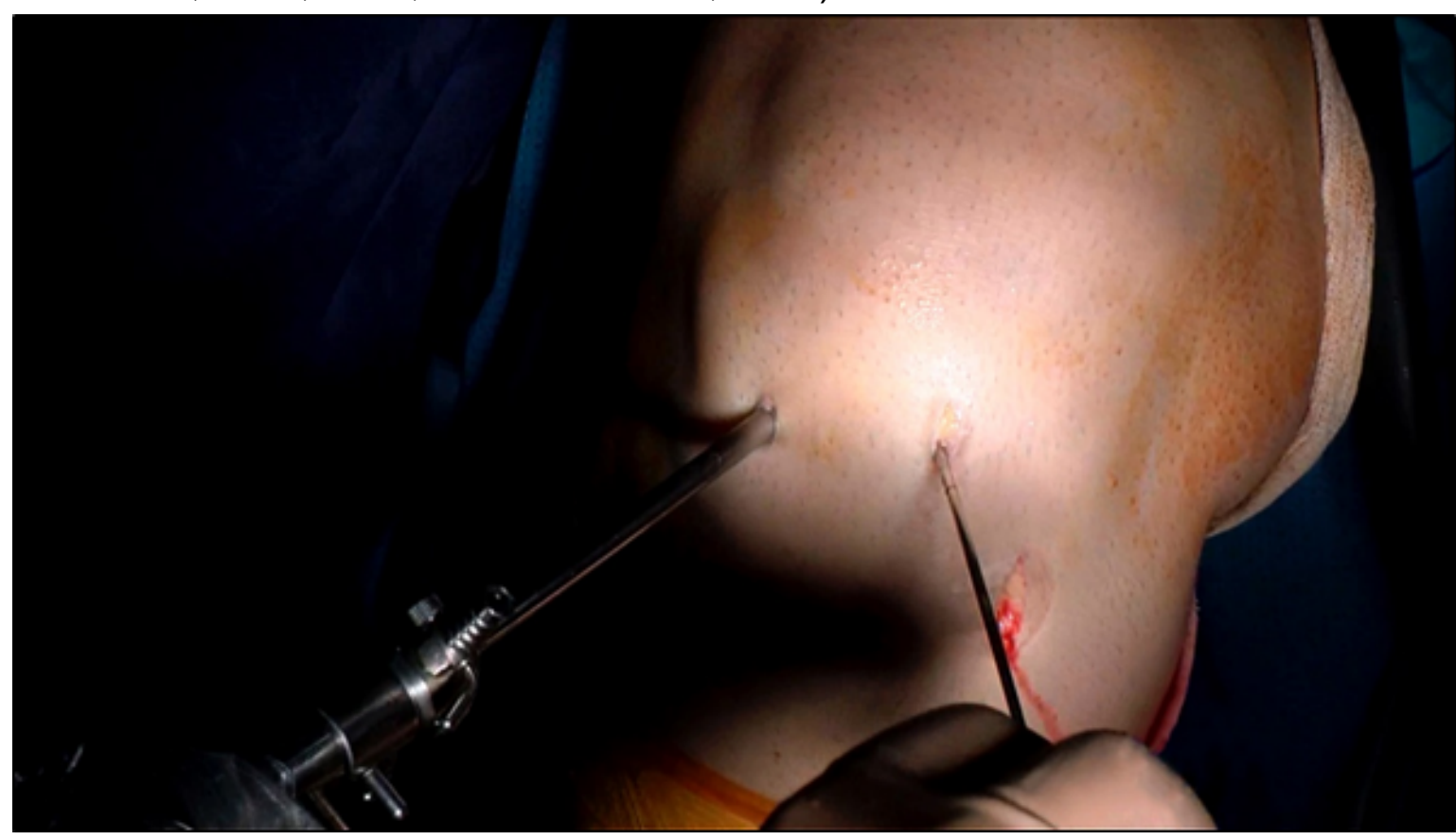

Fonte: Arquivo pessoal do autor (2019)

Figura 9. Aspecto geral do joelho receptor durante o procedimento de reconstrução do LCA

\subsection{PROGRAMA DE FISIOTERAPIA PÓS-OPERATÓRIA}

A etapa de tratamento pós-operatória foi iniciada ainda com o paciente estando nas instalações do hospital, durante o período de internação. Após a alta, foi dividida em semanas até o final do primeiro mês, quando então passou a ser considerada em meses. Os objetivos, independente do paciente, foram eliminar a dor e hemartrose, restaurar a ADM e iniciar os exercícios de fortalecimento muscular junto à progressão sensório-motora. Os membros foram divididos quanto aos objetivos, de modo que no doador almejava-se estimular a regeneração e desenvolvimento da área doadora, para que se pudesse restabelecer o desempenho muscular, e no receptor, o controle da hemartrose, restabelecimento da ADM e estímulo à maturação do enxerto (Shelbourne, 2000, 2005, 2006; Shelbourne et al., 2007; Biggs et al., 2009; Shelbourne et al., 2015).

Imediatamente após o procedimento cirúrgico, no ambiente de internação, foram iniciadas as condutas específicas para cada joelho (Shelbourne, 2000, 2005, 2006; Shelbourne et al., 2007; Biggs et al., 2009; Shelbourne et al., 2015).

- Receptor: exercícios de mobilidade, isométricos para prevenir a perda de trofismo e crioterapia;

- Doador: exercícios de mobilidade, resistidos concêntricos e excêntricos para estímulo à área doadora e crioterapia. 
Ambos os membros foram liberados para descarga de peso e marcha com auxílio de muletas no dia seguinte ao procedimento (Shelbourne, 2000, 2005, 2006; Shelbourne et al., 2007; Biggs et al., 2009; Shelbourne et al., 2015).

Após a saída do hospital (24 horas de internação) e até o final da primeira semana, quando ocorreu o primeiro retorno à equipe médica, os pacientes mantiveram os exercícios e condutas anteriormente realizadas em domicílio. Após a primeira semana, foram iniciados agachamentos unipodais com o joelho doador (Shelbourne, 2000, 2005, 2006; Shelbourne et al., 2007; Biggs et al., 2009; Shelbourne et al., 2015).
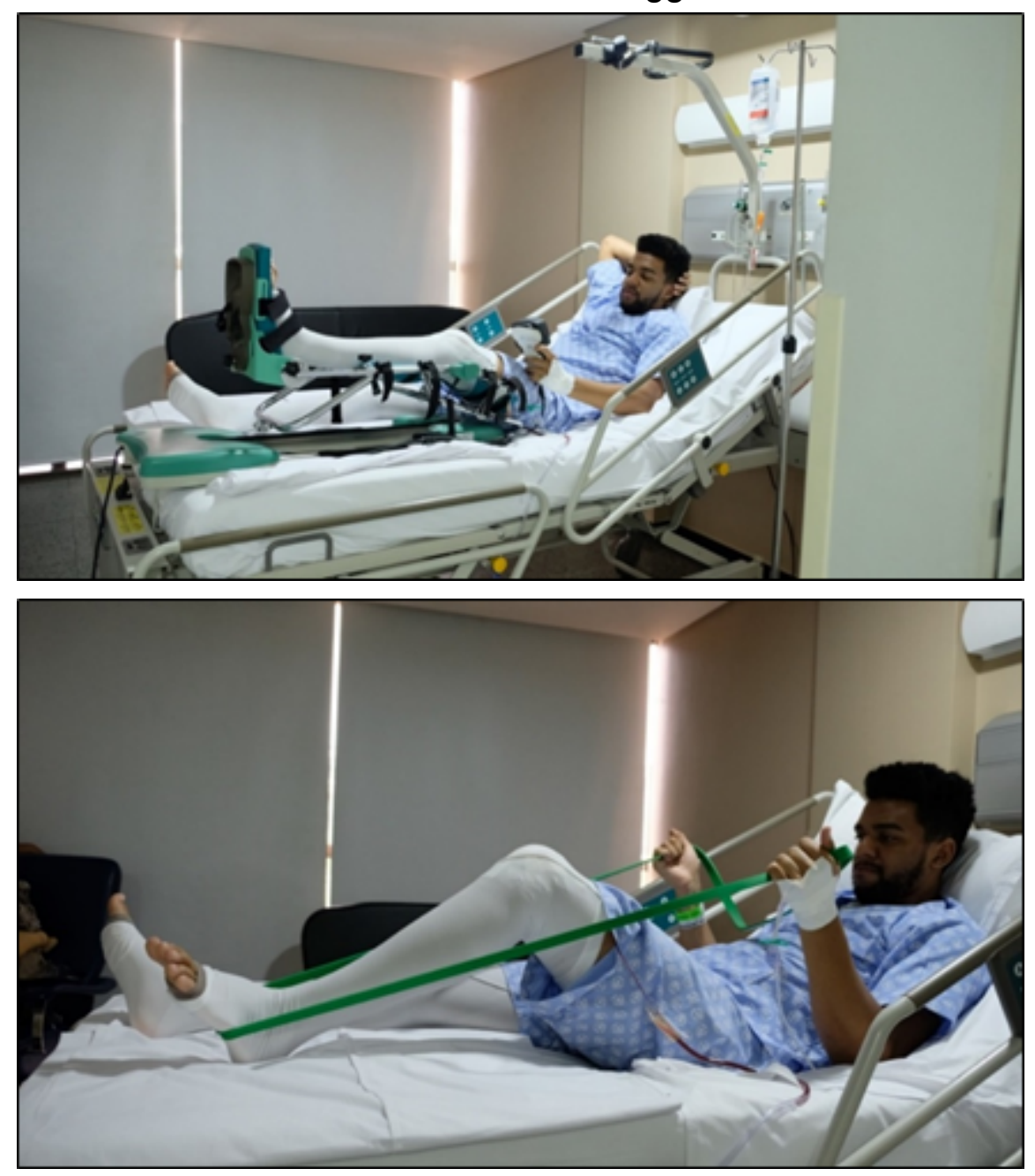

Fonte: Arquivo pessoal do autor (2019).

Figuras 10 e 11. Início da fisioterapia pós-operatória 


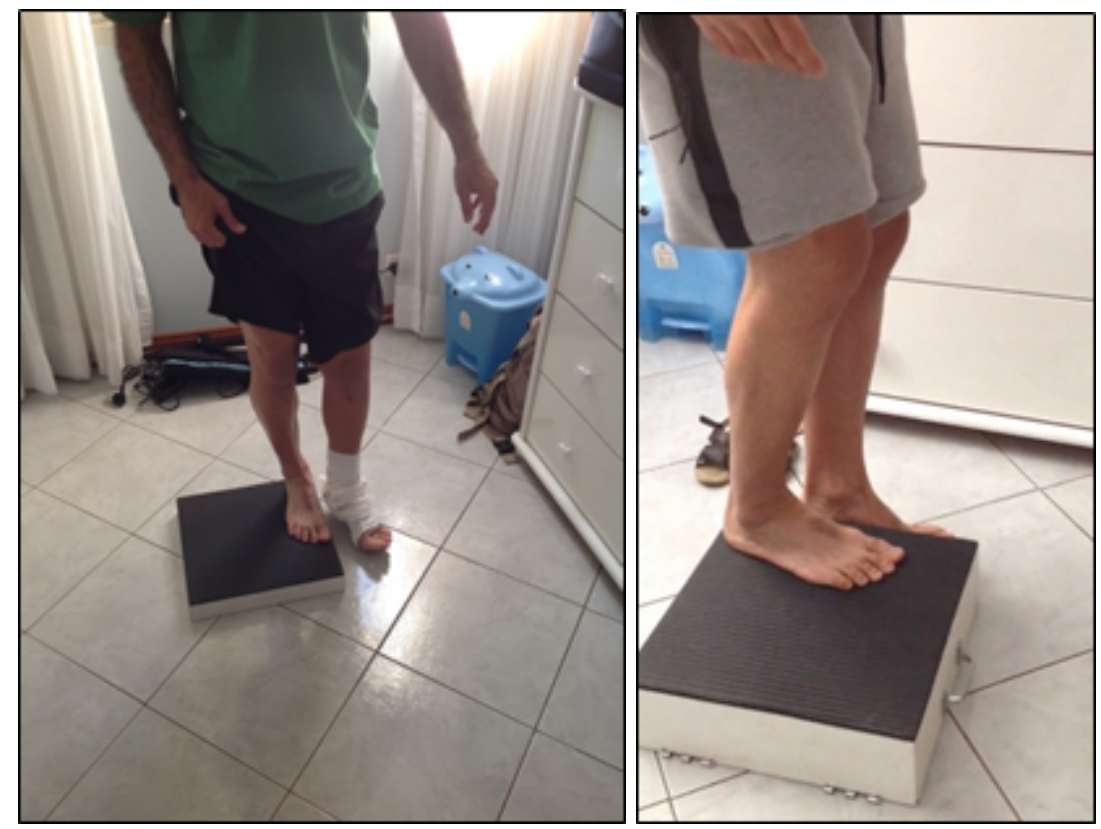

Fonte: Arquivo pessoal do autor (2019).

Figuras 12 e 13. Exercícios unipodais domiciliares com step box

A segunda visita ocorreu com 15 dias de $\mathrm{PO}$, para verificação radiológica da posição do enxerto e retirada da sutura, liberando então os(as) pacientes para a fisioterapia ambulatorial.

Os pacientes foram submetidos a três sessões de fisioterapia semanais e a evolução se baseou no momento em que atingissem a flexão completa no joelho receptor, momento em que foram iniciados os exercícios resistidos visando o controle e a coordenação do movimento, associado ao aumento progressivo de carga e retorno simultâneo da simetria bilateral (Shelbourne, 2000, 2005, 2006; Shelbourne et al., 2007; Biggs et al., 2009; Shelbourne et al., 2015). Depois de atingidos esses critérios, os pacientes deveriam estar independentes funcionalmente para todas as suas atividades de vida diária e a fisioterapia teve o objetivo de progredir nas atividades até o final do terceiro mês $\mathrm{PO}$, quando, de acordo com a randomização da amostra, foram alocados em um dos grupos - Controle (GC) ou Intervenção (GI). 

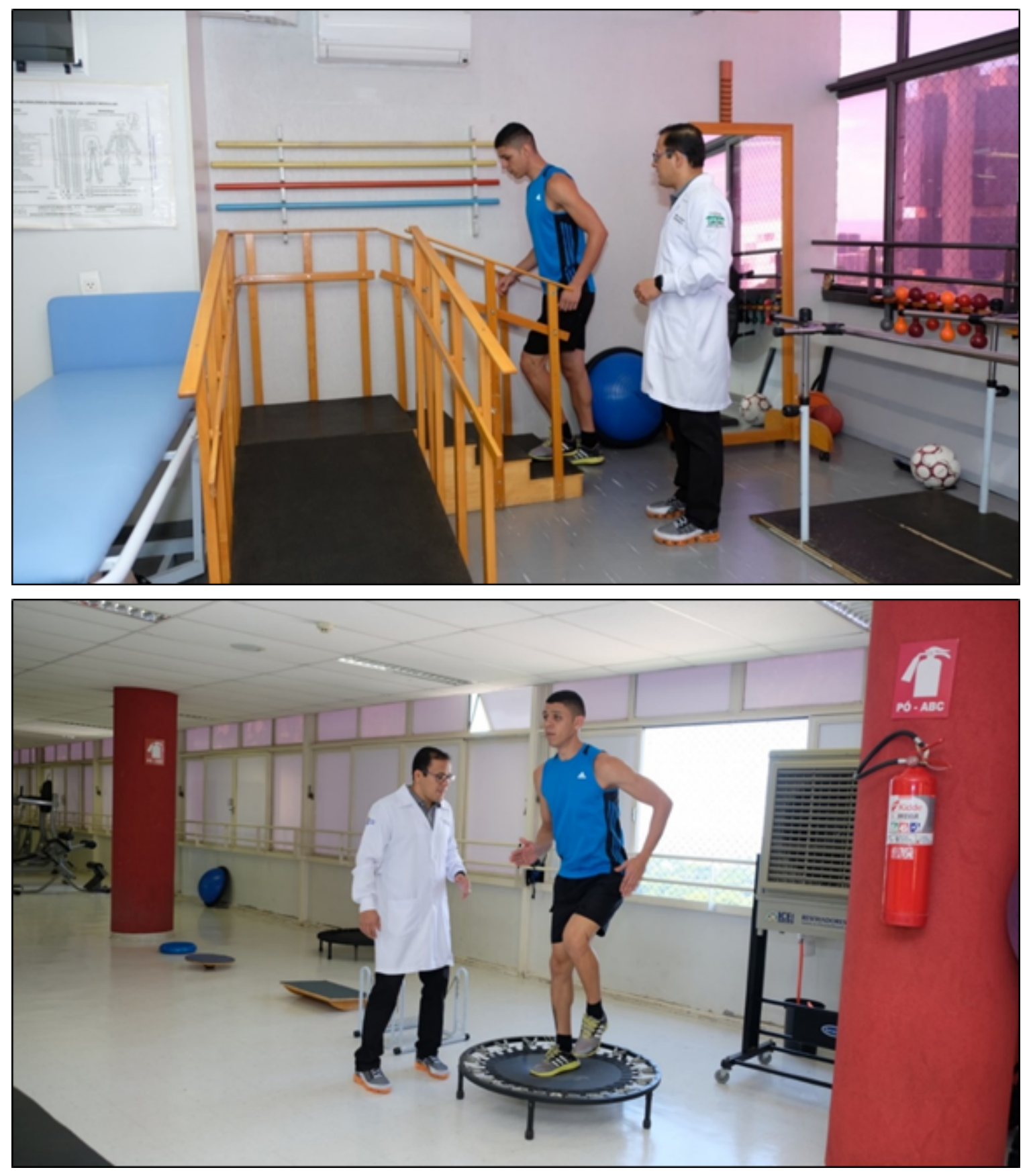


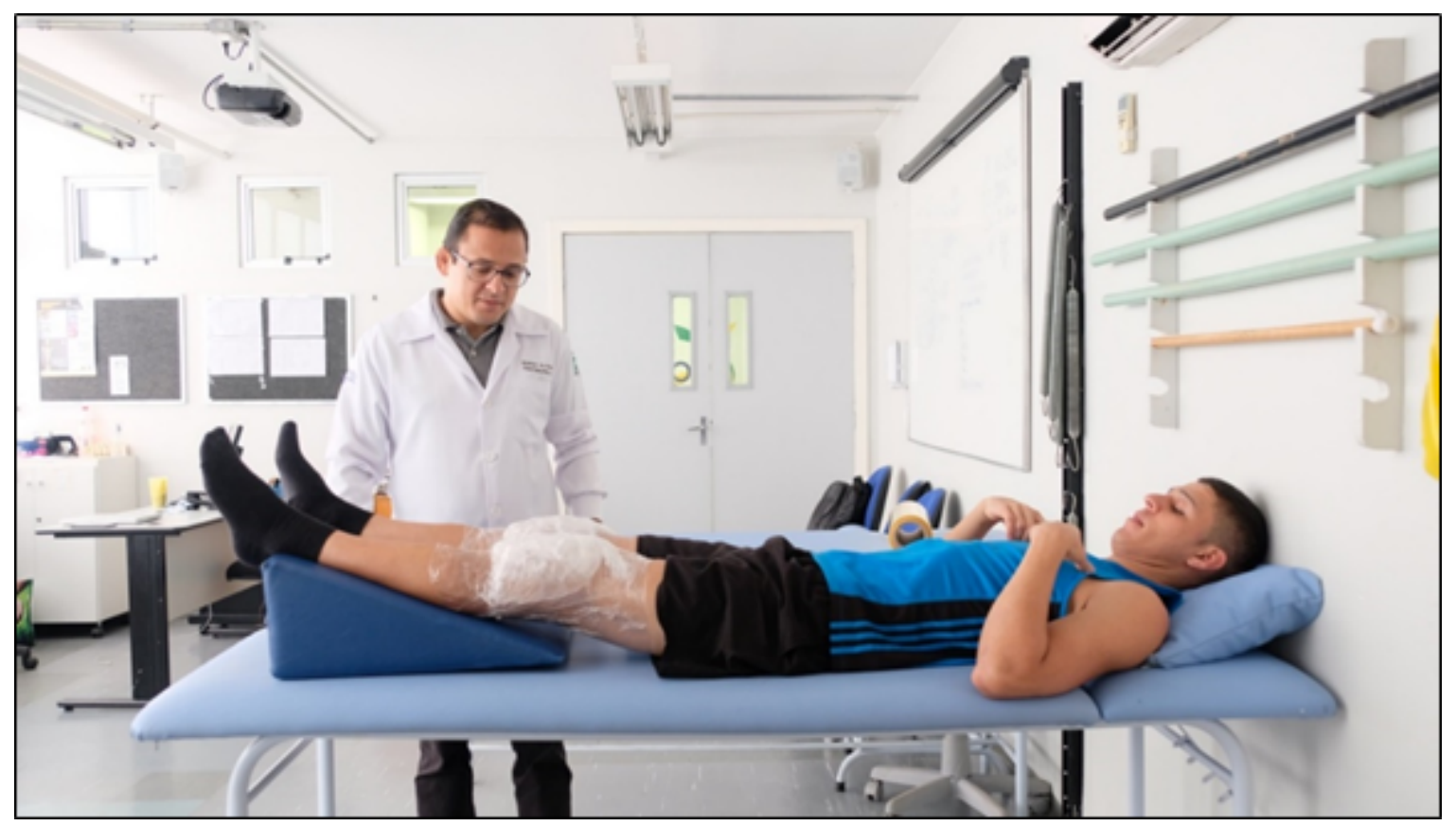

Fonte: Arquivo pessoal do autor (2019).

Figuras 14 a 16. Evolução dos pacientes ao longo do período de fisioterapia pós-operatória

\subsection{PERÍODO DE INTERVENÇÃO}

A intervenção foi feita por meio da submissão dos grupos de pesquisa a um programa de oito semanas de exercícios resistidos, a partir do final do $3^{\circ}$ mês pós-operatório, após a avaliação pré-intervenção. O GC foi mantido conforme a metodologia convencional, onde são realizados exercícios bilaterais, ou seja, com os dois membros inferiores ao mesmo tempo. Para o Gl foi adotada uma conduta alternativa, com a realização de exercícios unilaterais somente para o membro doador que, conforme citado previamente, se demonstrou como o maior afetado no que diz respeito à perda de desempenho muscular (Oliveira et al. (2004, 2006, 2009, 2014), Lobo et al. (2006, 2013, 2018) Ataides et al. (2013).

A sequência comum de intervenção está descrita abaixo e foi adotada durante todas as prescrições de exercícios resistidos do período de acompanhamento dos(as) pacientes:

- Foram realizadas no mínimo duas sessões de tratamento por semana, respeitando intervalo mínimo 48 horas entre as intervenções, de modo a possibilitar o restabelecimento do nível adequado de glicogênio muscular (Mcardle et al., 2008);

- A sequência de exercícios inclui estímulos tanto em cadeia cinética fechada como em movimentos de cadeia cinética aberta (Ellenbecker, 2009) e a ordem de execução foi ordenada por complexidade do gesto motor e número de articulações envolvidas (Fleck, 2006; Kreamer, 2009); 
- Os exercícios do GC foram: agachamento, leg press, extensão final (extensão do joelho com polia baixa), cadeira extensora e a elevação do membro estendido, ou straight leg raise;

- A sequência de exercícios do GI era semelhante, porém utilizou-se somente o membro doador: agachamento afundo (com o membro lesionado à frente), leg press, extensão final, cadeira extensora e SLR;

- As sessões foram compostas por três séries de 12 repetições em cada exercício, sendo cada repetição realizada com 2 segundos tanto na fase concêntrica, quanto na excêntrica. A progressão do programa foi conduzida do ajuste de carga, realizado com incrementos de $2 \%$ a $10 \%$ na sessão seguinte àquela em que $o$ indivíduo conseguiu realizar todas as repetições em todas as séries de um dado exercício (ACSM, 2002);

- O intervalo entre as séries foi de 1 minuto e entre os exercícios de 3 minutos (ACSM, 2002; Fleck, 2006; Kraemer, 2009);

- A carga de trabalho inicial foi definida de acordo com o teste de repetição proposto por Kraemer (2009), que permite identificar a sobrecarga adequada para especificidade do programa de exercícios resistidos sem submeter 0 aparelho locomotor ao estresse de contração máxima;

- Todas as sessões de exercícios resistidos foram precedidas por um período de aquecimento em bicicleta ergométrica com duração de 5 minutos e intensidade referente a $60 \%$ da frequência cardíaca máxima de reserva (monitorada por um oxímetro de dedo digital Onyx Nonin ${ }^{\circledR}$ ) estimada a partir da frequência cardíaca máxima predita pela idade, conforme segue: \{[(220 idade) - frequência cardíaca de repouso] $\times 0.6\}$ + frequência cardíaca de repouso (Figura 87) (Knudson, 2009; ACSM, 2009);

- Ao final de cada sessão, foram realizados alongamentos para quadríceps, isquiotibiais e panturrilha, em três séries de 30 segundos (ACSM, 2011).

Anteriormente ao início da coleta oficial, foram acompanhados 20 pacientes como pré-teste, a fim de verificar a reprodutibilidade do procedimento com os sujeitos da pesquisa. Os 10 primeiros eram pacientes saudáveis, sem histórico de lesões nos membros inferiores. Os demais correspondiam aos critérios de inclusão da amostra. Durante o período de intervenção, os pacientes foram recomendados a realizarem exclusivamente as atividades propostas. 


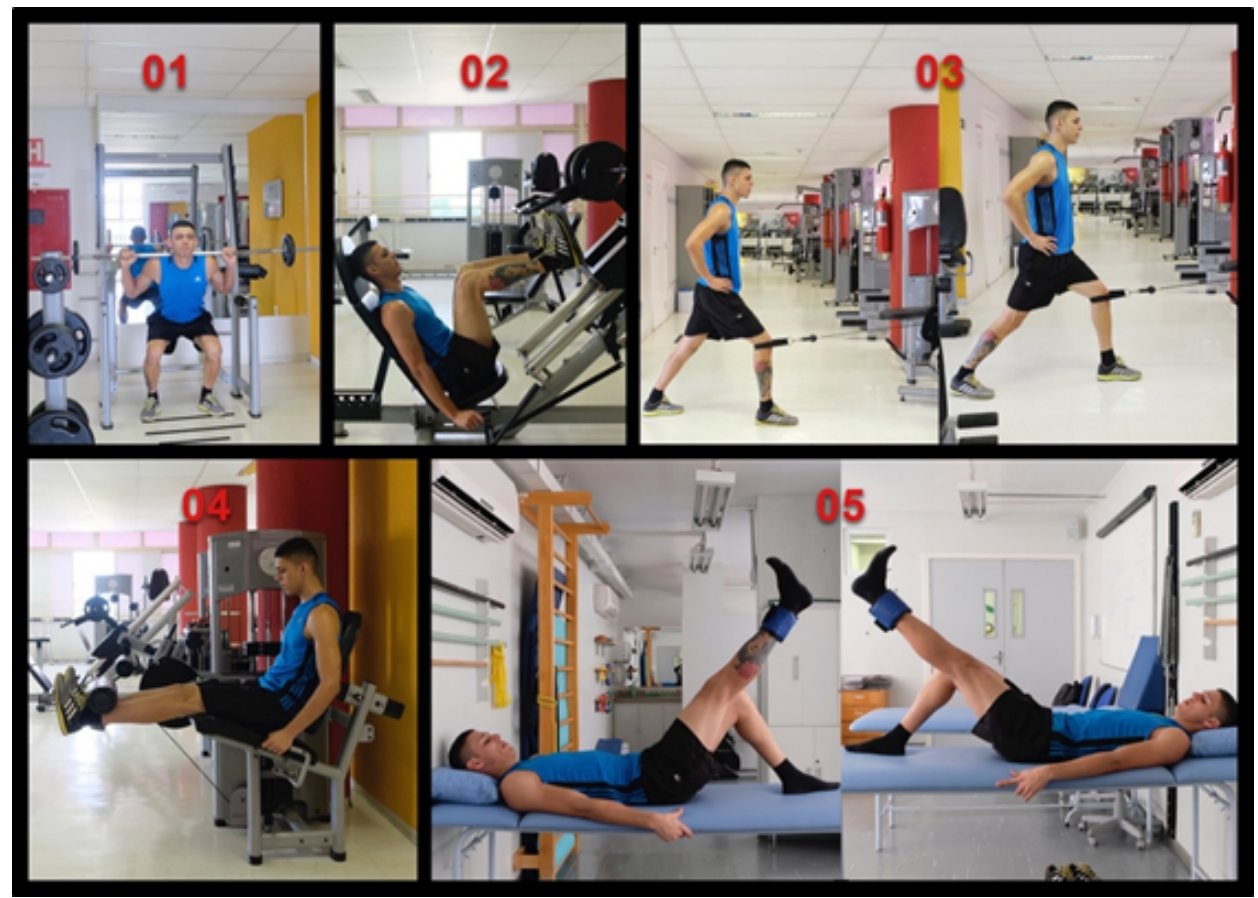

Fonte: Arquivo pessoal do autor (2019).

Figura 17. Sequência de exercícios realizados pelo Grupo Controle

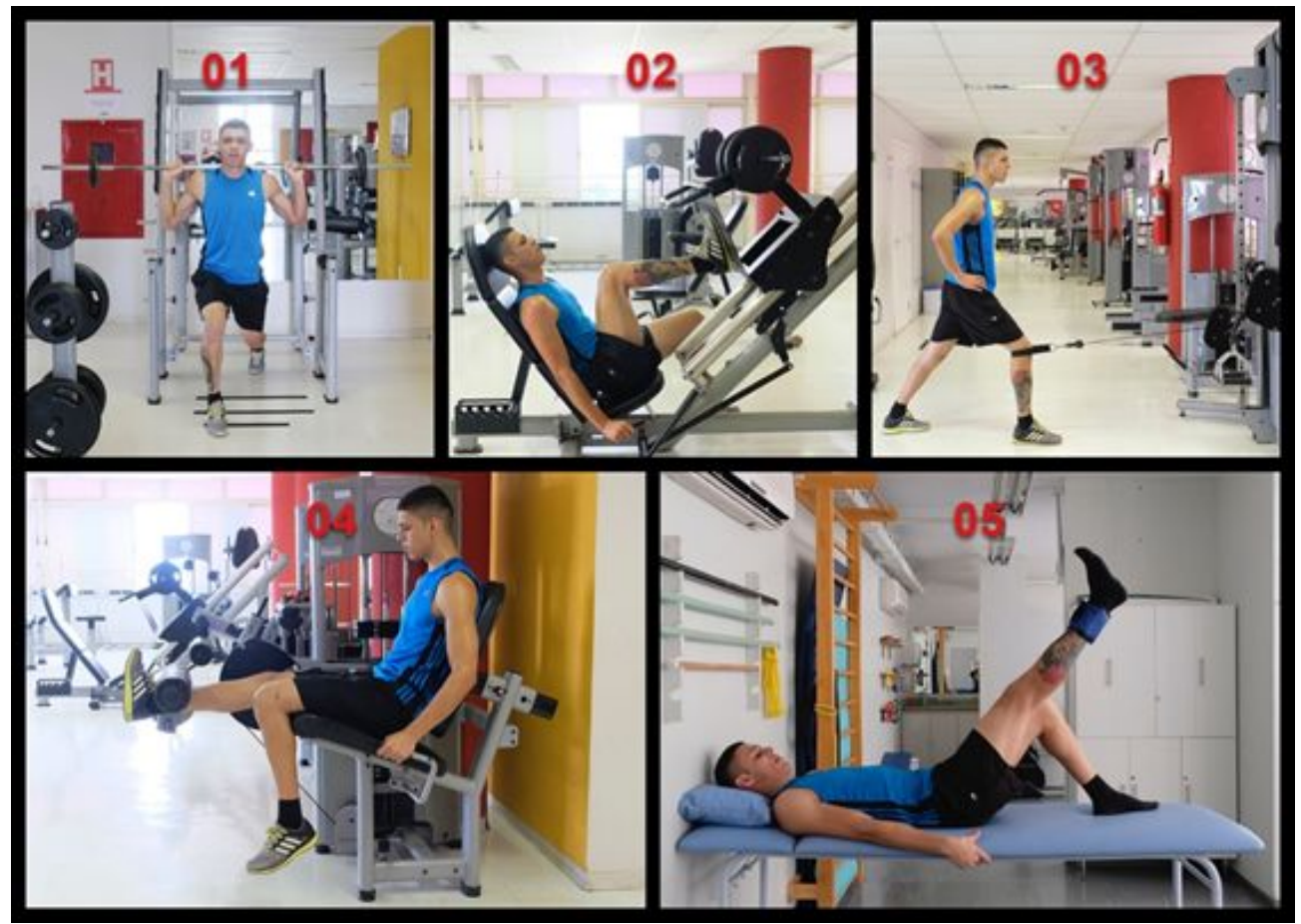

Fonte: Arquivo pessoal do autor (2019)

Figura 18. Sequência de exercícios realizados pelo Grupo Intervenção 


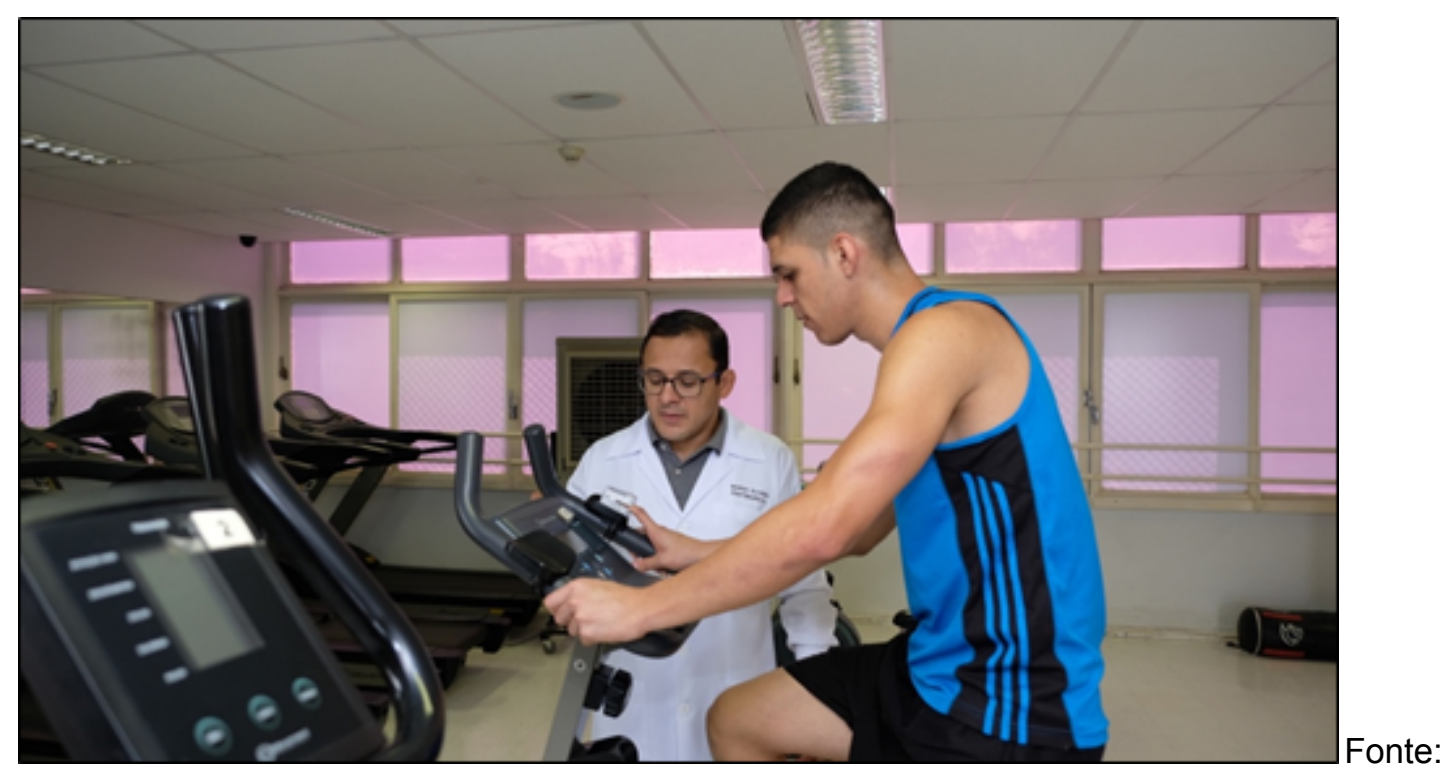

Arquivo pessoal do autor (2019).

Figura 19. Aquecimento na bicicleta ergométrica antes dos períodos de intervenção

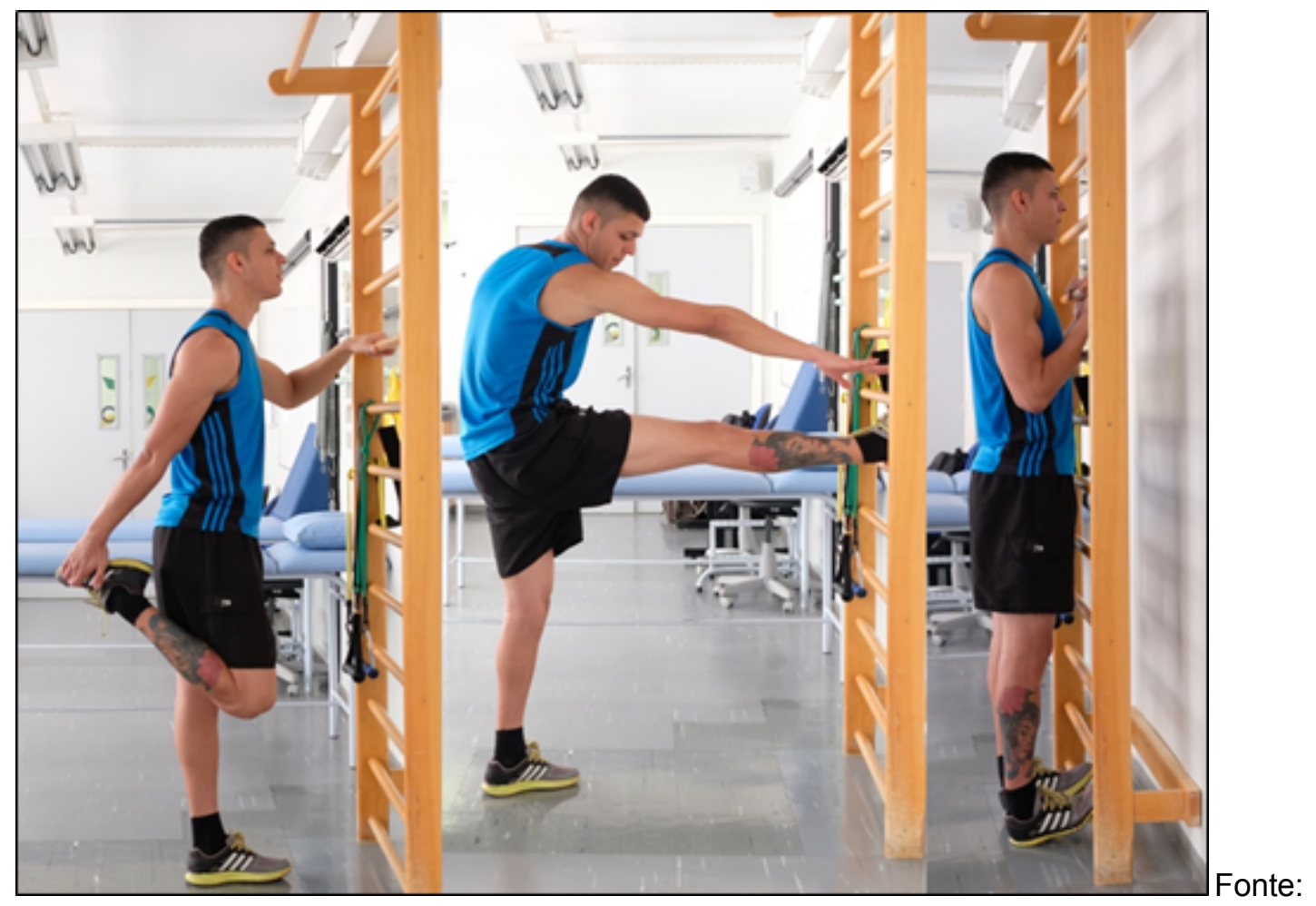

Arquivo pessoal do autor (2019).

Figura 20. Sequência de exercícios de alongamento realizados por ambos os grupos

\subsection{CRITÉRIOS DE AVALIAÇÃO}

Os(as) pacientes foram avaliados anteriormente e ao final do período de intervenção. Os procedimentos foram realizados de forma cega, por uma avaliadora independente, não envolvida com o estudo, sem vínculo empregatício com as instituições envolvidas. Era uma fisioterapeuta, 
pós-graduada em Fisioterapia Traumato-Ortopédica Funcional e Esportiva, com experiência na aplicação dos critérios utilizados e que desconhecia qualquer informação relacionada aos objetivos da pesquisa, diagnóstico dos pacientes e modo de distribuição da amostra.

Todos(as) os(as) participantes foram orientados(as) a não realizar qualquer tipo de atividade física nas 24 horas que antecederam os testes, para que houvesse descanso suficiente pré-avaliação, e usavam roupas de ginástica (camisa, short e tênis) durante os procedimentos. Os instrumentos utilizados encontravam-se calibrados de acordo com as orientações dos respectivos manuais.

Inicialmente foram feitas a identificação e anamnese incluindo, além da obtenção dos dados pessoais, histórico de lesões e queixa principal (com a aplicação da Escala Visual e Analógica de Dor - EVA), os registros do nível de atividade física, peso, estatura, pressão arterial e frequência cardíaca. Os dados foram registrados na Ficha de Avaliação do Joelho.

Tabela 1. Critérios de avaliação física realizados antes e após a intervenção com os(as) pacientes da pesquisa. Brasília, 2019.

\begin{tabular}{|c|c|c|c|}
\hline Itens avaliados & Métodos utilizado & Critérios de avaliação & Referências \\
\hline $\begin{array}{l}\text { Presença de } \\
\text { sinais } \\
\text { inflamatórios e } \\
\text { alterações no } \\
\text { trofismo da coxa. }\end{array}$ & $\begin{array}{l}\text { Inspeção, palpação } \\
\text { e perimetria }\end{array}$ & $\begin{array}{c}\text { Presença de edema, } \\
\text { aumento na temperatura } \\
\text { e hipotrofia. }\end{array}$ & $\begin{array}{l}\text { IKDC (2000) } \\
\text { Malone et al. } \\
\quad(2000) \\
\text { Magee (2005) }\end{array}$ \\
\hline $\begin{array}{l}\text { Amplitude de } \\
\text { movimento }\end{array}$ & Goniometria & $\begin{array}{l}\text { Amplitude dos } \\
\text { movimentos de flexão, } \\
\text { perda de extensão e } \\
\text { hiperextensão. }\end{array}$ & IKDC (2000) \\
\hline $\begin{array}{c}\text { Estabilidade } \\
\text { articular objetiva }\end{array}$ & $\begin{array}{l}\text { Artrometria com } \\
\text { KT1000 }\end{array}$ & $\begin{array}{l}\text { Translação anterior da } \\
\text { tíbia sobre o fêmur. }\end{array}$ & IKDC (2000) \\
\hline
\end{tabular}




\begin{tabular}{cccc}
\hline $\begin{array}{c}\text { Capacidade } \\
\text { sensório-motora }\end{array}$ & $\begin{array}{c}\text { Teste de ativação } \\
\text { do quadríceps; }\end{array}$ & $\begin{array}{c}\text { Capacidade de } \\
\text { execução e } \\
\text { dingle Hop Test; } \\
\text { Y Balance Test }\end{array}$ & Plisky et al. (2006) \\
\hline $\begin{array}{c}\text { Desempenho nos testes. } \\
\text { muscular }\end{array}$ & $\begin{array}{c}\text { Dinamometria } \\
\text { isocinética }\end{array}$ & $\begin{array}{c}\text { Pico de torque e relação } \\
\text { isquiotibiais/quadríceps }\end{array}$ & $\begin{array}{c}\text { Grindem et al. } \\
\text { (2016) }\end{array}$ \\
\hline
\end{tabular}

Fonte: Próprio autor (2019).

\subsubsection{INSPEÇÃO, PALPAÇÃO E CIRCUNFERÊNCIA DO JOELHO E COXA}

Para avaliar a presença, evolução dos sinais inflamatórios e alterações do trofismo na coxa, foram realizadas a inspeção, palpação e mensuração da circunferência da linha articular do joelho e coxa. Os procedimentos foram feitos com base em Malone et al. (2000) e Magee (2005).

\subsubsection{AVALIAÇÃO DA ADM}

A ADM foi mensurada por meio da goniometria, considerando os movimentos de flexão, quanto falta para a extensão e hiperextensão, baseadas no procedimento descrito por De Carlo e Sell (1997).

De acordo com o IKDC (2000), considera-se normal a diferença $<3^{\circ}$ para o movimento de extensão e de $0^{\circ}$ a $5^{\circ}$ para a flexão. Déficits maiores são considerados respectivamente próximo do normal $\left(6^{\circ}\right.$ a $15^{\circ} ; 3^{\circ}$ a $\left.5^{\circ}\right)$, anormal $\left(16^{\circ}\right.$ a $25^{\circ} ; 6^{\circ}$ a $\left.10^{\circ}\right)$ ou severamente anormal $\left(>25^{\circ} ;>10^{\circ}\right)$. Foram registradas as médias dos valores mensurados para cada movimento em cada membro.

\subsubsection{ESTABILIDADE ARTICULAR}

A estabilidade articular foi avaliada de forma objetiva por meio do artrômetro eletrônico KT1000 ${ }^{\mathrm{TM}}$ (MEDmetric, San Diego, CA). Foi realizado o teste de deslocamento anterior máximo (a força é aplicada por meio de uma manopla ligada ao dinamômetro) com força de 30 libras, de acordo com a metodologia indicada pelo manual do equipamento (Daniel, 1993). Foi registrado o maior valor após três tentativas. De acordo com o IKDC (2000), considera-se normal a diferença entre -1 e $2 \mathrm{~mm}$ na translação anterior da tíbia em relação ao fêmur entre os membros sadio e lesionado(operado). Diferenças de $3 \mathrm{~mm}-5 \mathrm{~mm}, 6 \mathrm{~mm}-10 \mathrm{~mm}$ e $>10 \mathrm{~mm}$ são consideradas, respectivamente, próximas do normal, anormais e severamente anormais. Foram registradas as médias dos valores mensurados em cada membro.

\subsubsection{AVALIAÇÃO SENSÓRIO-MOTORA}


Para avaliação da capacidade sensório-motora foram realizados, além do Single Hop Test, que consta no IKDC, o Teste de Ativação do Quadríceps e o Y Balance Test, recomendados para o acompanhamento de pacientes que sofreram a lesão ou foram submetidos à RLCA (Plisky, 2006).

De modo a padronizar a execução do Single Leg Hop Test e do Y Balance Test para todos os pacientes, foi utilizado o Sistema de Avaliação Sensório-Motora Espaço Gabanini ${ }^{\circledR}$, que é constituído por um conjunto de tábuas numeradas que possibilitam a disposição em linha reta para o primeiro teste e a adaptação em nas três direções, de modo que as posteriores fiquem separadas por um ângulo de 90 graus e afastadas da haste anterior em ângulos de 135 graus para o segundo teste. Além disso, foram realizadas três repetições de cada teste para familiarização com o equipamento e maior confiabilidade nas medidas obtidas. Adotou-se avaliar primeiramente o MD e, em seguida, o MR. Foram registradas as médias dos valores mensurados para cada movimento em cada membro.

\subsubsection{AVALIAÇÃO DO DESEMPENHO MUSCULAR}

A avaliação do desempenho muscular representou a última etapa do exame físico. Foi realizada com o dinamômetro isocinético Biodex Multi-joint System 4 Pro ${ }^{\circledR}$ (Biodex Medical Systems Inc., Shirley, NY, USA), com base na metodologia indicada pelo manual do fabricante (Biodex, 1998).

Os dados utilizados foram:

- Pico de torque (Peak Torque) de extensão: representa a força muscular máxima desenvolvida em qualquer posição da amplitude de movimento. É obtido em Newton/metro (Nm);

- Relação Isquiotibiais/Quadríceps (Agon/Antag Ratio): representa o percentual de força da musculatura extensora, representada pela musculatura flexora. É calculada dividindo-se os valores de torque do grupo muscular mais fraco isquiotibiais, pelo do grupo mais forte - quadríceps.

Foram apresentadas as médias dos valores mensurados para cada parâmetro em cada membro. Espera-se a diferença máxima $£ 10 \%$ entre os membros para que o resultado seja considerado normal (Grindem et al. 2016). A relação I/Q deverá estar em 50\% a 70\% (Andrade et al., 2012 Evangelidis et al., 2016).

\subsubsection{QUESTIONÁRIOS FUNCIONAIS}

Para avaliação subjetiva da evolução clínica dos pacientes, foram aplicados o Questionário de Lysholm (QL) e a Escala de Atividades de Vida Diária (EAVD). São instrumentos que caracterizam a resposta do paciente a respeito dos sintomas e da funcionalidade do segmento lesionado. Foram traduzidos e validados para a língua portuguesa com propriedades de medida e confiabilidade (Peccin, Ciconelli e Cohen, 2006; Nigri, 2007). Para análise dos resultados, foram apresentadas a pontuação no QL e na EAVD, a nota atribuída à percepção geral, a classificação funcional e a classificação do nível de atividade. 


\subsection{ANÁLISE DOS DADOS E DESFECHO DA PESQUISA}

A análise estatística foi processada pelo software estatístico $\mathrm{SAS}^{\circledR}$ System, versão 6.11 (SAS Institute, Inc., Cary, North Carolina).

Inicialmente foi apresentada a análise descritiva dos dados, com a finalidade de definir um panorama geral dos participantes a partir das suas características gerais - identificação e dados da anamnese. Foram apresentados na forma de tabelas os dados observados, expressos pela mediana e intervalo interquartílico (IIQ: Q1 - Q3) para dados numéricos e frequência e porcentagem para dados categóricos.

A análise inferencial foi composta na comparação entre dados pareados pelo teste dos postos sinalizados de Wilcoxon para dados numéricose pelo teste de McNemar corrigido para dados categóricos.

A comparação entre os grupos foi analisada pelo teste de Mann-Whitney para dados numéricos e teste de qui-quadrado $\left(X^{2}\right)$ ou exato de Fisher para dados categóricos. Foram utilizados métodos não paramétricos, pois os dados não apresentaram distribuição normal (Gaussiana), devido à rejeição da hipótese de normalidade segundo o teste de Shapiro-Wilk, em pelo menos um grupo e (ou) momento. O critério de determinação de significância adotado foi o nível de $5 \%$.

\subsection{LOCAIS DE COLETA DOS DADOS}

Os procedimentos da pesquisa foram realizados no Hospital HOME e no Centro de Atendimento Comunitário do Centro Universitário de Brasília - UniCEUB, que autorizaram formalmente as atividades por meio da assinatura do Termo de Ciência Institucional, que foi encaminhado ao CEP/UNIFESP.

\subsection{CRONOGRAMA DA PESQUISA}

Inicialmente o Projeto de Pesquisa foi submetido ao Comitê de Ética (CEP) da Universidade Federal de São Paulo / Escola Paulista de Medicina (UNIFESP / EPM). Em seguida, foi aprovado junto à Banca de Avaliação do Programa de Pós-Graduação em Saúde Baseada em Evidências. Durante 12 meses, 20 indivíduos foram submetidos ao pré-teste, passando por todas as fases de intervenção, o que permitiu as adequações do projeto, que então foi registrado junto à Plataforma Brasileira de Ensaios Clínicos. Por fim, foram iniciadas as coletas oficiais até maio do presente ano, prazo final para a intervenção dos últimos pacientes e obtenção do número amostral.

Ao todo, a pesquisa (avaliações e intervenções) teve a duração de 29 meses, sendo o período restante destinado à elaboração da discussão dos resultados, conclusões do estudo. O cronograma em etapas das atividades está descrito abaixo e representado por meio do Quadro 1:

Etapa 1 - Período de pré-testes e organização da logística de trabalho;

- Etapa 2 - Registro na Plataforma Brasileira de Ensaios Clínicos e início do período de intervenção;

Etapa 3 - Período de coletas;

- Etapa 4 - Término da coleta; 
·Etapa 5 - Análise dos resultados e redação da tese.

Quadro 1. Sequência de etapas da pesquisa. Brasília, 2019

\begin{tabular}{|c|c|c|c|c|c|c|c|c|c|c|c|c|}
\hline \multicolumn{13}{|c|}{2016 e 2017} \\
\hline Etapas & $\begin{array}{c}\text { Mês } \\
1\end{array}$ & $\begin{array}{c}\text { Mês } \\
2\end{array}$ & $\begin{array}{c}\text { Mês } \\
3\end{array}$ & $\begin{array}{c}\text { Mês } \\
4\end{array}$ & $\begin{array}{c}\text { Mês } \\
5\end{array}$ & $\begin{array}{c}\text { Mês } \\
6\end{array}$ & $\begin{array}{c}\text { Mês } \\
7\end{array}$ & $\begin{array}{c}\text { Mês } \\
8\end{array}$ & $\begin{array}{c}\text { Mês } \\
9\end{array}$ & $\begin{array}{c}\text { Mês } \\
10\end{array}$ & $\begin{array}{c}\text { Mês } \\
11\end{array}$ & $\begin{array}{c}\text { Mês } \\
12\end{array}$ \\
\hline 1 & 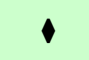 & 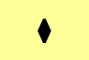 & 1 & $\checkmark$ & 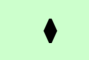 & 1 & 1 & 1 & $\checkmark$ & 1 & $\bullet$ & $\bullet$ \\
\hline \multicolumn{13}{|c|}{2018} \\
\hline Etapas & $\begin{array}{c}\text { Mês } \\
1\end{array}$ & $\begin{array}{c}\text { Mês } \\
2\end{array}$ & $\begin{array}{c}\text { Mês } \\
3\end{array}$ & $\begin{array}{c}\text { Mês } \\
4\end{array}$ & $\begin{array}{c}\text { Mês } \\
5\end{array}$ & $\begin{array}{c}\text { Mês } \\
6\end{array}$ & $\begin{array}{c}\text { Mês } \\
7\end{array}$ & $\begin{array}{c}\text { Mês } \\
8\end{array}$ & $\begin{array}{c}\text { Mês } \\
9\end{array}$ & $\begin{array}{c}\text { Mês } \\
10\end{array}$ & $\begin{array}{c}\text { Mês } \\
11\end{array}$ & $\begin{array}{c}\text { Mês } \\
12\end{array}$ \\
\hline 2 & 1 & & & & & & & & & & & \\
\hline 3 & 1 & 1 & 1 & 1 & 1 & 1 & 1 & 1 & $\checkmark$ & 1 & $\bullet$ & 1 \\
\hline \multicolumn{13}{|c|}{2019} \\
\hline Etapas & $\begin{array}{c}\text { Mês } \\
1\end{array}$ & $\begin{array}{c}\text { Mês } \\
2\end{array}$ & $\begin{array}{c}\text { Mês } \\
\mathbf{3}\end{array}$ & $\begin{array}{c}\text { Mês } \\
4\end{array}$ & $\begin{array}{c}\text { Mês } \\
5\end{array}$ & $\begin{array}{c}\text { Mês } \\
6\end{array}$ & $\begin{array}{c}\text { Mês } \\
7\end{array}$ & $\begin{array}{c}\text { Mês } \\
8\end{array}$ & $\begin{array}{c}\text { Mês } \\
9\end{array}$ & $\begin{array}{c}\text { Mês } \\
10\end{array}$ & $\begin{array}{c}\text { Mês } \\
11\end{array}$ & $\begin{array}{c}\text { Mês } \\
12\end{array}$ \\
\hline 3 & 1 & 1 & 1 & 1 & & & & & & & & \\
\hline 4 & & & & & 1 & & & & & & & \\
\hline 5 & & & & & 1 & $\checkmark$ & & & & & & \\
\hline
\end{tabular}

\section{RESULTADOS}

A amostra final foi formada por 88 pacientes, distribuídos(as) igualmente em grupos controle (GC) e intervenção (Gl). Ao longo do desenvolvimento da pesquisa, 9 pacientes foram excluídos(as), sendo 2 por dor na área doadora (GC), 4 por desistência (3 do GI e 1 do GC) e 3 por não cumprirem os procedimentos propostos 
(2 do $\mathrm{Gl}$ e 1 do GC). O fluxograma de fases da pesquisa pode ser visualizado na figura abaixo.

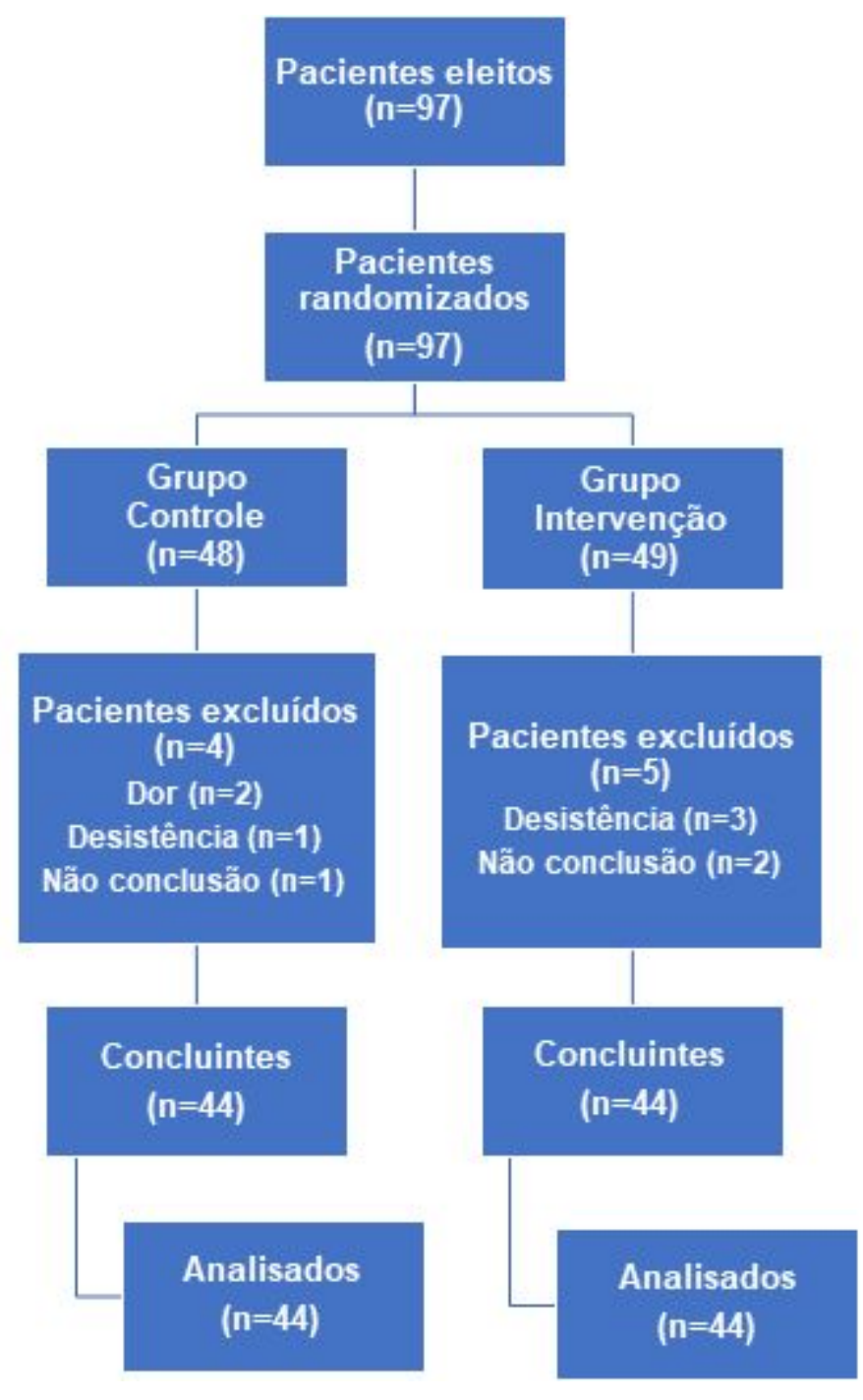

Figura 21. Fluxograma de progresso do ensaio clínico demonstrando as fases percorridas pelos dois grupos de pesquisa segundo CONSORT. Brasília, 2019.

As características antropométricas e demográficas no baseline estão apresentadas na tabela 2 abaixo. Ao total são 59 homens (67\%) e 29 mulheres (33\%). Em ambos os grupos a predominância é do gênero masculino. No GI são 28 homens e 16 mulheres, enquanto no $G C$ são 31 homens e 13 mulheres. Observou-se que não existe diferença significativa nas variáveis basais entre os dois grupos em estudo.

Tabela 2. Distribuição da amostra e comparação entre os grupos de pesquisa para as variáveis gênero, idade, peso, estatura, índice de massa corporal, dominância, membros doador e receptor. Brasília, 2019. 


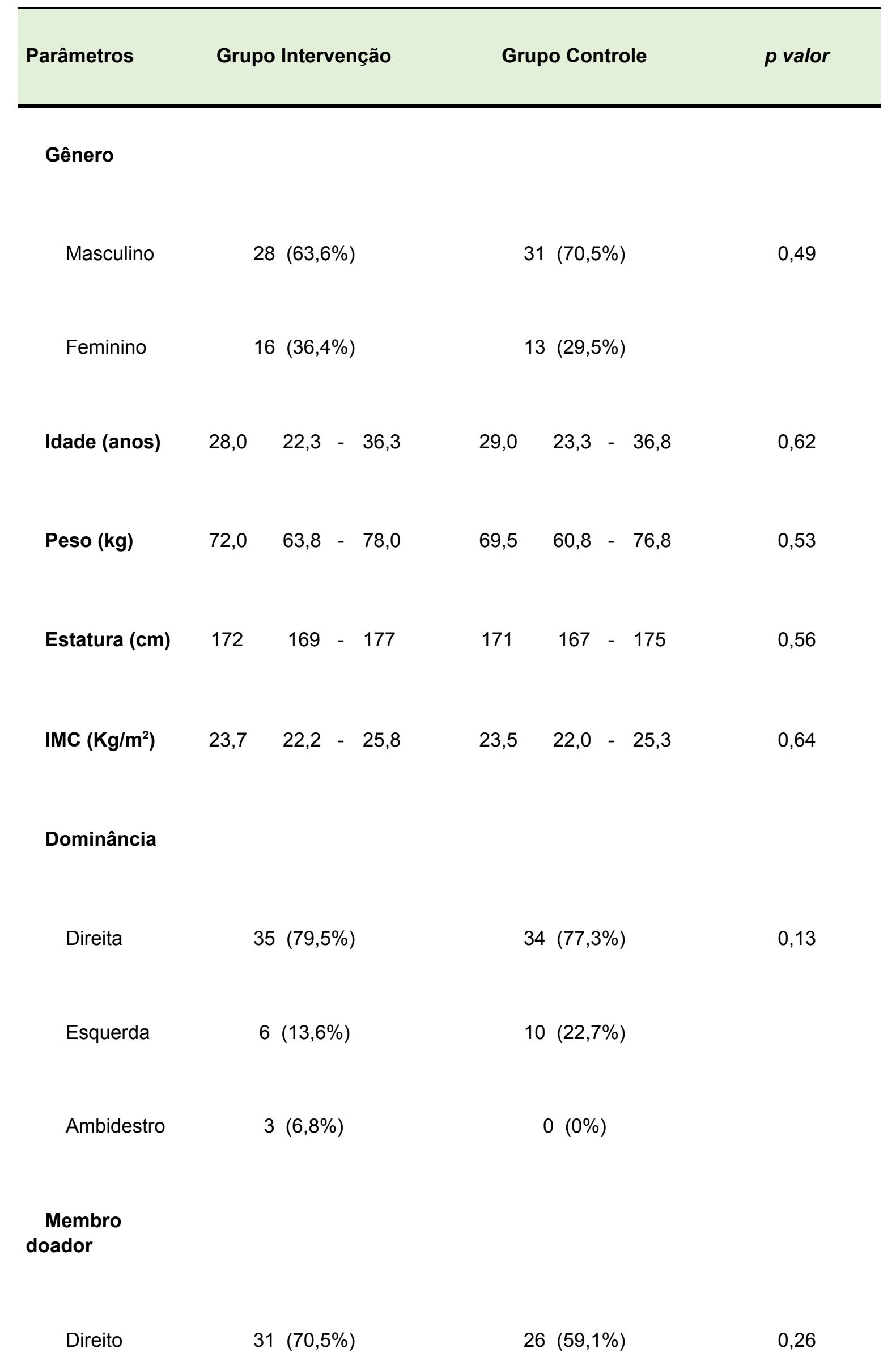



Esquerdo
$13(29,5 \%)$
$18(40,9 \%)$

\section{Membro \\ receptor}
Direita
$13(29,5 \%)$
$18(40,9 \%)$
0,26
Esquerda
$31(70,5 \%)$
$26(59,1 \%)$

Os dados numéricos foram expressos pela mediana e intervalo interquartílico (IIQ: Q1-Q3) e comparados pelo teste de Mann-Whitney e os dados categóricos foram expressos pela frequência e porcentagem e comparados pelo teste de $x^{2}$ ou exato de Fisher.

As tabelas 3 e 4 fornecem a análise descritiva dos parâmetros de simetria no pré e pós-intervenção e o correspondente nível descritivo ( $p$ valor) do teste estatístico no interior de cada grupo. Os parâmetros de simetria foram calculados a partir das diferenças absolutas das medidas entre o membro receptor (MR) e membro doador (MD): MR-MD. Observou-se, no grupo intervenção, variação significativa, ao nível de $5 \%$, do pré para pós-intervenção em todos os parâmetros de simetria, exceto na avaliação da estabilidade articular objetiva - KT-1000 ${ }^{\mathrm{TM}}(p=$ $0,75)$, sendo que todos os parâmetros apresentaram redução/queda pós-intervenção (Tabela 3).

Tabela 3. Análise descritiva dos parâmetros de simetria no pré e pós-intervenção e o correspondente nível descritivo ( $p$ valor) do teste estatístico no Grupo Intervenção. Brasília, 2019

\begin{tabular}{l}
$\begin{array}{l}\text { Simetria } \\
\text { parâmetros }\end{array}$ \\
\hline Grupo Intervenção
\end{tabular}

\section{Edema}




\begin{tabular}{|c|c|c|c|}
\hline MR & $16(36,4 \%)$ & $2(4,5 \%)$ & $<0,001$ \\
\hline${ }_{M R}$ manteve de MD p/ & $23(52,2 \%)$ & $42(95,5 \%)$ & \\
\hline $\begin{array}{l}\text { desapareceu de } \\
\text { MD p/MR }\end{array}$ & $5(11,4 \%)$ & $0(0 \%)$ & \\
\hline $\begin{array}{l}\text { Diminuição } \\
\text { trofismo }\end{array}$ & & & \\
\hline MR ${ }^{\text {apareceu de MD p/ }}$ & $11(25,0 \%)$ & $3(6,8 \%)$ & $<0,001$ \\
\hline MR manteve de MD p/ & $13(29,5 \%)$ & $35(79,6 \%)$ & \\
\hline $\begin{array}{l}\text { desapareceu de } \\
\text { MD p/MR }\end{array}$ & $20(45,5 \%)$ & $6(13,6 \%)$ & \\
\hline $\begin{array}{l}\text { Aumento } \\
\text { temperatura }\end{array}$ & & & \\
\hline MR $\quad$ apareceu de MD p/ & $7(15,9 \%)$ & $3(6,8 \%)$ & 0,007 \\
\hline $\begin{array}{l}\text { manteve de MD } \mathrm{p} / \\
\mathrm{MR}\end{array}$ & $25(56,8 \%)$ & $39(88,7 \%)$ & \\
\hline $\begin{array}{l}\text { desapareceu de } \\
\text { MD p/ MR }\end{array}$ & $12(27,3 \%)$ & $2(4,5 \%)$ & \\
\hline
\end{tabular}




\begin{tabular}{|c|c|c|c|c|c|c|c|c|}
\hline ADM & de & $-2,00$ & $-3,0$ & $-0,2$ & 0,00 & 0,00 & - $\quad 0,00$ & $<0,001$ \\
\hline hiperextensão & & & 0 & 5 & & & & \\
\hline
\end{tabular}

\begin{tabular}{|c|c|c|c|c|c|c|c|}
\hline ADM de flexão & $-2,00$ & $\begin{array}{r}-4,7 \\
5\end{array}$ & $-\quad 0,00$ & 0,00 & $\begin{array}{r}-1,0 \\
0\end{array}$ & - $\quad 0,00$ & $<0,001$ \\
\hline
\end{tabular}

$\begin{array}{llllllllll}\text { Perimetria ao nível da } & 0,75 & 0,20 & - & 1,20 & 0,50 & 0,00 & - & 0,68 & \mathbf{0 , 0 1 8}\end{array}$

LA

$\begin{array}{lrrrrrr}\text { Perimetria a 10cm } \quad 1,00 & 0,73 \quad-\quad 2,00 & -0,50 & -0,5 & - & 0,00 & <\end{array}$

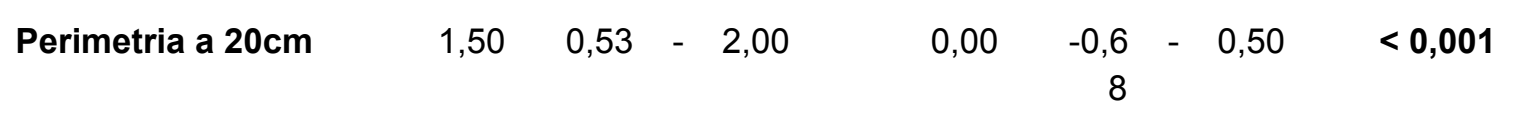

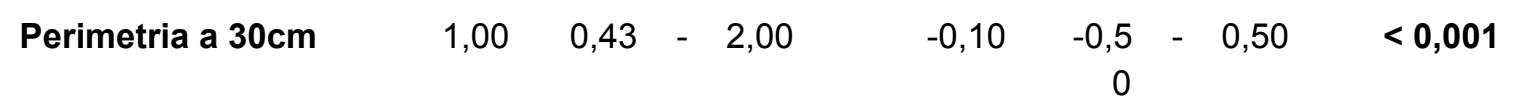

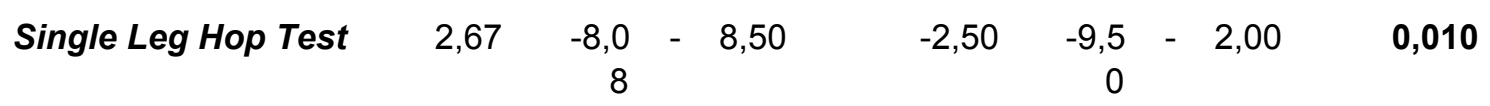

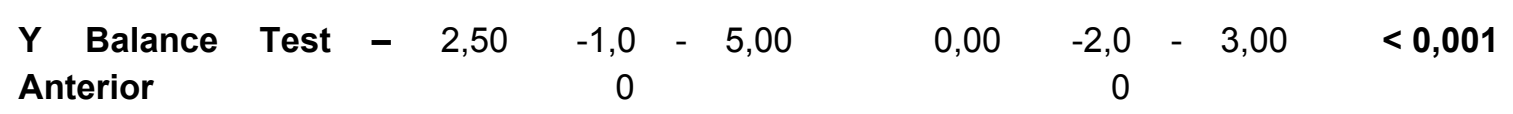

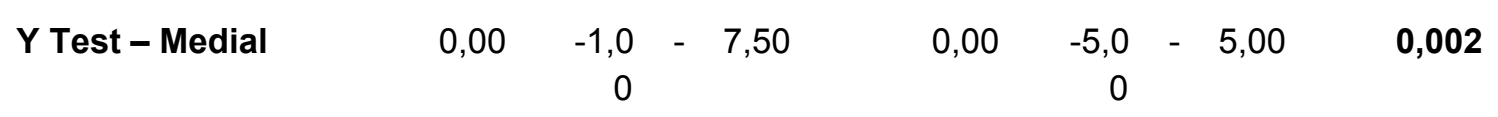

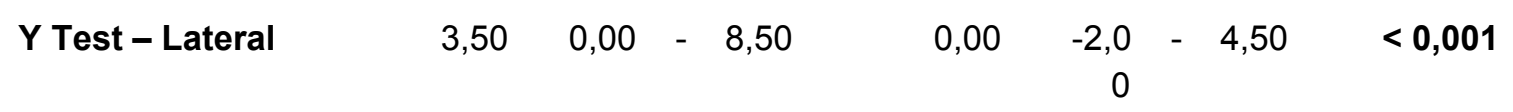

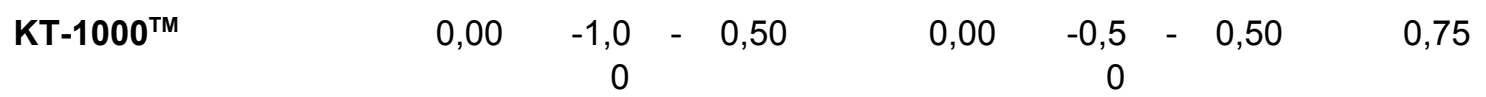


Relação I/Q

$-13,2-16,--10$,

$-4,30$

$-6,2--3,0$

$<0,001$

90

0

Pico de torque de $24,4 \quad 16,9 \quad-\quad 32,9$

8,00

$3,55-15,0$

$<0,001$

extensão

Os dados numéricos foram expressos pela mediana e intervalo interquartílico (IIQ: Q1-Q3) e comparados pelo teste dos postos sinalizados de Wilcoxon e os dados categóricos foram expressos pela frequência e porcentagem e comparados pelo teste de McNemar corrigido.

No grupo controle também houve variação significativa em todos os parâmetros de simetria, exceto na avaliação com KT-1000 ${ }^{\mathrm{TM}}(p=0,38)$, sendo que alguns parâmetros apresentaram queda (edema, trofismo, alteração de temperatura, ADM de hiperextensão, flexão, perimetria ao nível da LA e relação I/Q) e outros apresentaram aumento (perimetria nos níveis 10, 20 e 30cm, Single Leg HopTest, Y Test em todas as direções e pico de torque de extensão) pós-intervenção (Tabela 4).

Tabela 4. Análise descritiva dos parâmetros de simetria no pré e pós-intervenção e o correspondente nível descritivo ( $p$ valor) do teste estatístico no Grupo Controle. Brasília, 2019

\begin{tabular}{llll}
\hline $\begin{array}{l}\text { Simetria } \\
\text { parâmetros }\end{array}$ & dos Pré-intervenção & Pós-intervenção & \\
\hline \\
Grupo Controle
\end{tabular}

\section{Edema}

apareceu de MD p/

$13(29,5 \%)$

$1(2,3 \%)$

$<0,001$ MR

manteve de MD p/

$22(50,0 \%)$

$43(97,7 \%)$ MR 


\begin{tabular}{ll}
\multicolumn{1}{l}{ desapareceu } & de \\
MD p/MR & \\
$\begin{array}{l}\text { Diminuição } \\
\text { trofismo }\end{array}$ & do
\end{tabular}

trofismo

\begin{tabular}{|c|c|c|}
\hline MR & $1(2,3 \%)$ & $0(0 \%)$ \\
\hline MR manteve de MD p/ & $21(47,7 \%)$ & $2(4,5 \%)$ \\
\hline $\begin{array}{l}\text { desapareceu de } \\
\text { MD p/MR }\end{array}$ & $22(50,0 \%)$ & $42(95,5 \%)$ \\
\hline
\end{tabular}

\section{Aumento da \\ temperatura}

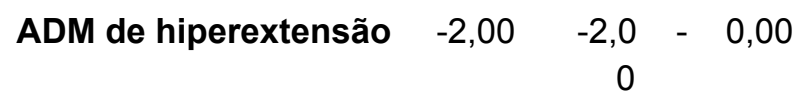

ADM de flexão
$0(0 \%)$
$9(20,5 \%)$ 


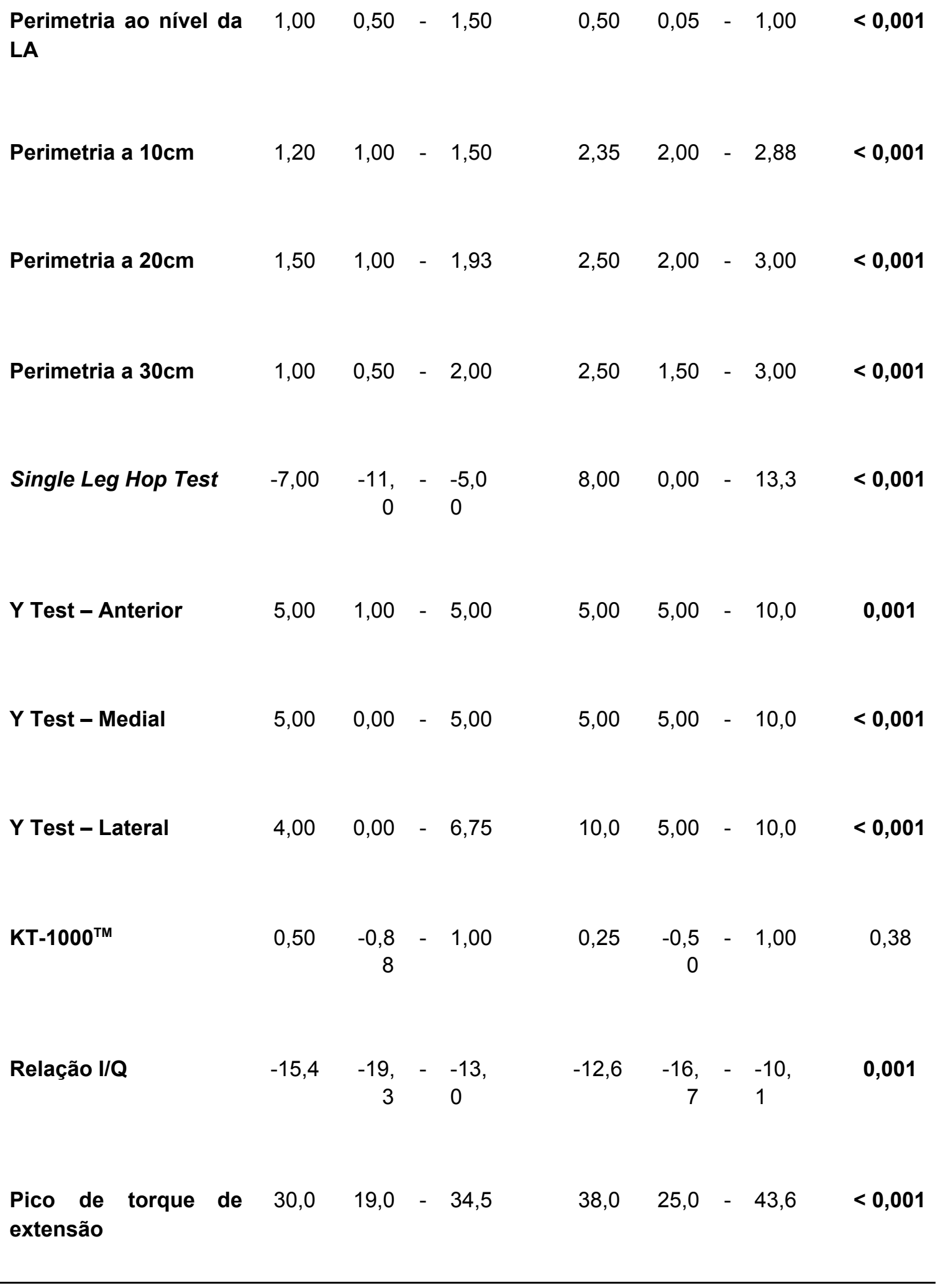

Os dados numéricos foram expressos pela mediana e intervalo interquartílico (IIQ: Q1-Q3) e comparados pelo teste dos postos sinalizados de Wilcoxon e os dados categóricos foram expressos pela frequência e porcentagem e comparados pelo teste de McNemar corrigido. 
A tabela 5 fornece a descritiva dos deltas dos parâmetros de simetria (pós-pré) segundo o grupo (intervenção e controle) e o correspondente nível descritivo ( $p$ valor) do teste estatístico. Os deltas dos parâmetros de simetria foram calculados a partir das diferenças absolutas entre os momentos pré e pós-intervenção (pós-pré).

Tabela 5. Deltas dos parâmetros de simetria (pós-pré) segundo o grupo (intervenção e controle) e o correspondente nível descritivo ( $p$ valor) do teste estatístico. Brasília, 2019

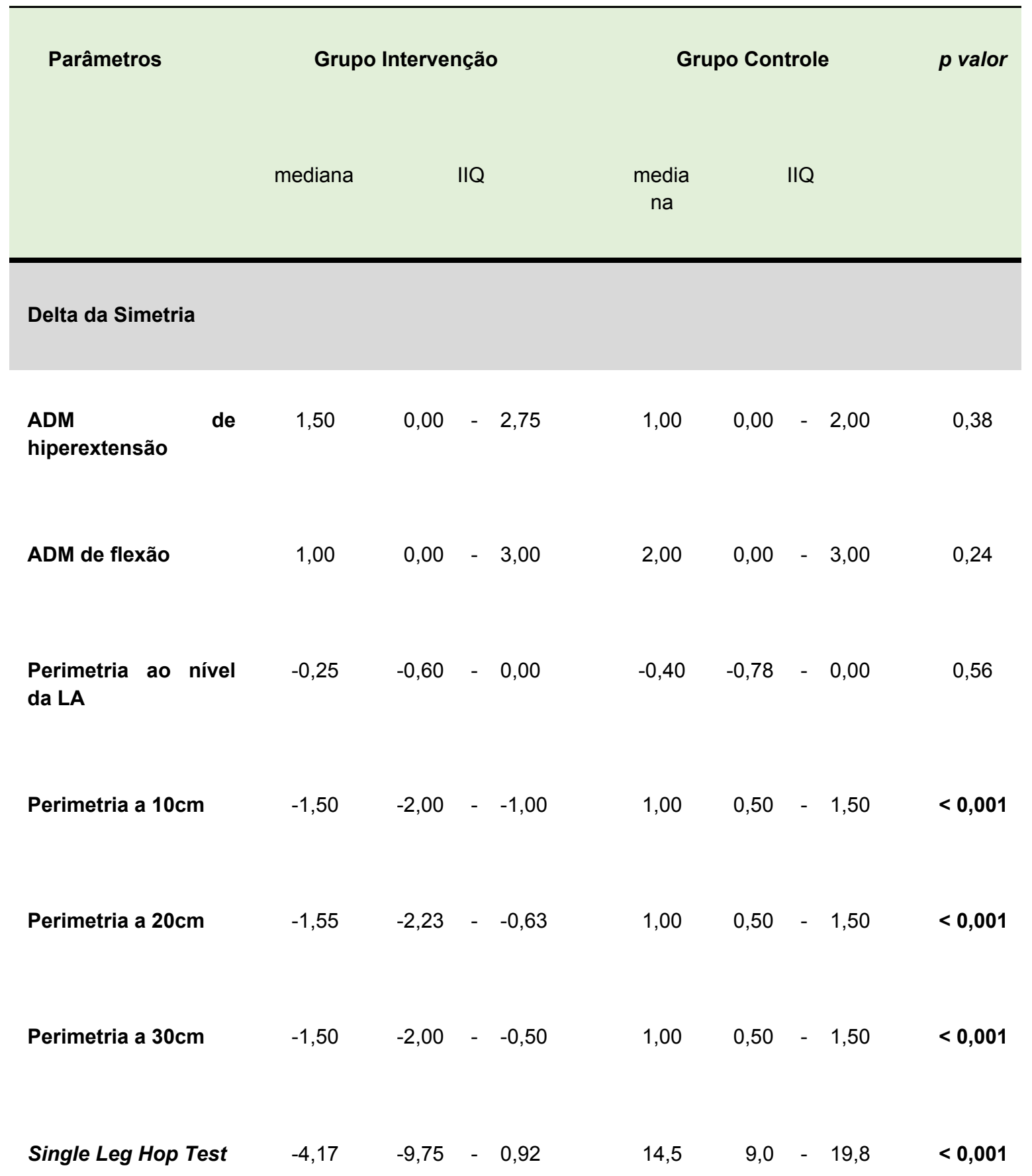




\begin{tabular}{|c|c|c|c|c|c|c|c|}
\hline Y Test - anterior & $-0,50$ & $-4,00$ & 0,00 & 0,00 & 0,00 & - 5,00 & $<0,001$ \\
\hline Y Test - medial & $-0,50$ & $-5,00$ & $-\quad 0,75$ & 2,00 & 0,00 & $-\quad 5,00$ & $<0,001$ \\
\hline Y Test - lateral & $-2,50$ & $-5,00$ & 0,00 & 5,00 & 0,00 & $-8,00$ & $<0,001$ \\
\hline $\mathrm{KT}-1000^{\mathrm{TM}}$ & 0,00 & 0,00 & - $\quad 0,00$ & 0,00 & 0,00 & 0,00 & 0,89 \\
\hline Relação I/Q & 9,00 & 4,03 & $\begin{array}{l}-11,8 \\
5\end{array}$ & 4,35 & $-0,15$ & - 7,10 & $<0,001$ \\
\hline $\begin{array}{l}\text { Pico de torque de } \\
\text { extensão }\end{array}$ & $-13,9$ & $-20,7$ & $-\quad-9,8$ & 8,5 & 4,9 & - 12,0 & $<0,001$ \\
\hline
\end{tabular}

IIQ: Intervalo Interquartílico (Q1-Q3). Teste de Mann-Whitney.

Delta da simetria corresponde a variação absoluta do pré para pós-intervenção: pós-pré.

Foi possível observar uma diferença estatisticamente significante no delta da simetria em quase todos parâmetros, exceto na $\operatorname{ADM}$ de hiperextensão $(p=0,38)$, flexão $(p=0,24)$, na perimetria ao nível da LA $(p=0,56)$ e na avaliação com $\mathrm{KT}-1000^{\mathrm{TM}}(p=0,89)$. Os grupos mostraram evolução diferenciada nos seguintes parâmetros: perimetria a 10, 20 e $30 \mathrm{~cm}$, Single Leg Hop Test, Y Test - anterior, medial e lateral, relação $I / Q$ e pico de torque de extensão. Nestes, houve um aumento da simetria no Gl em relação ao GC após o período de intervenção (Tabela 5).

A tabela 6 fornece a descritiva dos parâmetros subjetivos no pré e pós-intervenção e o correspondente nível descritivo ( $p$ valor) do teste estatístico no interior de cada grupo.

Tabela 6. Comparação entre os momentos pré e pós-intervenção no interior dos grupos para os os parâmetros subjetivos - Escala Visual Analógica de dor (EVA), Questionário de Lysholm e Escala de Atividades de Vida Diária (EAVD). Brasília, 2019 


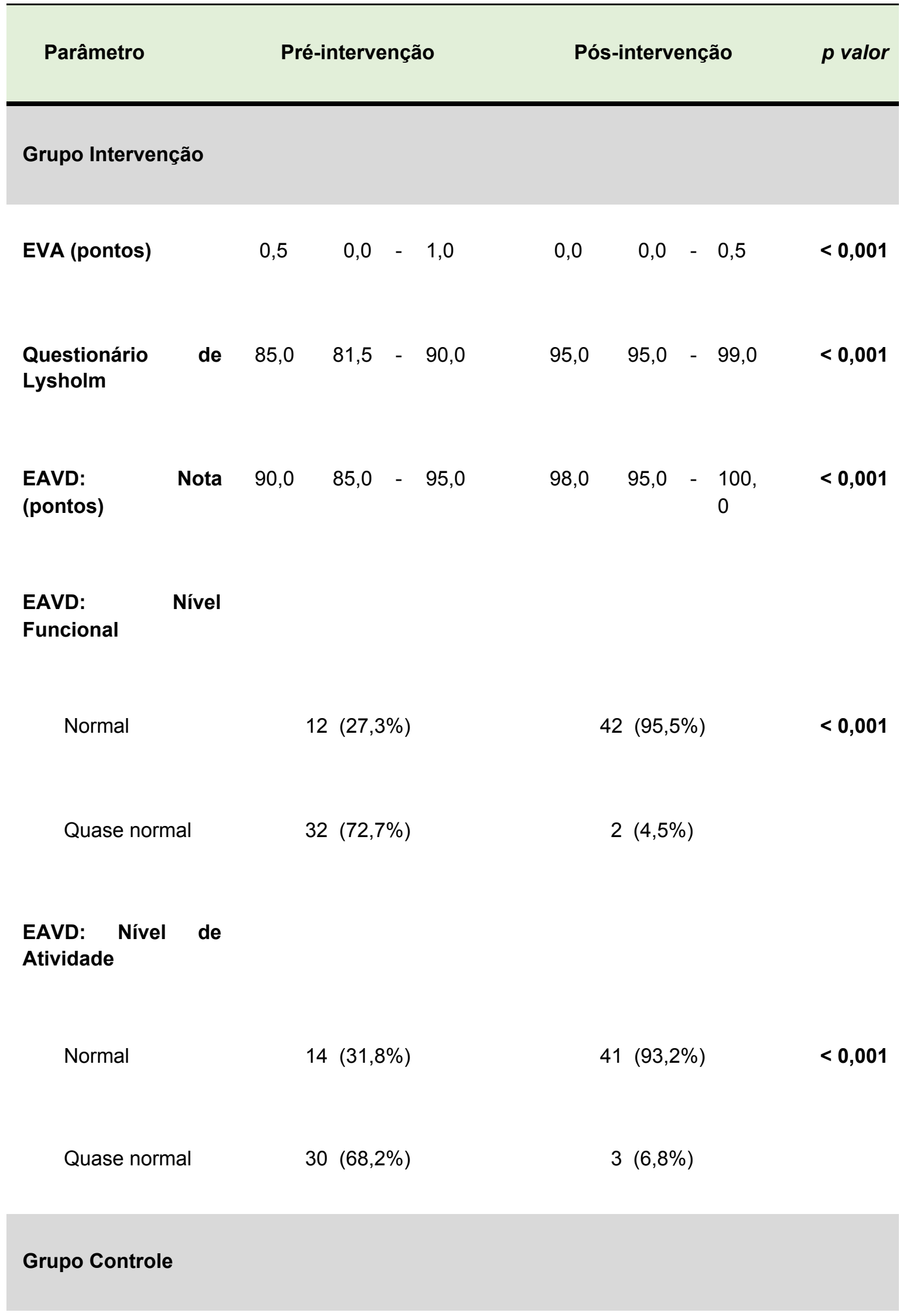




\begin{tabular}{|c|c|c|c|c|c|c|c|c|c|c|}
\hline EVA (pontos) & & 1,0 & 0,0 & - & 1,9 & 0,5 & 0,0 & - & 1,0 & $<0,001$ \\
\hline $\begin{array}{l}\text { Questionário } \\
\text { Lysholm }\end{array}$ & de & 90,0 & 85,0 & - & 90,0 & 94,5 & 94,0 & - & 95,0 & $<0,001$ \\
\hline $\begin{array}{l}\text { EAVD: } \\
\text { (pontos) }\end{array}$ & Nota & 90,0 & 86,3 & - & 95,0 & 95,0 & 95,0 & - & 95,0 & $<0,001$ \\
\hline $\begin{array}{l}\text { EAVD: } \\
\text { Funcional }\end{array}$ & Nível & & & & & & & & & \\
\hline Normal & & \multicolumn{4}{|c|}{$10(22,7 \%)$} & \multicolumn{4}{|c|}{$42(95,5 \%)$} & $<0,001$ \\
\hline Quase nor & & \multicolumn{4}{|c|}{$34(77,3 \%)$} & \multicolumn{4}{|c|}{$2(4,5 \%)$} & \\
\hline
\end{tabular}

EAVD: Nível de Atividade

Normal

Quase normal
$15(34,1 \%)$

$29(65,9 \%)$
$41(93,2 \%)$

$<0,001$

$3(6,8 \%)$

Os dados numéricos foram expressos pela mediana e intervalo interquartílico (IIQ: Q1-Q3) e comparados pelo teste dos postos sinalizados de Wilcoxon e os dados categóricos foram expressos pela frequência e porcentagem e comparados pelo teste de McNemar corrigido.

Observou-se que existe variação estatisticamente significativa do pré para pós-intervenção em todos os parâmetros dos questionários, ou seja, houve queda significativa na pontuação da Escala Visual Analógica de Dor, aumento significativo nas pontuações do Questionário de Lysholm e da Escala de Atividades de Vida Diária em ambos os grupos ( $p \leq 0,001$, para todos) (Tabela 6). 
A tabela 7 fornece a descritiva dos parâmetros dos questionários segundo o grupo (intervenção e controle) e o correspondente nível descritivo ( $p$ valor) do teste estatístico. Os deltas dos parâmetros dos questionários foram calculados a partir das diferenças absolutas entre os momentos pré e pós-intervenção (pós-pré).

Tabela 7. Comparação entre os momentos pré e pós-intervenção entre os grupos para os parâmetros subjetivos - Escala Visual Analógica de dor (EVA), Questionário de Lysholm e Escala de Atividades de Vida Diária (EAVD). Brasília, 2019
Parâmetros
G. Intervenção
G. Controle
p valor

Momento

pré-intervenção

EVA (pontos)

$0,5 \quad 0,0-1,0$

1,0

$0,0-1,9$

0,41

Questionário

de 85,0

$81,5-90,0$

90,0

$85,0-90,0$

0,11

Lysholm

$\begin{array}{llllllll}\text { EAVD: Nota (pontos) } \quad 90,0 & 85,0 & -95,0 & 90,0 & 86,3 & -95,0 & 0,42\end{array}$

EAVD: Nível

Funcional

Normal

$12(27,3 \%)$

$10(22,7 \%)$

0,62

Quase normal

$32(72,7 \%)$

$34(77,3 \%)$

EAVD: Nível de

Atividade

Normal

$14(31,8 \%)$

$15(34,1 \%)$

0,82 


\section{Momento \\ pós-intervenção}

EVA (pontos)

$0,0 \quad 0,0-0,5$

0,50

$0,0-1,0$

0,005

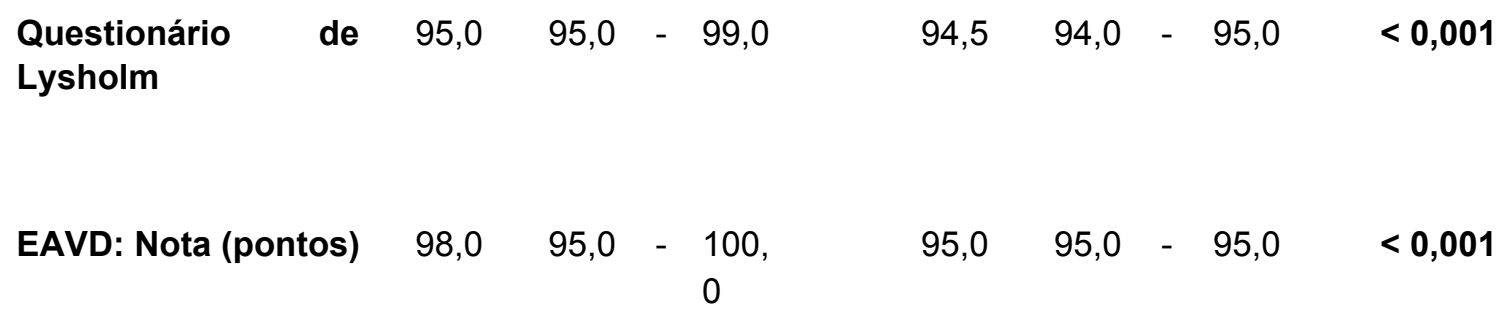

EAVD: Nível

Funcional
Normal
$42(95,5 \%)$
$42(95,5 \%)$
1,0
Quase normal
$2(4,5 \%)$
$2(4,5 \%)$

EAVD: Nível de
Atividade
Normal
$41(93,2 \%)$
$41(93,2 \%)$
1,0
Quase normal
$3(6,8 \%)$
$3(6,8 \%)$

\section{Delta (pós-pré)}




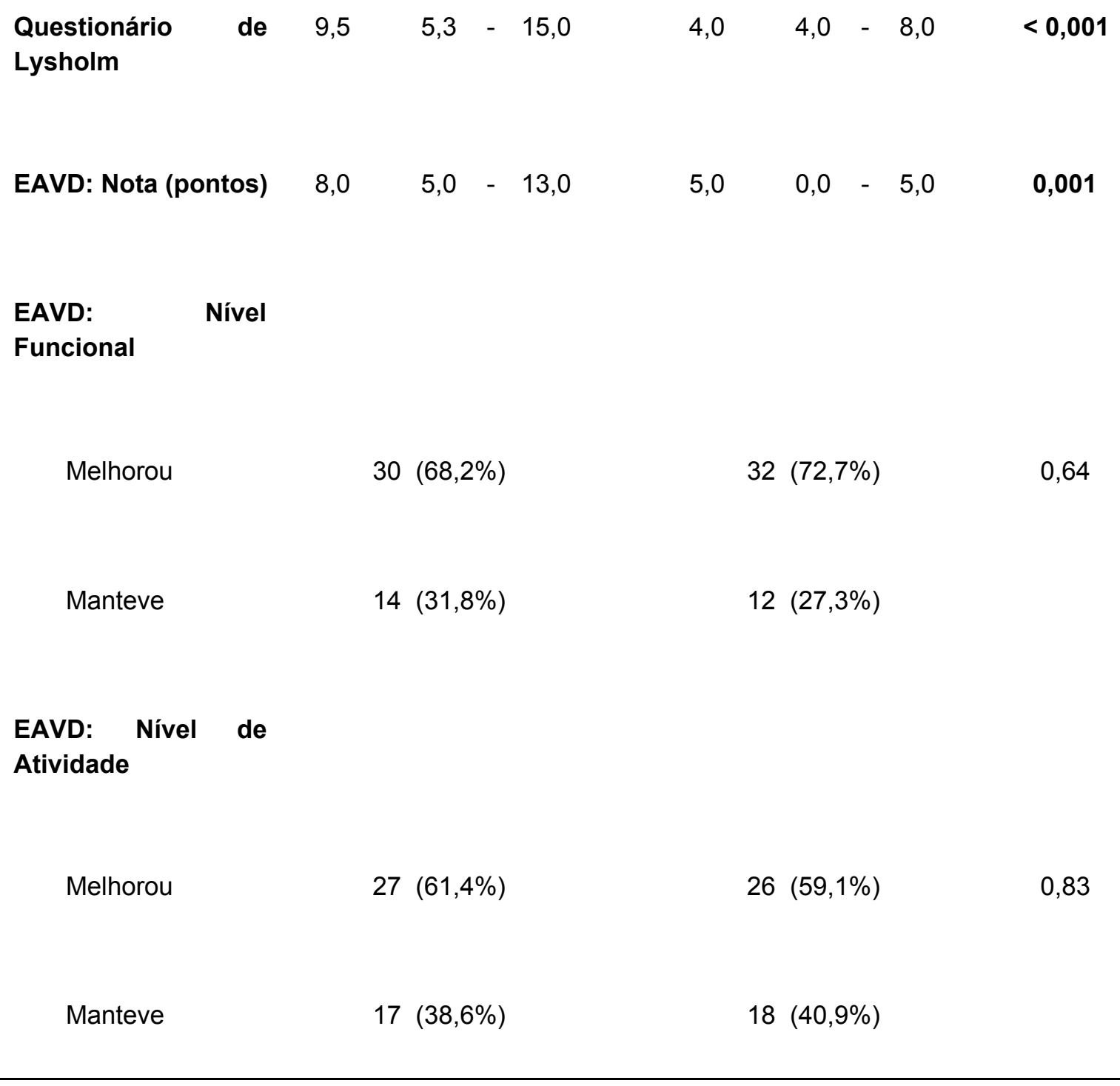

Os dados numéricos foram expressos pela mediana e intervalo interquartílico (IIQ: Q1-Q3) e comparados pelo teste de Mann-Whitney e os dados categóricos foram expressos pela frequência e porcentagem e comparados pelo teste de $X^{2}$ ou exato de Fisher.

Observou-se que no momento pré-intervenção não existia diferença estatisticamente significante nos parâmetros dos questionários entre os dois grupos. No momento pós-intervenção, o grupo intervenção apresentou pontuação na Escala Visual Analógica de Dor significativamente menor e as pontuações no Questionário de Lysholm e na Escala de Atividades de Vida Diária significativamente maiores que o grupo controle; os grupos evoluíram de forma diferenciada nas pontuações do Questionário de Lysholm e na Escala de Atividades de Vida Diária, ou seja, o delta (aumento) das pontuações foi significativamente maior no Gl que no GC (Tabela 7).

A tabela 8 fornece a descritiva dos parâmetros de força no membro doador (MD) e membro receptor (MR) e o correspondente nível descritivo ( $p$ valor) do teste 
estatístico no interior de cada grupo. Os parâmetros de força foram calculados a partir das diferenças absolutas entre os momentos pré e pós (pós-pré), isto é, correspondem a variação absoluta após intervenção. Observou-se, no grupo intervenção, que existe variação (redução) significativa em todos os parâmetros de força do membro doador para receptor, ou seja, há um aumento da simetria entre os membros após a intervenção; já no grupo controle, existe variação (aumento) estatisticamente significativo em todos os parâmetros de força do membro doador para receptor, ou seja, há uma perda da simetria entre os membros.

Tabela 8. Parâmetros de força nos membros doador e receptor no interior do grupo. Brasília, 2019

\begin{tabular}{|c|c|c|c|c|c|c|c|c|}
\hline \multirow{3}{*}{$\begin{array}{l}\begin{array}{c}\text { Força do } \\
\text { parâmetro }\end{array} \\
\text { Grupo Intervenção }\end{array}$} & \multicolumn{3}{|c|}{ Membro Doador } & \multicolumn{4}{|c|}{ Membro Receptor } & \multirow[t]{3}{*}{$p$ valor } \\
\hline & $\begin{array}{c}\text { median } \\
a\end{array}$ & \multicolumn{2}{|r|}{$\| \mathrm{Q}$} & $\begin{array}{l}\text { median } \\
\quad \mathrm{a}\end{array}$ & \multicolumn{3}{|c|}{ IIQ } & \\
\hline & & & & & & & & \\
\hline Perimetria a $10 \mathrm{~cm}$ & 2,00 & 1,50 & - 2,88 & 0,50 & 0,30 & - & 1,00 & $<0,001$ \\
\hline Perimetria a $20 \mathrm{~cm}$ & 2,00 & 1,25 & - 2,88 & 0,50 & 0,00 & - & 0,85 & $<0,001$ \\
\hline Perimetria a $30 \mathrm{~cm}$ & 2,00 & 1,50 & $-\quad 2,98$ & 0,50 & 0,25 & - & 1,00 & $<0,001$ \\
\hline $\begin{array}{l}\text { Pico de torque de } \\
\text { extensão }\end{array}$ & 19,6 & 14,7 & $-24,8$ & 5,00 & 2,85 & - & 6,28 & $<0,001$ \\
\hline
\end{tabular}

\section{Grupo Controle}

$\begin{array}{llllllll}\text { Perimetria a } 10 \mathrm{~cm} & 1,00 & 0,50 & - & 1,00 & 2,00 & 1,50 & -\end{array}$




$\begin{array}{lrrrrrrrr}\text { Perimetria a 20cm } & 1,00 & 1,00-1,33 & 2,50 & 1,85-2,50 & <\mathbf{0 , 0 0 1} \\ \text { Perimetria a 30cm } & 1,00 & 0,50-1,50 & 2,00 & 1,28-2,50 & <\mathbf{0 , 0 0 1} \\ \begin{array}{l}\text { Pico de torque de } \\ \text { extensão }\end{array} & 9,40 & 7,15-11,0 & 17,0 & 13,6-22,0 & <\mathbf{0 , 0 0 1} \\ \end{array}$

Os dados numéricos foram expressos pela mediana e intervalo interquartílico (IIQ: Q1-Q3) e comparados pelo teste dos postos sinalizados de Wilcoxon. Força corresponde a variação do pré para pós-intervenção: pós-pré.

A tabela 9 fornece a descritiva dos parâmetros de força segundo o grupo (intervenção e controle) e o correspondente nível descritivo ( $p$ valor) do teste estatístico. Os deltas dos parâmetros de força foram calculados a partir das diferenças absolutas entre os membros doador e receptor (MR-MD).

Observou-se que no membro doador (MD), existe diferença estatisticamente significante nos parâmetros de força entre os dois grupos, ou seja, o grupo intervenção apresentou parâmetros de força significativamente maiores que o grupo controle.

No membro receptor (MR), existe diferença estatisticamente significante nos parâmetros de força entre os dois grupos, ou seja, o grupo intervenção apresentou parâmetros de força significativamente menor que o grupo controle; e os grupos evoluem de forma diferenciada no delta da força da perimetria e do pico de torque (Tabela 9).

Tabela 9. Parâmetros de força segundo o grupo. Brasília, 2019

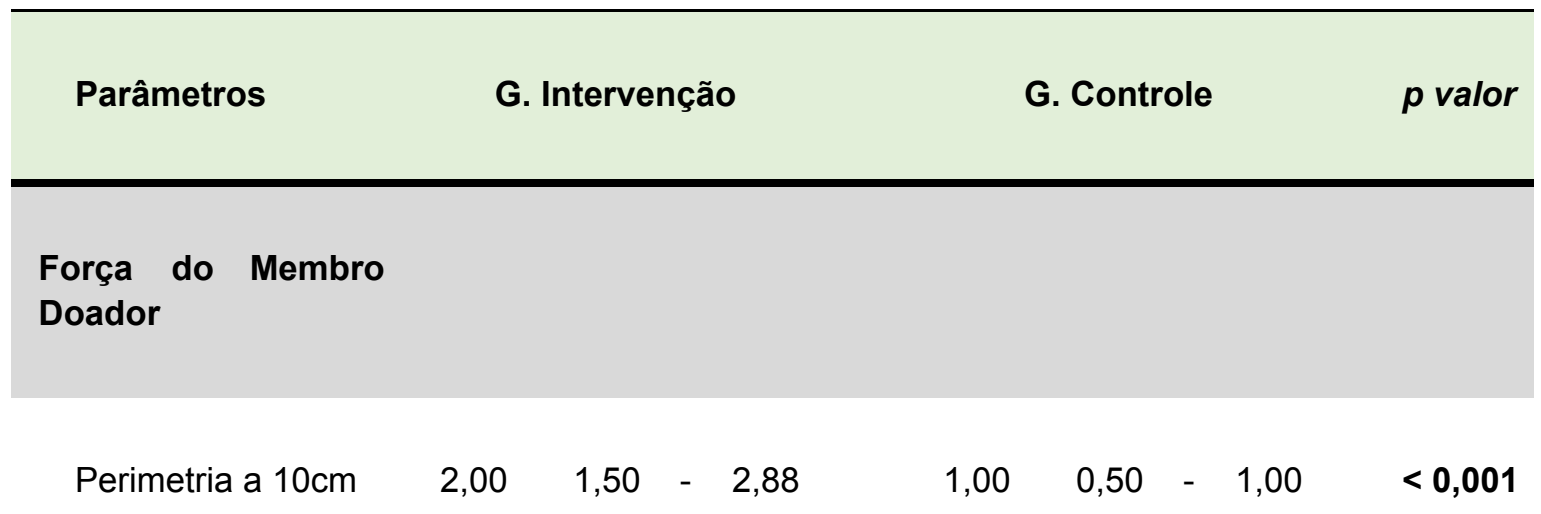




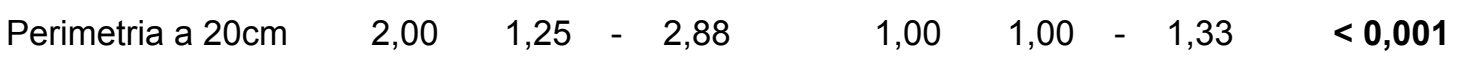

$\begin{array}{lllllllll}\text { Perimetria a } 30 \mathrm{~cm} & 2,00 & 1,50 & - & 2,98 & 1,00 & 0,50 & - & 1,50\end{array}$

Pico de torque de 19,6 14,7 - 24,8 $\quad 9,4 \quad 7,2 \quad-\quad 11,0 \quad<0,001$ extensão

\section{Força do Membro \\ Receptor}

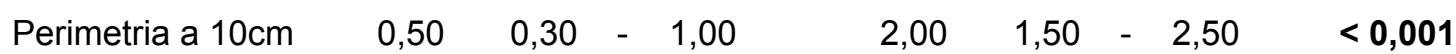

$\begin{array}{lllllllll}\text { Perimetria a } 20 \mathrm{~cm} & 0,50 & 0,00 & - & 0,85 & 2,50 & 1,85 & - & 2,50\end{array} \quad \mathbf{0 , 0 0 1}$

$\begin{array}{llllllll}\text { Perimetria a } 30 \mathrm{~cm} & 0,50 & 0,25 & - & 1,00 & 2,00 & 1,28 & -\end{array}$

Pico de torque de $5,00 \quad 2,85 \quad-\quad 6,28 \quad 17,0 \quad 13,6 \quad-22,0 \quad<0,001$ extensão

\section{Delta da Força}

$\begin{array}{lrrrrrrr}\text { Perimetria a } 10 \mathrm{~cm} & -1,50 & -2,0 & - & -1,0 \\ 0 & 0\end{array} \quad 1,00 \quad 0,50 \quad-\quad 1,50 \quad<0,001$

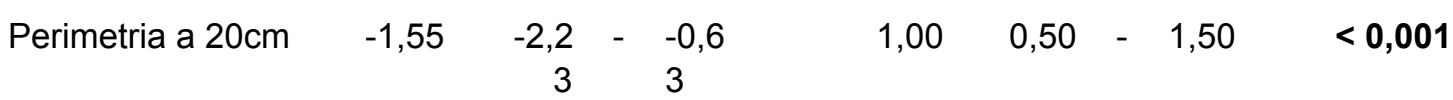

$\begin{array}{llllllllll}\text { Perimetria a } 30 \mathrm{~cm} & -1,50 & -2,0 & - & -0,5 & 1,00 & 0,50 & - & 1,50 & <0,001\end{array}$ 
Pico de torque de $-13,9 \quad-20, \quad-\quad-9,8$ extensão

Os dados numéricos foram expressos pela mediana e intervalo interquartílico (IIQ: Q1-Q3) e comparados pelo teste de Mann-Whitney. Força corresponde a variação do pré para pós-intervenção: pós-pré. Delta da força corresponde a variação do membro doador para o receptor.

Entre os critérios de avaliação sensório-motora, observou-se que todos(as) os(as) participantes da pesquisa encontravam-se dentro do padrão de normalidade no teste de ativação do quadríceps.

A análise final da amostra (após o período de intervenção) para os parâmetros objetivos de avaliação, considerando os critérios de retorno ao esporte indicados pela literatura, demonstrou que o Grupo Intervenção se encontrava em condições de alta para todas as variáveis (Tabela 10).

Tabela 10. Valores médios e classificação final da amostra para as variáveis quantitativas - Grupo Intervenção. Brasília, 2019

\begin{tabular}{|c|c|c|c|c|}
\hline Variáveis & $\begin{array}{c}\text { Membro } \\
\text { doador }\end{array}$ & $\begin{array}{l}\text { Membro } \\
\text { receptor }\end{array}$ & Referência & Classificação \\
\hline \multirow[t]{2}{*}{ ADM de hiperextensão } & 7,0 & 6,0 & IKDC (2000) & Normal \\
\hline & 146,0 & 146,0 & IKDC (2000) & Normal \\
\hline \multirow[t]{2}{*}{ Perimetria ao nível da LA } & 36,0 & 36,0 & $\begin{array}{l}\text { Malone et al. } \\
\quad(2000)\end{array}$ & Normal \\
\hline & & & Magee (2005) & \\
\hline Perimetria a $10 \mathrm{~cm}$ & 43,0 & 43,0 & $\begin{array}{l}\text { Malone et al. } \\
(2000)\end{array}$ & Normal \\
\hline
\end{tabular}


Perimetria a $20 \mathrm{~cm}$

Perimetria a $30 \mathrm{~cm}$

59,0

59,0

120,0

116,0

Y Balance Test - Anterior

Y Balance Test - Medial

Y Balance Test - Lateral

KT-1000 ${ }^{\mathrm{TM}}$

Relação I/Q

Pico de torque de extensão
70,0

Plisky et al. (2006)

70,0

94,0

103,0

104,0

Plisky et al. (2006)

5,0

59,0

53,0

174,0

184,0
Grindem et al.

(2016)

$\operatorname{IKDC}(2000)$

Normal
Grindem et al. (2016)

Normal

Normal

Normal

Normal

Normal

Normal

Normal

Normal

Normal

No Grupo Controle, foram encontradas alterações nos parâmetros de perimetria a 10, 20 e 30cm acima da linha articular, relação I/Q e pico de torque de extensão, demonstrando a presença de assimetria significativa entre os membros doador e receptor. Neste grupo, portanto, o retorno ao esporte estaria contraindicado com base nos critérios indicados pela literatura. 
Tabela 11. Valores médios e classificação final da amostra para as variáveis quantitativas - Grupo Controle. Brasília, 2019

\begin{tabular}{|c|c|c|c|c|}
\hline Variáveis & $\begin{array}{l}\text { Membro } \\
\text { doador }\end{array}$ & $\begin{array}{l}\text { Membro } \\
\text { receptor }\end{array}$ & Referência & Classificação \\
\hline ADM de hiperextensão & 6,0 & 6,0 & IKDC (2000) & Normal \\
\hline ADM de flexão & 147,0 & 146,0 & IKDC (2000) & Normal \\
\hline \multirow[t]{2}{*}{ Perimetria ao nível da LA } & 37,0 & 38,0 & $\begin{array}{l}\text { Malone et al. } \\
\quad(2000)\end{array}$ & Normal \\
\hline & & & Magee (2005) & \\
\hline \multirow[t]{2}{*}{ Perimetria a $10 \mathrm{~cm}$} & 44,0 & 47,0 & $\begin{array}{l}\text { Malone et al. } \\
\quad(2000)\end{array}$ & Alterada* \\
\hline & & & Magee (2005) & \\
\hline \multirow[t]{2}{*}{ Perimetria a $20 \mathrm{~cm}$} & 52,0 & 55,0 & $\begin{array}{l}\text { Malone et al. } \\
\quad(2000)\end{array}$ & Alterada* \\
\hline & & & Magee (2005) & \\
\hline \multirow[t]{2}{*}{ Perimetria a $30 \mathrm{~cm}$} & 58,0 & 60,0 & $\begin{array}{l}\text { Malone et al. } \\
\quad(2000)\end{array}$ & Alterada* \\
\hline & & & Magee (2005) & \\
\hline Single Leg Hop Test & 122,0 & 129,0 & IKDC (2000) & Normal \\
\hline Y Balance Test - Anterior & 68,0 & 74,0 & Plisky et al. (2006) & Normal \\
\hline
\end{tabular}


Y Balance Test - Medial

89,0

$$
96,0
$$

Plisky et al. (2006)

Normal

Y Balance Test - Lateral

100,0

109,0

Plisky et al. (2006)

Normal

KT-1000 ${ }^{\mathrm{TM}}$

4,0

5,0

IKDC (2000)

Relação I/Q

64,0

51,0

Grindem et al.

(2016)

199,0

Grindem et al.

(2016)

Pico de torque de extensão

\section{Normal \\ Normal}

*A comparação entre os membros está fora dos padrões de normalidade.

\section{DISCUSSÃO}

No presente estudo foram acompanhados 88 pacientes submetidos a RLCA com utilização do enxerto contralateral. Além da faixa etária mais prevalente de lesões dessa natureza (Larson, 1994), prática de esportes mesmo em nível recreacional (Bonfim e Paccola, 2000; Maxey e Magnusson, 2003), características antropométricas e demográficas semelhantes entre os grupos de pesquisa, o que favoreceu a análise de dados e diminuiu os vieses de aferição e seleção. Apenas o pesquisador foi responsável pelos protocolos de intervenção e as avaliações foram cegadas. Foram realizados pré-testes e os equipamentos foram calibrados. Todos os pacientes foram esclarecidos sobre os aspectos da pesquisa.

O gênero predominante na amostra foi o masculino (67\%), o que pode ser explicado pela maior presença dos homens nas práticas esportivas como um todo, o que os levam a ficar mais expostos. Porém, em esportes em que temos uma igualdade de participação entre gêneros, a probabilidade de uma lesão do LCA ocorrer em mulheres pode ser de 2-8 vezes maior do que em homens (Larson, 1994; Montgomery e Miller, 2005).

Embora não encontrados estudos que correlacionam a dominância do indivíduo com a lesão do LCA, a grande maioria dos indivíduos em nossa amostra eram destros.

Os nossos resultados demonstraram que ambos os grupos submetidos a intervenção obtiveram evolução, porém há uma predominância do grupo intervenção (unilateral) em relação ao grupo controle(bilateral). 
Após acompanhamento de 831 pacientes, nos quais 434 utilizaram o enxerto contralateral, 228 utilizaram o enxerto ipsilateral e os demais outras técnicas, Shelbourne e Urch (2000) concluíram que a técnica contralateral se trata de um método seguro, rápido e simples, sendo este livre de complicações.

Jari e Shelbourne (2002) em seu estudo de caso, descreveram a recuperação da força após a RLCA contralateral, de forma rápida e satisfatória, do ponto de vista do desempenho muscular, amplitude de movimento e funcionalidade em ambos os membros até $012^{\circ}$ mês pós-operatório. Nessa perspectiva não houveram novos estudos comparando a evolução com o ganho de força.

No Brasil, os primeiros trabalhos relacionados a RLCA com o enxerto contralateral foram feitos por Oliveira et al (2006) e Lobo et al (2006). Oliveira apresentou resultados a curto prazo de uma atleta de vôlei profissional, que na terceira semana de pós operatório apresentava ADM completa de flexão, hiperextensão e independência funcional em suas AVD's. Já o trabalho de Lobo, em uma pesquisa de maior abrangência, os resultados de 256 pacientes com 2 anos de acompanhamento pós-cirúrgico foram apresentados, avaliados e classificados em condições adequadas em relação a estabilidade ligamentar objetiva (KT-1000), amplitude de movimento (goniometria), trofismo (perimetria), nível de satisfação e tempo de retorno às atividades (registradas em prontuários). Apesar dos pacientes serem descritos com parâmetros suficientes para alta do tratamento, o desempenho muscular não foi verificado.

Posteriormente Leal et al. (2011) avaliou transversalmente 22 indivíduos que haviam sido submetidos à RLCA com enxerto contralateral e a um programa comum de reabilitação no período de 3 a 10 anos após o procedimento. Em seus resultados encontraram uma considerável assimetria entre os membros doador e receptor para 0 Single Leg Hop Test, relação I/Q e pico de torque de extensão à $60 \%$ s e $180 \%$ s.

Ainda no Brasil, Oliveira et al. (2014) realizou um trabalho semelhante, entretanto avaliou os pacientes a curto prazo, no momento de alta, e em média 5 meses após a intervenção cirúrgica. Os resultados demonstraram que os pacientes estavam recuperados do ponto de vista funcional, mas a avaliação isocinética apresentou significativos níveis de assimetria no desempenho muscular entre os membros, no qual o doador se mostrou deficitário.

Xergia et al (2011), em sua revisão sistemática concluiu que aparentemente há uma tendência a fraqueza muscular do local doador do enxerto após a RLCA em pacientes que optaram pelo enxerto autógeno patelar quando comparados com pacientes que utilizaram-se do enxerto autógeno dos isquiotibiais.

Apesar da relevância do tema, poucos trabalhos estudaram uma estratégia de progressão dos exercícios resistidos na fase pós-operatória do LCA, principalmente no tocante a melhora do desempenho muscular e obtenção da simetria entre os membros. Até o presente momento a literatura acerca do tema tem se limitado a entender o momento exato para introduzir o exercício resistido (Triston e Marie, 2005; Gerber et al.., 2009; Kristensen e Franklyn-Miller, 2012), às cargas geradas durante os exercícios, e principalmente a comparação entre CCA e CCF (Escamilla et al., 2012; Perriman et al., 2018), além dos efeitos e progressão dos exercícios sensório-motores (treinamento neuromuscular) (Risberg et al., 2007). Outros estudos têm estudado em variáveis 
indiretas, como os benefícios da realização de exercícios para o tronco na reabilitação do LCA (Priyanka et al., 2017).

Em um estudo clínico randomizado cego, com 91 pacientes (48 realizaram exercícios e 55 foram mantidos como controle), Triston e Marie (2005) objetivaram avaliar a efetividade de exercícios para o quadríceps na fase inicial (duas semanas após intervenção cirúrgica) da reabilitação após RLCA (utilizando enxertos do ligamento da patela e isquiotibiais), avaliando os pacientes no primeiro dia, duas semanas, três e seis meses após o procedimento. Foram prescritos exercícios de elevação do membro estendido e contrações isométricas do quadríceps. Concluíram através de seus resultados que os exercícios prescritos não geram complicações e contribuem para a recuperação mais rápida da amplitude de movimento (primeiro mês) e estabilidade articular, apesar de no final do tratamento não terem observado diferenças significativas no desempenho muscular e capacidade sensório-motora entre os grupos.

Em seu estudo randomizado cego, com 74 pacientes submetidos a RLCA, Risberg et al., (2007) objetivou determinar o efeito de um programa de treinamento neuromuscular de 6 meses em comparação a um programa tradicional de exercícios resistidos. Os grupos foram avaliados no período pré-operatório, $3^{\circ}$ e $6^{\circ}$ mês pós-operatório. Os resultados do estudo não demonstram diferenças entre os grupos no tocante a testes funcionais e avaliação da força muscular, porém o grupo submetido ao tratamento neuromuscular apresentou uma pontuação significativamente maior nos escores subjetivos - Cincinnati e EVA. A conclusão sugere que a inclusão de exercícios sensório-motores deve fazer parte do programa de reabilitação após a reconstrução do LCA.

Gerber et al. (2009) avaliou os efeitos da implementação de um programa de exercícios excêntricos progressivos associados à reabilitação convencional no volume muscular e funcionalidade um ano após a RLCA. Por meio de um estudo clínico randomizado, acompanhou 40 pacientes divididos em dois grupos com 0 mesmo número de pacientes. O primeiro grupo realizou o programa por 12 semanas desde o início da reabilitação. Os demais foram mantidos sob a reabilitação padrão. Como critérios de avaliação, foram realizadas a avaliação clínica do joelho, testes funcionais, avaliação de força, aplicação de questionários e exames de ressonância magnética das coxas. Os resultados demonstraram que o grupo submetido ao programa de exercícios excêntricos associados à reabilitação convencional apresentou melhores resultados (melhora maior que $50 \%$ ) que o grupo controle, o que pode vir a ser uma tendência a ser seguida para tomada de decisão clínica na hora da periodização de treino para pacientes com perfis semelhantes.

Em um resumo das evidências relacionadas a prescrição de exercícios resistidos após a RLCA, Escamilla et al., (2012) teve como seu principal questionamento as forças de tensão sobre o enxerto durante a realização em CCA e CCF. A literatura demonstra que existe maior sobrecarga em CCA, sendo esta acentuada nos ângulos de $10^{\circ}$ a $50^{\circ}$ de flexão, com o pico entre $10^{\circ}$ a $30^{\circ}$. Entretanto em CCF a maior sobrecarga sobre o enxerto ocorre entre $50^{\circ}$ a $100^{\circ}$ de flexão. Há estratégias de variações que visam diminuir essa sobrecarga no enxerto, entre estas estão principalmente a inclinação do tronco à frente (agachamento convencional ou afundo), podendo ser o motivo dessa diminuição a maior ativação dos isquiossurais. 
Perriman et al., (2018) em sua revisão sistemática e metanálise objetivou determinar se exercícios em CCA resultam em diferenças na translação tibial anterior, força muscular, qualidade de vida, função e possíveis complicações associadas à conduta quando comparada ao uso do exercício em CCF no pós-operatório do LCA. Seus resultados demonstraram baixa a moderada qualidade da evidência sobre a ausência de diferença entre os procedimentos para os critérios avaliados, exceto para a funcionalidade, que não foi passível de análise. Ao final, concluiu afirmando que o enxerto de flexores pode ser mais vulnerável que o ligamento da patela, mas esse dado demonstra limitado nível de evidência, e recomenda cautela na introdução de exercícios em CCA nas 12 primeiras semanas após a intervenção cirúrgica.

Em relação a outros exercícios que podem favorecer a recuperação dos pacientes, Priyanka et al. (2017) avaliaram os efeitos de um programa de estabilização do tronco sobre a dor, amplitude de movimento e função após a RLCA. Em seu estudo, submeteu 60 pacientes de forma randomizada a grupos intervenção (tratamento convencional somado a exercícios de fortalecimento do tronco) e controle (somente o tratamento convencional). Concluíram que a introdução de exercícios para estabilização do tronco não influenciou diretamente na dor e ADM, porém promoveu a melhora significativa na funcionalidade dos pacientes. Wu et al. (2017), com objetivo de avaliar os efeitos do fortalecimento dos músculos do CORE na função do joelho e estabilidade postural após a RLCA, submeteu 80 pacientes alocados de forma randomizada em grupos intervenção $(n=40)$ e controle $(n=40)$, a um período de 24 meses de acompanhamento, onde no primeiro foram introduzidos exercícios de fortalecimento do CORE (core training) e no segundo foi mantida a reabilitação convencional. Ao final do período, quando comparados os grupos quanto à pontuação no Questionário de Lysholm, estabilidade articular objetiva (KT-1000 ${ }^{m}$ e resultado do Star Excursion Balance Test, observou uma melhora significativa no grupo intervenção. Concluiu que a introdução do core training pode melhorar o equilíbrio dinâmico em pacientes submetidos à RLCA.

Os resultados do nosso estudo corroboram a literatura atual, pois o programa de reabilitação adotado para os nossos pacientes foi baseado em condutas atuais, efetivas e eficientes. Os exercícios resistidos e sensório-motores foram iniciados o mais breve possível e seguiram uma progressão sistemática e lógica, respeitando a evolução dos sintomas e incluindo os exercícios de estabilização do tronco. Os músculos do MMII foram trabalhados em CCF e CCA, utilizando-se das fases concêntrica e excêntrica e respeitando os ângulos de proteção do enxerto. Entretanto consideramos que o fator preponderante, foi favorecer o membro doador, cuja deficiência muscular foi constatada nas pesquisas anteriores e evidente nos nossos resultados da avaliação pré-intervenção.

A diminuição do desempenho muscular do quadríceps após a RLCA pode ser explicada pelos seguintes fatores: a natureza do procedimento cirúrgico, que utiliza como enxerto para reconstrução do LCA rompido, o ligamento da patela, o meio de fixação do quadriceps na tíbia (Yasuda et al., 1992); o desuso muscular seguido da intervenção cirúrgica (Wilk et al., 1994); perda da massa muscular (hipotrofia) com diminuição da área de secção transversa secundária ao descondicionamento (Kandarian, 2002); hipotrofia seletiva das fibras do tipo II de contração rápida (Martin, 1990); perda do controle neuromuscular devido dor anterior do joelho (Kvist, 2004); inibição reflexa muscular iatrogênica devido ao inchaço articular pós-operatório (Snydler-Mackler et al., 1994); reabilitação tardia em CCA (Higuchi, 2002) por receio de evitar sobrecarga no enxerto em cicatrização ou patelofemoral (Steinkamp et al., 
1993). Como não há alteração no mecanismo flexor, este não é significativamente afetado nesse tipo de paciente (Yasuda et al., 1992; Hiemstra et al., 2000; Lautamies et al., 2008 e Xergia et al., 2011).

A predominância do grupo intervenção (ganho de força e melhora da simetria) usando o exercício unilateral em relação ao grupo controle ou bilateral, como observada em nosso estudo, pode ser explicada de diversas formas a partir da análise de trabalhos que fizeram comparações semelhantes.

Gonzalo-Skok et al. (2016) realizou um estudo com vinte e dois jogadores de basquete divididos aleatoriamente para a realização de treinamento unilateral $(n=$ 11 / média de idade $16.8 \pm 1.7$ anos) ou bilateral $(n=11 /$ média de idade $16.7 \pm 1.7$ anos) durante um período de 6 semanas. Ambos os grupos realizaram 3 séries agachamento até $90^{\circ}, 2$ séries de 5 saltos verticais (drop jumps) e 2 conjuntos de 5 saltos com contra movimento, unilaterais ou bilaterais. Como resultado verificou-se que ambos os programas melhoraram os testes de aptidão física, porém apenas o grupo unilateral reduziu a assimetria entre os membros e demonstrou melhores resultados nas ações que requerem aplicação de força unilateral.

No mesmo sentido Núnez et al., (2018) verificou em seu estudo que o treinamento de força unilateral parece ser mais eficaz na melhora do desempenho e nas habilidades de trocas de direções do que o modo bilateral.

Ao comparar as adaptações neuromusculares dos treinamentos unilateral e bilateral para os músculos extensores do joelho, Botton et al., (2016) submeteu 43 mulheres jovens praticantes de esportes em nível recreacional a um programa de 12 semanas de exercícios resistidos duas vezes por semana. Os indivíduos foram avaliados antes e após a intervenção no que diz respeito à força máxima de extensão do joelho (teste de 1RM), força isométrica à dinamometria isocinética, atividade eletromiográfica e a espessura muscular através da ultrassonografia. Os grupos obtiveram aumentos semelhantes nos testes de 1RM e espessura muscular. O teste isométrico demonstrou um melhora significativa para o grupo unilateral quando comparado ao bilateral $(21,4 \pm 10.5 \%$ contra $10.3 \pm 11.1 \%)$, o que também pode ser visto na atividade elétrica, destacando que para esta última apenas o grupo unilateral obteve aumento dos valores. Como os seus resultados pode-se concluir que se o objetivo do treinamento for maximizar o ganho de força de cada membro isoladamente, o treinamento unilateral deverá ser recomendado, o que não deve ser considerado se o objetivo do treinamento for promover adaptações neuromusculares na amostra.

Segundo Owings e Grabiner (1998), a diferença entre a produção de força máxima durante ações bilaterais quando comparadas às ações unilaterais, é denominada déficit bilateral (DB). Trata-se de um fenômeno decorrente da redução do desempenho muscular durante movimentos bilaterais (membros sincronizados). As principais hipóteses que justificam o DB estão relacionadas a mecanismos neurais e (ou) mecânicos, como a coativação antagonista, estimulação reduzida de unidades motoras e (ou) fibras do tipo II, o recrutamento neural diferenciado pelo efeito cruzado no trato extrapiramidal, diferenças de fibras nos membros e a predominância de utilização de um membro em detrimento do outro, resultando em menor produção de força (Botton, Pinto, 2012).

Em nosso trabalho, partindo do ponto em que já existia uma discrepância no desempenho muscular dos membros inferiores dos pacientes e foi acentuada no GC, tornou-se plausível que o exercício resistido de modo bilateral acentuou o DB pelo uso do membro receptor, cuja deficiência é significativamente menor que a do membro doador. Considerando o resultado contrário encontrada no grupo 
intervenção, que isolou o membro doador e, assim atingiu níveis significativamente maiores de simetria, nos leva a crer que a hipótese do estudo seja real.

A análise da condição final dos pacientes também demonstrou alterações na relação muscular entre quadríceps e isquiotibiais (I/Q). Esta vem sendo analisada para assegurar a habilidade funcional do joelho e seu equilíbrio muscular em ambos os gêneros, diferentes idades e em programas de reabilitação (Rosene et al., 2001).É convencionalmente calculada como a maior força encontrada de flexão de joelho dividida pela força máxima de extensão do joelho obtida numa determinada velocidade e modo de contração como: isométrico, concêntrico ou excêntrico (Aagaard et al., 1995); Dvir, 2002).

Embora seja difícil generalizar, a relação normal da $\mathrm{H}: \mathrm{Q}$ convencional é considerada entre $50 \%$ a $80 \%$ (Rosene et al., 2001). Sendo que estes valores variam de acordo com a velocidade angular, assim ela assume valores de $50-60 \%$ para baixas velocidades (30\%), 60-70\% para velocidades intermediárias $(120-180 \%$ s) e $70-80 \%$ para velocidades maiores que $180 \%$ s (Pocholle e Codine, 2000). Com o aproximar da relação $H: Q$ aos $100 \%$, os isquiotibiais têm uma capacidade funcional aumentada para fornecer estabilidade ao joelho. Esse aumento da estabilidade do joelho pode reduzir a possibilidade de subluxação ântero-lateral da tíbia dentre outras lesões específicas do joelho e suas consequências (Rosene et al., 2001; Noyes et al., 2005).

Nos pacientes que se encontram no período pós-operatório do ligamento cruzado anterior é comum encontrarmos um aumento dos valores da relação $I / Q$, e esse desequilíbrio pode ser justificado por dois motivos: o aumento da atividade reflexa dos isquiotibiais, decorrente da instabilidade gerada pela perda ligamentar (Wall et al., 1985; Solomonow et al., 1987), e a fraqueza do quadríceps, que é inerente a esse perfil de paciente, seja no período pré ou pós-operatório (Dvir, 2002; Øiestad et al., 2015; Palmieri-Smith e Lepley, 2015). Em nosso trabalho, não há dúvidas de que os resultados podem ser explicados devido a esses motivos.

Atualmente é entendido pelos profissionais e atletas, que a medida do sucesso do tratamento do LCA é o retorno ao esporte no mesmo nível pré-lesão (Ardern et. al 2016a; Ardern et. al, 2016b), o que têm sido relatado entre $26 \%$ e $97 \%$ (Ardern et al., 2014; Waldén et al., 2016; Lai et al., 2018). Considerando os dados alarmantes, encontrar uma maneira mais efetiva de se obter a simetria entre os membros, vem a ser o fator preponderante para um retorno seguro ao esporte, torna-se não apenas relevante, mas uma necessidade para profissionais e pacientes.

Os resultados do presente estudo indicam um novo caminho para a reabilitação dos pacientes submetidos à RLCA contralateral, porém, novas estratégias devem ser desenvolvidas para potencializar os benefícios do exercício unilateral neste grupo. A literatura nos chama atenção acerca de outras alternativas como o exercício isoinercial, o método de oclusão vascular e o aperfeiçoamento dos exercícios sensório-motores. Por último e não menos importante, apesar do tratamento curativo e mesmo após este, é sabido que há de fato um longo caminho a ser percorrido no tocante a prevenção de lesões, complicações a longo prazo, como artrose, e estabelecimento de critérios mais precisos para acompanhamento deste perfil de pacientes. 


\section{CONCLUSÕES}

Com base na avaliação dos resultados obtidos a partir da amostra estudada e comparados com os achados descritos na literatura, pode-se concluir que:

1. A utilização do exercício resistido isotônico unilateral é mais efetiva que a forma bilateral para se obter o maior nível de simetria do desempenho muscular entre os membros doador e receptor na fase pós-operatória do tratamento fisioterapêutico do LCA contralateral;

2. Entre grupos de pesquisa, houve ganho de força em ambos os membros após o período de intervenção, porém esta prevaleceu no membro doador do Grupo Intervenção;

3. Considerando os parâmetros de avaliação e os critérios de alta indicados pela literatura, somente os pacientes do grupo intervenção encontravam-se em condições de alta para o retorno às atividades esportivas;

4. É imprescindível a avaliação e acompanhamento do desempenho muscular nesse tipo de paciente de uma maneira minuciosa e pormenorizada, visto que a avaliação clínica somente como critério de alta pode não ser sensível e (ou) subestimar os déficits e desequilíbrios musculares existentes. 


\section{REFERÊNCIAS BIBLIOGRÁFICAS}

- Aagaard P, Simonsen EB, Trollesgade M, Bangsbo J, Klausen K. Isokinetic hamstring/quadriceps strength ratio: influence from joint angular velocity, gravity correction and contraction mode. Acta Physiol Scand. 1995 Aug;154(4):421-7.

- Amatuzzi MM. Joelho - Joelho Articulação Central dos Membros Inferiores. São Paulo: Roca; 2004. p. 816. ISBN: 9788572414869

- American College of Sports Medicine - ACSM. Guidelines for Exercise Testing and Prescription. 8th Ed. Baltimore: Lippincott Williams \& Wilkins, 2009.

- American College of Sports Medicine - ACSM. Progression models in resistance training for healthy adults. Position Stand. Medicine and Science in Sports and Exercise. 2002; 34:364-80.

- American College of Sports Medicine - ACSM. Quantity and Quality of Exercise for Developing and Maintaining Cardiorespiratory, Musculoskeletal, and Neuromotor Fitness in Aparrently Healthy Adults: Guidance for Prescribing Exercise. Med. Sci. Sports Exerc.2011; 42(7): 1334-59.

- ANDRADE, Marco Antônio Percope de et al. A repercussão da retirada do enxerto do tendão patelar no mecanismo extensor do joelho. Rev. bras. ortop, v. 34, n. 8, p. 461-464, 1999.

- ANDRADE, Marilia Dos Santos et al. Isokinetic hamstrings-to-quadriceps peak torque ratio: The influence of sport modality, gender, and angular velocity. Journal of sports sciences, v. 30, n. 6, p. 547-553, 2012.

- Andrews JR, Harrelson GL, Wilk KE. Reabilitação física das Lesões Desportivas. $2^{\mathrm{a}}$ ed. Rio de Janeiro. Ed. Guanabara Koogan; 2000. ISBN: 9788527705615

- Aquino CF, Vaz DV, Brício RS, Silva PLP, Ocarino JM, Fonseca STA. Utilização da Dinamometria Isocinética nas Ciências do Esporte e Reabilitação. Rev Bras Cie Mov 2008; 15(1): 93-100.

- Ardern CL, Bizzini M, Bahr R. It is time for consensus on return to play after injury: five key questions. $\mathrm{Br} J$ Sports Med. 2016(a) May;50(9):506-8. doi: 10.1136/bjsports-2015-095475. Epub 2015 Nov 20.

- Ardern CL, Kvist J, Webster KE. Psychological Aspects of Anterior Cruciate Ligament Injuries. Operative Techniques in Sports Medicine. 2016(b); 24(1), 77-83.

- Ardern CL, Sonesson S, Forssblad M, Kvist J. Comparison of patient-reported outcomes among those who chose ACL reconstruction or non-surgical treatment. Scand J Med Sci Sports. 2017 May;27(5):535-44.

- Ardern CL, Taylor NF, Feller JA, Webster KE. Fifty-five per cent return to competitive sport following anterior cruciate ligament reconstruction surgery: an updated systematic review and meta-analysis including aspects of physical functioning and contextual factors. Br J Sports Med. 2014 Nov; 48 (21):1543-52. 
- Ataides G, Oliveira M, Lobo Júnior P, Araújo R, Henrique P, Lima R, Damado M. Clinical results and functional surgery the acl reconstruction contralateral in médium term. Universitas: Ciências da Saúde, 2013; v.11, (1):19-28.

- Bernard PL, Edouard P, Tallon G, Perrey S, Billot M, Blain H, Degache F. Influence of recovery time on strength during a testing protocol of knee. Journal de Traumatologie Du Sport, 2016; 33(3):161-166.

- Beynnon BD, Johnson RJ, Fleming BC, Motivational P, Kaplan M, Samani J, Renström $P$. Anterior cruciate ligament replacement: comparison of bone-patellar tendon-bone grafts with two-strand hamstring grafts. A prospective, randomized study. J Bone Joint Surg Am. 2002 Sep;84(9):1503-13.

- BIODEX Medical Systems Inc [internet]. Nova York, 1998. Manual de Aplicações/Operações. Available from: https://www.biodex.com/support/manuals

- Bonfim TR, Paccola CAJ. Propriocepção após a reconstrução do ligamento cruzado anterior usando ligamento patelar homólogo e autólogo. Rev Bras Ortop. 2000; 35(6):194-201.

- Botton CE, Pinto RS. Déficit bilateral: origem, mecanismos e implicações para o treino de força. Rev Bras Cineantropom desempenho hum. 2012: 14(6);749-61.

- BOTTON, Cíntia E. et al. Neuromuscular adaptations to unilateral vs. bilateral strength training in women. Journal of strength and conditioning research, v. 30 , n. 7, p. 1924-1932, 2016.

- Buckthorpe, Matthew \& La Rosa, Giovanni \& Della Villa, Francesco. RESTORING KNEE EXTENSOR STRENGTH AFTER ANTERIOR CRUCIATE LIGAMENT RECONSTRUCTION: A CLINICAL COMMENTARY. International Journal of Sports Physical Therapy. 2019; 14. 159-172. 10.26603/ijspt20190159.

- CARNEIRO FILHO, Mário et al. Reconstruçäo do ligamento cruzado anterior com auto-enxerto de tendäo patelar por via artroscópica. Rev. bras. ortop, v. 34, n. 3, p. 169-78, 1999.

- Carvalho P, Puga N. A avaliação isocinética-joelho. Rev Med Despor. 2010 Jul: 1(4): 26-8.

- Cochran, W.G. Sampling Techniques. 3rd Edition, John Wiley \& Sons, New York. 1977.

- COSTA, Lauro Augusto et al. Analysis of 500 anterior cruciate ligament reconstructions from a private institutional register. PloS one, v. 13, n. 1, 2018.

- Da Silva FC, Deliberato PC. Análise das escalas de dor: Revisão de Literatura Analysis of the Pain Scales: Literature Review. Revista de Atenção à Saúde (antiga Rev. Bras. Ciên. Saúde), 2009, v. 7(19):86-89.

- Dale, M.D., et al. Fate of the ACL-injured patient. A prospective outcome study. Am J Sports Med. 1994; 22: 632-43.

- Daniel DM. Reference, Maintenance \& User's Guide for the Knee Ligament Arthrometer. MEDmetric ${ }^{\circledR}$ Corporation, 1993, v.7542:92121-2412

- Davies GJ, Riemann B, Ellenbecker T. Role of Isokinetic Testing and Training After ACL Injury and Reconstruction. ACL Injuries in the Female Athlete, 2018: 567-588. 
- De Carlo MS, Sell KE. Normative Data for Range of Motion and Single-Leg Hop in High School Athletes. Journal of Sport Rehabilitation, 1997;6(3):246-255.

- Dvir Z, Eger G, Halperin N, Shklar A. Thigh muscle activity and anterior cruciate ligament insufficiency. Clinical Biomechanics, 1989 May;4(2):87-91.

- Ekstrand J. A 94\% return to elite level football after ACL surgery: a proof of possibilities with optimal caretaking or a sign of knee abuse? Knee Surg Sports Traumatol Arthrosc. 2011 Jan;19(1):1-2.

- Escamilla RF, Macleod TD, Wilk KE, Paulos L, Andrews JR. Anterior cruciate ligament strain and tensile forces for weight-bearing and non-weight-bearing exercises: a guide to exercise selection. J Orthop Sports Phys Ther. 2012;42(3):208-20.

- EVANGELIDIS, Pavlos E. et al. Strength and size relationships of the quadriceps and hamstrings with special reference to reciprocal muscle balance. European journal of applied physiology, v. 116, n. 3, p. 593-600, 2016.

- Fleck SJ, Kraemer WJ. Fundamentos do Treinamento de Força Muscular. 3.ed. Porto Alegre, Artmed, 2006.

- Frobell RB, Roos HP, Roos EM, Roemer FW, Ranstam J, Lohmander LS. Treatment for acute anterior cruciate ligament tear: five year outcome of randomised trial. BMJ. 2013 Jan 24;346:f232.

- Gerber JP, Marcus RL, Dibble LE, Greis PE, Burks RT, LaStayo P C. Effects of Early Progressive Eccentric Exercise on Muscle Size and Function After Anterior Cruciate Ligament Reconstruction: A 1-Year Follow-up Study of a Randomized Clinical Trial. Physical Therapy, 2009;89(1), 51-59.

- GONÇALVES, Rui Soles; CABRI, Jan; PINHEIRO, João Páscoa. Cross-cultural adaptation and validation of the Portuguese version of the Knee Outcome Survey-Activities of Daily Living Scale (KOS-ADLS). Clinical rheumatology, v. 27, n. 11, p. 1445-1449, 2008.

- Gonell AC, Romero JA, Soler LM. Relationship between the y balance test scoresand soft tissue injury incidence in a soccer team. Int J Sports Phys Ther. 2015;10(7):955-66.

- Gonzalo-Skok O, Tous-Fajardo J, Arjol-Serrano JL, Suarez-Arrones L, Casajús JA, Mendez-Villanueva A. Improvement of Repeated-Sprint Ability and Horizontal-Jumping Performance in Elite Young Basketball Players With Low-Volume Repeated-Maximal-Power Training. Int J Sports Physiol Perform. 2016 May;11(4):464-73. doi: 10.1123/ijspp.2014-0612. Epub 2015 Sep 10.

- Grindem H, Snyder-Mackler L, Moksnes H, Engebretsen L, Risberg MA. Simple decision rules can reduce reinjury risk by $84 \%$ after $A C L$ reconstruction: the Delaware-Oslo ACL cohort study. Br J Sports Med. 2016 Jul;50(13):804-8.

- Hiemstra LA, Webber S, MacDonald PB, Kriellaars DJ. Knee strength deficits after hamstring tendon and patellar tendon anterior cruciate ligament reconstruction. Med Sci Sports Exerc. 2000;32(8):1472-9.

- Higuchi H, Terauchi M, Kimura M, Shirakura K, Katayama M, Kobayashi F, Takagishi K. Characteristics of anterior tibial translation with active and isokinetic 
knee extension exercise before and after ACL reconstruction. J Orthop Sci. 2002;7(3):341-7.

- Jari S, Shelbourne KD. Staged bilateral anterior cruciate ligament reconstruction with use of contralateral patellar tendon autograft: a case report. Am J Sports Med. 2002;30(3):437-40.

- Kandarian SC1, Stevenson EJ. Molecular events in skeletal muscle during disuse atrophy. Exerc Sport Sci Rev. 2002 Jul;30(3):111-6.

- Karanikas K1, Arampatzis A, Brüggemann GP. Motor task and muscle strength followed different adaptation patterns after anterior cruciate ligament reconstruction. Eur J Phys Rehabil Med. 2009 Mar;45(1):37-45.

- Knudson DV. Aquecimento e flexibilidade. In: Baechle TR, Earle RW. Fundamentos do Treinamento de Força e do Condicionamento. $3^{\mathrm{a}}$ Ed. Barueri: Manole, 2009.

- Kose O, Deniz G, Ozcan H, Guler F. A comparison of telephone interview versus on-site completion of Lysholm knee score in patients who underwent arthroscopic $A C L$ reconstruction: are the results equivalent? Eur J Orthop Surg Traumatol. 2015;25(6):1069-72.

- Kraemer WJ, Fleck SJ. Otimizando o treinamento de força: programas de periodização não-linear. Barueri: Manole, 2009.

- Kristensen J, Franklyn-Miller A. Resistance training in musculoskeletal rehabilitation: a systematic review. Br J Sports Med. 2012;46(10):719-26.

- Kvist J. Rehabilitation following anterior cruciate ligament injury. Sports Med. 2004; 34(4):269-80.

- Larson RL, Taillon M. Anterior Cruciate ligament insufficiency: principles of treatment. J Am Acad Orthop Surg. 1994; 2(1):26-35.

- Laudner K, Evans D, Wong R, Allen A, Kirsch T, Long B, Meister K. Relationship between isokinetic knee strength and jump characteristics following anterior cruciate ligament reconstruction. Int J Sports Phys Ther. 2015 Jun; 10(3): 272-280.

- LAUTAMIES, Riitta et al. Isokinetic quadriceps and hamstring muscle strength and knee function 5 years after anterior cruciate ligament reconstruction: comparison between bone-patellar tendon-bone and hamstring tendon autografts. Knee Surgery, Sports Traumatology, Arthroscopy, v. 16, n. 11, p. 1009-1016, 2008.

- Leal TS, Oliveira MP, Ribeiro MC, Moreira D. Avaliação dos graus de hiperextensão do joelho em praticantes de atividade física. Universitas: Ciências da Saúde, 2011;9,(2):19-34.

- Lepley LK, Palmieri-Smith RM. Pre-operative quadriceps activation is related to post-operative activation, not strength, in patients post-ACL reconstruction. Knee Surg Sports Traumatol Arthrosc. 2016 Jan;24(1):236-46.

- LOBO JUNIOR, Paulo et al. Contralateral patellar tendon autograft in anterior cruciate ligament reconstruction. Acta ortopedica brasileira, v. 26, n. 2, p. 140-144, 2018 
- Lobo P, Lobo R, Neto AR. et al. Resultados clínico/funcionais pós-reconstrução primária do ligamento cruzado anterior com tendão patelar contralateral. Seguimento de 02 anos. In: $11^{\circ}$ CONGRESSO BRASILEIRO DE ARTROSCOPIA E $12^{\circ}$ CONGRESSO BRASILEIRO DE ARTROSCOPIA. 2006, Salvador. Anais.

- Lopes TJA, Simic M, Pappas P. Epidemiology of anterior cruciate ligament reconstruction in brazil's public. Rev Bras Med Esporte, 2016; 22(4):297-301.

- Lutz GE, Stuart MJ, Sim FH, Scott SG. Rehabilitative techniques for athletes after reconstruction of the anterior cruciate ligament. Mayo Clin Proc. 1990;65(10):1322-9.

- Lysholm J, Gillquist J. Evaluation of knee ligament surgery results with special emphasis on use of a scoring scale. Am J Sports Med. 1982;10(3):150-4.

- Machado F, Debieux P, Kaleka CC, Astur D, Peccin MS, Cohen M. Knee isokinetic performance following anterior cruciate ligament reconstruction: patellar tendon versus hamstrings graft. Phys Sportsmed. 2018;46(1):30-35.

- Magee DJ. Avaliação Musculoesquelética. 4.ed. São Paulo, Manole, 2005.

- Mall NA, Chalmers PN, Moric M, et al. Incidence and trends of anterior cruciate ligament reconstruction in the United States. Am J Sports Med. 2014;42(10):2363-2370. doi:10.1177/0363546514542796

- Malone T, Mcpoil T, Nitz AJ. Fisioterapia em ortopedia e medicina no esporte. 1 ed. Brasil: Santos, 2000.

- MARTIN, T. P. et al. Properties of muscle fibers from the vastus lateralis of gluteus medius associated with an osteoarthritic joint. Can J Rehabil, v. 3, p. 151-157, 1990.

- Martinez JE, Grassi DC, Marques LG. Análise da aplicabilidade de três instrumentos de avaliação de dor em distintas unidades de atendimento: ambulatório, enfermaria e urgência. Rev. Bras. Reumatol. 2011;51(4):304-308.

- Maxey L, Magnusson J. Reabilitação pós-cirúrgica para o paciente ortopédico. Rio de Janeiro, Guanabara Koogan, 2003.

- Mcardle WD, Katch FI, Katch VL. Fisiologia do Exercício: Energia, Nutrição e Desempenho Humano. 6a Ed. Rio de Janeiro: Guanabara Koogan, 2008.

- Montgomery SC, Miller MD. What's new in sports medicine. J Bone Joint Surg Am. 2005;87(3):686-94.

- Moses, Bassam \& Orchard, John \& Orchard, Jessica. . Systematic Review: Annual Incidence of ACL Injury and Surgery in Various Populations. Research in sports medicine (Print). 2012; 20. 157-79. 10.1080/15438627.2012.680633.

- Nigri PZ, Peccin MS, Almeida GJ, Cohen M. Tradução, validação e adaptação cultural da escala de atividade de vida diária. Acta ortop. bras. 2007;15(2):101-104.

- Noyes FR, Butler DL, Grood ES, Zernicke RF, Hefzy MS. Biomechanical analysis of human ligament grafts used in knee-ligament repairs and reconstructions. J Bone Joint Surg Am. 1984 Mar;66(3):344-52. 
- NOYES, Frank R. et al. The drop-jump screening test: difference in lower limb control by gender and effect of neuromuscular training in female athletes. The American journal of sports medicine, v. 33, n. 2, p. 197-207, 2005.

- NÚÑEZ, Francisco Javier et al. The effects of unilateral and bilateral eccentric overload training on hypertrophy, muscle power and COD performance, and its determinants, in team sport players. PloS one, v. 13, n. 3, p. e0193841, 2018.

$\bullet$

- ØIESTAD, B. E. et al. Knee extensor muscle weakness is a risk factor for development of knee osteoarthritis. A systematic review and meta-analysis. Osteoarthritis and Cartilage, v. 23, n. 2, p. 171-177, 2015.

- Oliveira MP, Lobo P, Oliveira GA, Moreira D, Machado M, Bessa E, Gertrudes F. Resultados em curto prazo de reabilitação após cirurgia de reconstrução de ligamento cruzado anterior utilizando-se enxerto de tendão patelar contralateral. Universitas: Ciências da Saúde, Brasília, 2014;12(1):29-35.

- Oliveira MP, Lobo P, Oliveira GA, Moreira D, Machado M, Bessa E, Gertrudes F. Resultados em curto prazo de reabilitação após cirurgia de reconstrução de ligamento cruzado anterior utilizando-se enxerto de tendão patelar contralateral. Universitas: Ciências da Saúde, Brasília, 2014;12(1):29-35.

- Oliveira, M; Godoy, JRP; Valduga, R. et al. Programa de reabilitação de ambos os joelhos após a cirurgia primária de reconstrução do LCA utilizando enxerto autógeno de ligamento patelar contralateral. In: $11^{\circ}$ CONGRESSO BRASILEIRO DE ARTROSCOPIA E $12^{\circ}$ CONGRESSO BRASILEIRO DE ARTROSCOPIA. 2006, Salvador. Anais.

- Oliveira, M; Lobo, P; Moreira, D. et al. Desempenho isocinético do joelho após a cirurgia de reconstrução primária do ligamento cruzado anterior utilizando enxerto do tendão patelar contralateral. In: V CONGRESSO DE ORTOPEDIA E TRAUMATOLOGIA DO CENTRO OESTE DO BRASIL. 2009, Brasília. Anais

- OWINGS, Tammy M.; GRABINER, Mark D. Normally aging older adults demonstrate the bilateral deficit during ramp and hold contractions. The Journals of Gerontology Series A: Biological Sciences and Medical Sciences, v. 53, n. 6, p. B425-B429, 1998.

- Palmieri-Smith RM, Lepley LK. Quadriceps Strength Asymmetry After Anterior Cruciate Ligament Reconstruction Alters Knee Joint Biomechanics and Functional Performance at Time of Return to Activity. Am J Sports Med. 2015;43(7):1662-9.

- Patel RR, Hurwitz DE, Bush-Joseph CA, Bach BR Jr, Andriacchi TP. Comparison of clinical and dynamic knee function in patients with anterior cruciate ligament deficiency. Am J Sports Med. 2003 Jan-Feb;31(1):68-74.

- Peccin MS, Ciconelli R, Cohen M. Questionário específico para sintomas do joelho" Lysholm Knee Scoring Scale"-tradução e validação para a língua portuguesa. Acta Ortopédica Brasileira. 2006;14(5):268-272.

- Perriman, Alyssa \& Leahy, Edmund \& Semciw, Adam.. The Effect of Open vs Closed Kinetic Chain Exercises on Anterior Tibial Laxity, Strength, and Function 
Following Anterior Cruciate Ligament Reconstruction: A Systematic Review and Meta-analysis. Journal of Orthopaedic \& Sports Physical Therapy. 2018; 48. 1-52. 10.2519/jospt.2018.7656.

- Pinto SA. Utilização da dinamometria isocinética na reabilitação muscular em pós-cirúrgico de ligamento cruzado anterior. Reabilitar. 2000; 7:11-5.

- Plisky PJ, Rauh MJ, Kaminski TW, Underwood FB. Star excursion balance test as a predictor of lower extremity injury in high school basketball players. J Orthop Sports Phys Ther. 2006;36(12):911-9.

- Pocholle M, Codine P. Les test isocinétiques du genou. Kinésithérapie Scientifique. 2000 Marc; 397:6-13.

- PRIYANKA, Panchal et al. Effects of Lumbar Core Stability Exercise Programme on Knee Pain, Range of Motion, and Function Post Anterior Cruciate Ligament Reconstruction. Journal of Orthopaedics, Trauma and Rehabilitation, v. 23, n. 1, p. 39-44, 2017.

- R. Duchman, Kyle \& Lynch, T. Sean \& Spindler, Kurt.. Graft Selection in Anterior Cruciate Ligament Surgery. Clinics in Sports Medicine. 2016; 36. 10.1016/j.csm.2017.08.013.

- RISBERG, May Arna et al. Neuromuscular training versus strength training during first 6 months after anterior cruciate ligament reconstruction: a randomized clinical trial. Physical therapy, v. 87, n. 6, p. 737-750, 2007.

- Rosene JR, Fogarty TD, Mahaffey BL. Isokinetic hamstrings: quadriceps ratios in intercollegiate athletes. Journal of Athletic Training. 2001;36(4):378-82.

- Rubinstein RA Jr, Shelbourne KD, VanMeter CD, McCarroll JC, Rettig AC. Isolated autogenous bone-patellar tendon-bone graft site morbidity. Am J Sports Med. 1994;22(3):324-7.

- Shaw T, Williams MT, Chipchase LS. Do early quadriceps exercises affect the outcome of ACL reconstruction? A randomised controlled trial. Aust J Physiother. 2005;51(1):9-17.

- Shelbourne KD, Davis TJ. Evaluation of knee stability before and after participation in a functional sports agility program during rehabilitation after anterior cruciate ligament reconstruction. Am J Sports Med. 1999; 27(2)156-61.

- Shelbourne KD, Gray T. Anterior cruciate ligament reconstruction with autogenous patellar tendon graft followed by accelerated rehabilitation. A two-to-nine-year followup. Am J Sports Med. 1997; 256)786-95.

- Shelbourne KD, Klootwyk TE, Wilckens JH, De Carlo MS. Ligament stability two to six years after anterior cruciate ligament reconstruction with autogenous patellar tendon graft and participation in accelerated rehabilitation program. Am J Sports Med. 1995;23(5):575-9.

- Shelbourne KD, Klotz C. What I have learned about the ACL: utilizing a progressive rehabilitation scheme to achieve total knee symmetry after anterior cruciate ligament reconstruction. J Orthop Sci. 2006; 11(3):318-25

- Shelbourne KD, Nitz P. Accelerated rehabilitation after anterior cruciate ligament reconstruction. Am J Sport Med. 1990; 18(3): 292-99. 
- Shelbourne KD, Patel D. Timing of surgery in anterior cruciate ligament $\neg$ injured knees. Knee Surg Sports Traumatol Arthros. 1995; 3(3):148-56.

- Shelbourne KD, Urch S. Primary anterior cruciate ligament reconstruction using the contralateral autogenous patellar tendon graft. Am Journal Sports Med. 2000; 28 (5): 651-58.

- Shelbourne KD, Vanadurongwan B, Gray T. Primary anterior cruciate ligament reconstruction using contralateral patellar tendon autograft. Clin Sports Med. 2007; 26(4):549-65

- Shelbourne, K.D. Mini-open ACL reconstruction using contralateral patellar tendon. Techniques in Orthopaedics. 2005; 20(4):353-60.

- Smith CA, Chimera NJ, Warren M. Association of y balance test reach asymmetry and injury in division I athletes. Med Sci Sports Exerc. 2015;47(1):136-41.

- Snyder-Mackler L, De Luca PF, Williams PR, Eastlack ME, Bartolozzi AR 3rd. Reflex inhibition of the quadriceps femoris muscle after injury or reconstruction of the anterior cruciate ligament. J Bone Joint Surg Am. 1994;76(4):555-60.

- Solomonow M, Baratta R, Zhou BH, Shoji H, Bose W, Beck C, D'Ambrosia R. The synergistic action of the anterior cruciate ligament and thigh muscles in maintaining joint stability. Am J Sports Med. 1987 May-Jun;15(3):207-13.

- Steinkamp LA, Dillingham MF, Markel MD, Hill JA, Kaufman KR. Biomechanical considerations in patellofemoral joint rehabilitation. Am J Sports Med. 1993 May-Jun;21(3):438-44.

- Szczepanik M, Bejer A, Snela S, Szymczyk D, Jabłoński J, Majewska J. Polish Cross-Cultural Adaptation and Validation of the Knee Outcome Survey Activities of Daily Living Scale (KOS-ADLS) in Patients Undergoing Total Knee Arthroplasty. Med Sci Monit. 2018 Jul 31;24:5309-5319. doi: 10.12659/MSM.908094.

- Terreri ASAP, Greve JMD, Amatuzzi MM. Avaliação isocinética no joelho do atleta. Rev Bras Med Esporte. 2001 Set;Out 7(5):170-4.

- Undheim MB, Cosgrave C, King E, Strike S, Marshall B, Falvey É, Franklyn-Miller A. Isokinetic muscle strength and readiness to return to sport following anterior cruciate ligament reconstruction: is there an association? A systematic review and a protocol recommendation. Br J Sports Med. 2015 Oct;49(20):1305-10. doi: 10.1136/bjsports-2014-093962. Epub 2015 Jun 23.

- Vinagre G, Saraiva J. Anterior Cruciate Ligament Reconstruction Graft Options. The Orthopaedic Journal of Sports Medicine. 2018 Jun;6(6)(suppl 3) DOI: $10.1177 / 2325967118500048$.

- Walla DJ, Albright JP, McAuley E, Martin RK, Eldridge V, El-Khoury G. Hamstring control and the unstable anterior cruciate ligament-deficient knee. Am J Sports Med. 1985 Jan-Feb;13(1):34-9. DOI: 10.1177/036354658501300106

- Wellsandt E, Failla MJ, Snyder-Mackler L. Limb Symmetry Indexes Can Overestimate Knee Function After Anterior Cruciate Ligament Injury. J Orthop Sports Phys Ther. 2017 May;47(5):334-338. doi: 10.2519/jospt.2017.7285. Epub 2017 Mar 29. 
- Wilk KE, Romaniello WT, Soscia SM, Arrigo CA, Andrews JR. The relationship between subjective knee scores, isokinetic testing, and functional testing in the ACL-reconstructed knee. J Orthop Sports Phys Ther. 1994 Aug;20(2):60-73.

- Wright, Rick \& Magnussen, Robert \& Dunn, Warren \& Spindler, Kurt. Ipsilateral Graft and Contralateral ACL Rupture at Five Years or More Following ACL Reconstruction A Systematic Review. The Journal of bone and joint surgery. American volume. 2011; 93. 1159-65. 10.2106/JBJS.J.00898.

- Wu B, Zheng S, Cai ZH, Wang YL, Zeng M. [Case-control study on the effect of core strength training on the function of anterior cruciate ligament reconstruction]. [Article in Chinese]. Zhongguo Gu Shang. 2017 Aug 25;30(8):716-720. doi: 10.3969/j.issn.1003-0034.2017.08.007.

- Xergia SA1, McClelland JA, Kvist J, Vasiliadis HS, Georgoulis AD. The influence of graft choice on isokinetic muscle strength 4-24 months after anterior cruciate ligament reconstruction. Knee Surg Sports Traumatol Arthrosc. 2011 May;19(5):768-80. doi: 10.1007/s00167-010-1357-0. Epub 2011 Jan 14.

- Yasuda K, Ohkoshi Y, Tanabe Y, Kaneda K. Quantitative evaluation of knee instability and muscle strength after anterior cruciate ligament reconstruction using patellar and quadriceps tendon. Am J Sports Med. 1992 Jul-Aug;20(4):471-5.

- ZEKCER, Ari; SILVA, Ricardo Soares da; CARNEIRO FILHO, Mario. Reconstrução anatômica do LCA com duplo feixe: primeiros 40 casos. Revista Brasileira de Ortopedia, 2011. 